\author{
Universidade de Brasília \\ Instituto de Ciências Humanas \\ Departamento de Pós-Graduação em Filosofia
}

\title{
ELEMENTOS PARA A REJEIÇÃO DA ÉTICA NA FILOSOFIA DE MARTIN HEIDEGGER
}

Contribuição para uma Metaética Fenomenológico-Existencial

\section{Rodrigo Costa Silva}

Brasília 
ELEMENTOS PARA A REJEIÇÃO DA ÉTICA NA FILOSOFIA DE MARTIN HEIDEGGER

Contribuição para uma Metaética Fenomenológico-Existencial

Autor: Rodrigo Costa Silva

Orientador: Prof. Julio Cabrera.

2015 
RESUMO: Esta dissertação tem por objetivo mostrar como as éticas da tradição filosófica europeia são rejeitadas pelos elementos filosóficos de Ser e Tempo de Heidegger, especialmente três: ontologia fenomenológica, as noções de Dasein e de temporalidade originária. A análise da rejeição da ética tradicional pela filosofia de $\mathrm{Ser}$ e Tempo foi denominada Metaética heideggeriana, sendo o termo "metaética" empregado em um sentido mais abrangente, qual seja o de qualquer problematização filosófica acerca da ética. Para a análise metaética, partimos de uma exposição de diversos elementos fundamentais das éticas tradicionais para, num segundo momento, mostrarmos como eles são rejeitados pelo pensamento expresso em Ser e Tempo. Por fim, esboçamos teses metaéticas com o intuito de explicitar as razões pelas quais a ética em sentido tradicional é rejeitada.

PALAVRAS-CHAVES: Heidegger; Ética; Metaética; Ontologia Fundamental; Dasein; Temporalidade.

ABSTRACT: This work aims to show how the ethical theories from the European philosophical tradition are rejected by the force of three basics philosophical elements from Heidegger's Being and Time: the phenomenological ontology, the concept of Dasein and the concept of proper temporality. The analysis of this rejection is what we called a Heideggerian Metaethics (taken in a large sense of any critical philosophical approach to ethics). We start with an exposition of some basic elements from traditional ethical theories; secondly, a functional exposition of Heidegger's existential philosophy as exposed in Being and Time; and finally, we formulate some metaethical theses in order to clarify how traditional ethics is rejected by these Heideggerian existential elements.

KEY-WORDS:_Heidegger; Ethics; Metaethics; Fundamental Ontology; Dasein; Temporality. 


\section{ÍNDICE}

Introdução. O sentido da Ética na filosofia existenciária de Heidegger

Capítulo 1. Teorias éticas europeias tradicionais: uma breve exposição das suas particularidades e tendências..

Capítulo 2. Ser e Tempo de Heidegger: elementos existenciários para a rejeição da ética tradicional (Ontologia fenomenológica, Dasein, Temporalidade) .50

Capítulo 3. Esboço de uma Metaética heideggeriana. .93

Conclusões. 139

Apêndice. Poderia uma ética não tradicional evitar a rejeição radical das éticas tradicionais? A ética da afirmação da vida em Friedrich Nietzsche. 143

Bibliografia 154 


\section{INTRODUCÃO}

\section{O sentido da Ética na filosofia existenciária de Heidegger}

O presente trabalho parte da aceitação da tese de que não existe uma ética em sentido tradicional na filosofia de Ser e Tempo de Martin Heidegger. Essa tese não é uma novidade. O próprio Heidegger menciona a demanda de seus leitores por uma ética, como se fosse um pedaço que "faltasse" ao seu pensamento, e explica por que ela não seria necessária ${ }^{1}$. Assim, não se pergunta neste trabalho pela possibilidade da ética (possibilidade essa desde já descartada), mas pelo sentido de ética pressuposto por Heidegger para que ela não exista em seu pensamento ontológico-existenciário. A própria constituição da filosofia de Ser e Tempo traz elementos que fazem com que a ética, tal como as desenvolvidas ao longo da filosofia europeia anterior a Heidegger, não venha a ser. O conjunto desses elementos constitui o que denominaremos uma Metaética heideggeriana, cuja formulação pretende ser realizada neste trabalho, pelo menos em esboço.

Há de se esclarecer, no entanto, o que queremos dizer com o termo "metaética" no contexto deste trabalho. O termo aparece na Filosofia Analítica, na qual é entendido como uma das subdivisões mais gerais da Ética, ao lado da Ética Descritiva (descrição dos valores, normas, comportamentos de um povo ou grupo social) e da Ética Normativa (as diversas éticas particulares, que buscam determinar quais valores, ações ou modos de vida devem considerar-se corretos, bons, justos etc.). O filósofo Alfred J. Ayer traz à tona esse termo em fins dos anos 1940 para designar os estudos acerca da ética que se realizavam no âmbito da Filosofia Analítica. Nesse período, essa corrente de pensamento acreditava que muitos dos tradicionais problemas da história da filosofia foram equívocos linguísticos, que poderiam ser resolvidos ou dissolvidos numa análise da linguagem. Nessa linha, a investigação ética analítica investigava termos morais, tais como "bom" e "correto", procurando entender o funcionamento da linguagem e do raciocínio morais ${ }^{2}$.

Essa análise dos termos morais aponta para uma importante distinção da Metaética analítica a respeito da Ética normativa (que chamaremos simplesmente de

\footnotetext{
${ }^{1}$ HEIDEGGER Martin. Carta sobre o Humanismo. Rio de Janeiro: Tempo Brasileiro, 2009, p. 83.

2 NERI, Demetrio. Filosofia Moral. São Paulo, Edições Loyola, 2004, p. 35.
} 
ética): enquanto esta é de primeira ordem, a Metaética é de segunda ordem. Nas éticas, procura-se pensar e determinar se certos valores, ações, pessoas são corretos ou incorretos, justos ou injustos, bons ou maus; são preocupações que se encontram $n a$ ética. A Metaética, por seu turno, discorre sobre a ética; estuda-se descritivamente o discurso e a prática éticos, examinando seus termos e suas funções ${ }^{3}$, estando, assim, em um segundo nível de investigação. Por exemplo, enquanto uma ética particular pode prescrever como correto ser solidário com os outros, a Metaética investigaria se podemos determinar o que é o correto, o que significa ser "solidário" ou a relação entre conhecimento do que é correto e o agir corretamente (se é possível conhecer o que é correto, se esse conhecimento do correto implica agir corretamente, etc.).

As investigações metaéticas são distribuídas em diferentes âmbitos da filosofia, tais como a filosofia da linguagem (que investiga os valores de verdade de uma proposição ética, ou se ela tem algum sentido referencial), a filosofia da mente (que se pergunta se há uma disposição para o agir eticamente ou uma percepção de fato moral), a epistemologia (se é possível conhecer o bom, o correto; se concerne à moralidade o conhecimento, a verdade, a justificação ou se a ética é uma questão de intuição moral e não de conhecimento), entre outros problemas ${ }^{4}$.

Podemos notar que o interesse metaético é eminentemente teórico, um estudo dos elementos que concernem à moralidade, ao passo que as éticas têm um fim prático, no sentido de como agir com justiça ou corretamente, como promover a autorrealização humana, um bom convívio etc. A metaética e a ética, embora distinguíveis, não necessariamente estão afastadas. Ao longo da história da filosofia europeia, pensadores e formuladores de éticas se puseram questões que hoje consideraríamos como metaéticas. Um pensador clássico e que visivelmente já pensava em questões do significado dos termos morais foi Sócrates, pelo menos como nos mostram os diálogos de Platão, sempre se questionando sobre o que é o bem ou sobre se podemos aprender a ser virtuosos, etc. Isso pode nos indicar que, desde seus princípios, estiveram presentes na história da filosofia europeia investigações metaéticas avant la lettre ${ }^{5}$. No entanto, é

\footnotetext{
${ }^{3}$ MENDONÇA, Wilson. Questões metaéticas em: TORRES, João C. B. (org.). Manual de Ética. Questões de ética teórica e aplicada. Petrópolis: Vozes; Caxias do Sul: Universidade de Caxias do Sul; Rio de Janeiro: BNDES, 2014, p. 153.

${ }^{4}$ Ibidem, p. 158-159.

${ }^{5}$ NERI, Demetrio. Op. cit., p. 36.
} 
no século XX que a metaética se apresenta enquanto uma disciplina "relativamente autônoma, um debate organizado em que explicações dos aspectos centrais do discurso e da prática da ética são formuladas, criticadas e reformuladas" ${ }^{\prime 6}$, aplicando os métodos de análise estabelecidos nas investigações da filosofia da linguagem, epistemologia, metafísica, etc. da tradição da filosofia analítica. Todavia, enquanto essa passagem pelos questionamentos metaéticos foi importante para alguns autores clássicos para os fins práticos de suas éticas, na filosofia a metaética surge numa atitude que buscava ser mais neutra, investigando os termos morais sem aderir a alguma moralidade que seja ${ }^{7}$. Além disso, muitas investigações metaéticas hodiernas se realizam independentemente de alguma possível relevância ou irrelevância para a ética. É uma investigação pelo interesse filosófico que ela suscita, mesmo que em nada contribua para a prática ética efetiva $^{8}$.

Em suma, a metaética analítica é uma investigação filosófica que analisa os termos morais presentes nas éticas. Enquanto estas têm um interesse prático, procurando determinar e prescrever atitudes e valores, a metaética é um discurso de segunda ordem, ou seja, um discurso acerca da ética, investigando suas noções com fins teóricos. É importante determinar essas características gerais da metaética analítica para podermos esclarecer o que entenderemos por uma metaética heideggeriana. Para isso, adotamos uma noção alargada de metaética, que consiste em qualquer reflexão filosófica acerca da ética, de sua natureza e elementos, e inclusive com o poder de problematizar a própria existência da moralidade ${ }^{9}$, em vez de tomar a existência das éticas como um dado, como o faz a filosofia analítica. Numa metaética heideggeriana, como veremos, a própria existência das éticas que analisaremos está em questão desde o início.

No desenvolvimento de uma metaética heideggeriana, no caso, perguntaremos como e por que não existe nem pode existir uma ética, em sentido tradicional, quando assumimos e utilizamos os elementos existenciários e ontológicos retirados do pensamento de Ser e Tempo. Como se questiona a própria existência de uma ética como as tradicionais em Ser e Tempo, a metaética não pode ser como a da filosofia analítica,

\footnotetext{
${ }^{6}$ MENDONÇA, Wilson. Op. cit., p. 155.

${ }^{7}$ NERI, Demetrio. Op. cit., p. 36.

${ }^{8}$ MENDONÇA, Wilson. Op. cit., p. 153-154.

9 A reflexão de Nietzsche sobre ética, por exemplo - se considerada como metaética - afirma a inexistência de fatos morais.
} 
que pressupõe sua existência. A metaética tem de ser de outro tipo. Nem tal metaética seria uma análise teórica, pois que em Heidegger não faz sentido a distinção entre teoria e prática, já que a noção de existência na filosofia de Ser e Tempo de Heidegger, fundamental para a exclusão da ética tradicional, como será visto, antecede e dissolve tal distinção. Tratar-se-á de uma metaética fenomenológico-existenciária, na qual a ética tradicional é problematizada em seu próprio ser. Numa metaética heideggeriana, procuraremos explicitar como a ontologia fundamental elimina a ética, em sua noção tradicional, não por esta não ter sido desenvolvida pelo filósofo por alguma eventualidade, mas porque a própria constituição do pensamento de Ser e Tempo a bloqueia.

Para a formulação desta metaética, é preciso perguntarmos qual é a compreensão implícita de ética que está por trás da sua exclusão ontológico-existenciária. A resposta ao sentido pressuposto por Heidegger se encontra na própria tradição filosófica europeia. Heidegger dialoga em todo o momento com a história da filosofia europeia, ignorando outras tradições. Assim, quando descarta a ética, Heidegger tem em mente uma noção de ética tal como formulada ao longo dessa tradição, que estamos qualificando como tradicional. No entanto, talvez uma definição geral da ética tradicional seja inviável pela variedade de concepções de ética formuladas ao longo do pensamento filosófico europeu. No decorrer dessa história, houve várias e distintas correntes éticas, que sustentaram concepções diversas e mesmo conflitantes, teorias que detinham compreensões variadas de ética, de seu caráter, propósitos e possibilidades. Tudo isso dificultaria, a princípio, utilizar para o nosso estudo metaético heideggeriano uma concepção geral e única do que seja ética; e, suposto que exista ou seja possível essa noção geral, poder-se-ia perder de vista elementos importantes próprios de cada corrente ética particular. $O$ que se pode esperar de uma ética pode variar muito dependendo de qual ética particular estivermos falando. Assim, procuraremos trazer diversas formulações éticas da filosofia europeia que Heidegger, como grande conhecedor dessa tradição, deve ter em mente ao ignorar a ética tal como entendida ao longo da tradição filosófica com que defronta.

Por isso, uma questão fundamental em nosso trabalho consistirá em perguntarmos se a radicalidade da exclusão das éticas tradicionais no pensamento de Heidegger deve levar em conta ou não as peculiaridades de cada teoria ética em particular. Na verdade, 
melhor que o termo exclusão, deveríamos utilizar o termo rejeição, porque Heidegger não se demora em discutir com as teorias éticas, senão que os elementos da sua ontologia fundamental simplesmente não permitem formular uma ética em sentido tradicional, rejeitam-na como se fosse um corpo estranho. O ponto que procuraremos investigar neste trabalho é se, a despeito das particularidades de cada teoria ética, a própria constituição do filosofar heideggeriano rejeita, nesse sentido, todas as teorias éticas concebidas ao longo da história da filosofia europeia, de Aristóteles a Max Scheler, aquilo que chamaremos de éticas tradicionais.

Nosso trabalho, portanto, consiste no confronto entre a filosofia de Ser e Tempo de Heidegger com as éticas que denominamos tradicionais, ou seja, éticas desenvolvidas ao longo da tradição filosófica europeia, com a qual Heidegger debate. "Ética tradicional" refere-se à noção de ética que Heidegger recusaria ao comentar a demanda por uma ética em seu pensamento. "Ética", assim como "lógica" ou "física", explica o filósofo, não aparecem nesses termos antes da escola de Platão. Nem eram necessários, os pensadores de antes "não conheciam nem 'lógica' nem 'ética' nem 'física", no entanto, seus pensamentos não eram "nem ilógicos nem imoral"10. Assim, eles podem não ter conhecido a "ética" enquanto disciplina filosófica, mas tinham um ethos mais originário, com o qual Heidegger, o pensador do originário, simpatiza. Pode-se ainda procurar pensar uma espécie de ética em Heidegger, um ethos originário, mas certamente ela se distanciaria do pensamento ético desenvolvido na tradição filosófica. O nosso trabalho, por seu turno, consiste justamente em mostrar como a ética tradicional é rejeitada pelo pensamento de Ser e Tempo. Não está em questão neste trabalho, portanto, se é possível pensar em uma espécie de ética ou um ethos originário no pensamento de Heidegger ${ }^{11}$, profundamente distinto do pensamento ético da tradição; e sim, focando-nos na filosofia de Ser e Tempo, trazer os elementos que fazem com que a ética, ao menos em sentido tradicional, seja rejeitada. Queremos defender, portanto, que as éticas tradicionais são eliminadas, como que espontaneamente, do pensamento expresso em Ser e Tempo.

\footnotetext{
${ }^{10}$ HEIDEGGER Martin. Carta sobre o Humanismo. Op. cit., p. 85.

${ }^{11}$ Já existem trabalhos que buscam pensar uma ética em Heidegger (ver: LOPARIC, Zeljko. Ética e Finitude. São Paulo: Editora Escuta, 2004; Sobre a responsabilidade. Porto Alegre: EDIPUCRS, 2003; HODGE, Joanna. Heidegger e a ética. Trad. Gonçalo Couceiro Cruz. Lisboa: Instituto Piaget, 2000).
} 
Entretanto, para mostrar essa tese, precisaremos apresentar quais são alguns dos elementos peculiares de cada teoria ética tradicional, para que se possa entender se as características mais específicas de cada ética são determinantes ou não para a sua rejeição ontológico-existenciária. Teremos, assim, de expor novamente algumas dessas teorias éticas tradicionais mais significativas. Aqui não poderíamos analisar em detalhe cada teoria ética surgida na filosofia europeia; contudo, passaremos por teorias e autores clássicos, embora isso inclua tanto aqueles com que Heidegger constantemente dialoga em suas obras e outros pouco ou mesmo nunca mencionados por ele. A exposição e a justificativa da escolha das teorias éticas serão realizadas no capítulo 1 deste trabalho.

Após a exposição sumária e funcional das principais teorias éticas tradicionais, estudaremos de que forma elas não fazem sentido a partir da analítica existenciária de Heidegger, em virtude de diversos elementos extraídos de Ser e Tempo, especialmente três:

(1) A sua particular apropriação da fenomenologia de Edmund Husserl e sua aplicação à ontologia.

(2) A sua concepção do humano como Dasein.

(3) A sua ideia de uma temporalidade originária da existência, diferente da temporalidade vulgar.

Assim, o presente trabalho seguirá, aproximadamente, o seguinte roteiro:

Capítulo 1. Teorias éticas europeias tradicionais: uma breve exposição das suas particularidades e tendências.

Capítulo 2. Ser e Tempo de Heidegger: elementos existenciários (Ontologia fenomenológica, Dasein, Temporalidade).

Capítulo 3. Esboço de uma Metaética heideggeriana.

Conclusões

Apêndice: Poderia uma ética não tradicional evitar a rejeição radical das éticas? A ética da afirmação da vida em Friedrich Nietzsche. 


\section{CAPÍTULO 1.}

\section{Teorias éticas europeias tradicionais: uma breve exposição de suas particularidades e tendências.}

No presente capítulo, apresentaremos algo já muito conhecido para o leitor de filosofia, mas que precisaremos para levar adiante o nosso trabalho. Será feita uma breve exposição das mais destacadas teorias éticas surgidas no pensamento europeu ao longo dos séculos, a que chamamos éticas tradicionais. Não faremos aqui exposições exaustivas dessas teorias, mas destacaremos delas somente aqueles elementos estritamente necessários para mostrar a atitude de Heidegger a respeito da ética tradicional em geral, e de alguns conceitos característicos dessas teorias, tais como virtude, dever, valores, contrato, felicidade, etc. A partir dessa exposição estritamente funcional das teorias éticas, esperamos ganhar subsídios para, num segundo momento, entender de que maneira e com quais suportes filosóficos essas teorias são rejeitadas da ontologia fenomenológica de Ser e Tempo, e se essa rejeição se produz de uma maneira geral ou em virtude de características mais específicas dessas teorias.

Os autores clássicos que escolhemos para exposição são: Aristóteles, Hobbes, Hume, Kant, Stuart Mill, Max Scheler, além de outros autores com menor enfoque, como Epicuro, Hegel e Schopenhauer. A exposição não exaustiva desses autores tem por objetivo apresentar somente alguns elementos fundamentais de suas teorias. É por essa razão, por exemplo, que Max Scheler, autor possivelmente presente para Heidegger como pensador fenomenológico, aparece logo na primeira seção, "Eudemonia e Virtudes", para mostrarmos pontos do que o autor afirma acerca das virtudes, e reaparece mais tarde entre os pensadores que estão em diálogo com Kant, como Hegel e Schopenhauer.

É possível que essas escolhas sigam, até certo ponto, a exposição das teorias éticas clássicas segundo uma divisão corriqueira na Filosofia Analítica: éticas das virtudes ou eudemônicas (que estudam o papel das virtudes na ação e a busca de autorrealização do ser humano), éticas contratualistas (que focam os acordos hipotéticos que estipulam normas a serem seguidas pelos homens em vista do bem-estar de uma sociedade), éticas do senso moral (que estudam os vícios e as virtudes percebidos por 
uma espécie de sentido moral, em vez de definidos pela razão), éticas deontológicas (que colocam o acento nos deveres de um sujeito racional), e éticas utilitaristas (que focam as consequências das ações, visando à maximização do bem-estar). Essas teorias são representadas respectivamente por Aristóteles, Hobbes, Hume, Kant e Stuart Mill, autores que exporemos com melhor detalhamento. O problema que pode surgir com essa divisão de teorias mais própria da Filosofia Analítica é que fiquemos numa tradição distante da linha de Heidegger, o que pode parecer que não condiz com o propósito central do nosso trabalho, o estudo da rejeição heideggeriana da ética. Cabe, pois, uma breve justificativa da nossa escolha de teorias éticas.

Já no início de nosso trabalho vemos que há um certo diálogo com a Filosofia Analítica, na medida em que adotamos um termo próprio de sua tradição, qual seja "Metaética". Como mostramos anteriormente, a metaética foi sistematizada como um âmbito de investigação filosófica autônomo nessa tradição anglo-saxã, embora ao longo da história da filosofia já se tenha realizado investigações acerca dos termos da ética que chamaríamos hoje de metaéticas. Nós modificamos o sentido desse termo para os fins de nosso trabalho, fazendo brotar do pensamento heideggeriano algo que ele próprio não realizou literalmente em seus textos: uma metaética fenomenológico-existenciária, que apresenta os elementos para a rejeição da ética em sentido tradicional (tal como presente nos autores mencionados). Se já desde o início há essa espécie de diálogo com a Filosofia Analítica ao adotarmos o termo "metaética" para nosso trabalho (mesmo que expandido), parece não haver inconvenientes em concebermos uma metaética fenomenológico-existenciária em referência precisamente a essas teorias éticas tal como classificadas por essa corrente filosófica anglo-saxã, às quais se referem as suas próprias análises metaéticas.

Todavia, mesmo se seguíssemos a atual cultura filosófica de separar o que é próprio da Filosofia Analítica e o da chamada "Filosofia Continental" (da qual Heidegger é considerado um dos principais expoentes), verificaríamos que os mesmos autores mencionados poderiam ser utilizados. Aristóteles, Kant, Hume, Stuart Mill, Hobbes são considerados clássicos, e suas noções de virtude, eudemonia, contrato, pessoa, dever, bem-estar etc. são objeto de discussão de ambas as tradições analíticas e "continentais", de modo que essa distinção não é fundamental no que tange à classificação de teorias éticas. 
Há mais um outro aparente problema. Alguns desses autores, como Aristóteles e Kant, estão entre aqueles com os quais Heidegger constantemente dialoga em seus textos, enquanto outros (como Hume, Hobbes e Stuart Mill) são pouco ou sequer mencionados pelo filósofo. Assim, poder-se-ia argumentar que essas teorias apresentadas não seriam as que Heidegger levaria em consideração se ele mesmo tivesse empreendido a tarefa metaética. No entanto, não discutido não significa desconhecido. Embora Heidegger não se refira explicitamente a esses autores, ele não os ignorava, pois são clássicos da história da filosofia europeia que nosso filósofo conhecia perfeitamente. O silêncio diante de certos autores - como os empiristas britânicos pode apontar mais para o pouco interesse filosófico que seus pensamentos despertavam em Heidegger, de tal forma que seu silêncio já indica um posicionamento filosófico diante dessas teorias, não um mero deixar de discutir. A sua omissão pode indicar como os elementos constituintes das teorias éticas desses autores são rejeitados pela ontologia fundamental de Heidegger.

Empreenderemos, então, à nossa exposição das teorias éticas tradicionais assim classificadas procurando apresentar seus elementos fundamentais, mas sem adentrar em detalhes, tanto no caso de autores sempre próximos ao trabalho de Heidegger, como Aristóteles e Kant, quanto de outros que menciona pouco, como Scheler, ou mesmo que quase não menciona, como Stuart Mill, Hobbes e Schopenhauer, para tentar mostrar como essas diferentes teorias éticas tradicionais, que variam quanto a propósitos e conceitos fundamentais, ficam, apesar dessas diferenças, como que expulsas da filosofia da existência de Heidegger pela força a constituição de seu pensamento expresso em Ser e Tempo.

\section{1. Éticas da eudemonia e das virtudes}

Aristóteles é o filósofo clássico que habitualmente se escolhe como paradigma da Ética das Virtudes. Não só foi um dos primeiros autores que sistematizaram uma ética, como foi bastante influente no período antigo e é hoje o mais presente na retomada 
contemporânea da Ética das Virtudes ${ }^{12}$. Sua ética é costumeiramente nomeada como Ética Eudemônica, pela noção de Eudaimonia (felicidade ou boa-venturança), que orienta o seu pensamento moral e também uma boa parte da moral antiga greco-romana. Ela aparece em Aristóteles como resposta à pergunta pelo que seria o fim do ser humano. Para o estagirita, toda ação, toda atividade, toda investigação e toda arte, em suma, tudo tem um bem ao qual tende. Tudo tem um bem, que é seu fim - télos. Como há diversas atividades, ações e coisas, há também diversos modos de fins; como exemplifica o filósofo, o fim da medicina é a saúde, o da construção naval é um navio e o da guerra é a vitória. Aristóteles classifica-os em fins intermediários e fins últimos. Os fins intermediários são aqueles que se desejam em vista de outro fim, enquanto os fins últimos são aqueles desejados por si mesmos. No entanto, apesar dessa separação entre fins intermediários e últimos, mesmo estes, fins ou bens em si mesmos, podem ser fins para outros fins. Por exemplo, o conhecimento, o prazer e as virtudes são bens em si próprios, sendo que podem ser direcionados a outro fim (como o conhecimento matemático para construção de um edifício). No contexto ético, as virtudes são bens em si, mas são importantes para o fim do ser humano, que é a felicidade.

Ora, mas como Aristóteles chegou à conclusão de que a felicidade seria o fim próprio ao humano? O filósofo procura saber sobre o que seria o supremo bem, aquele cujo fim é em si próprio, sem ser intermédio a nenhum outro bem. Primeiro, o filósofo recorre à opinião geral sobre o assunto na busca por saber qual é o sumo bem a que uma ação pode levar, o fim último. De acordo com a opinião geral, a felicidade é o bem supremo. Porém, não há consenso sobre aquilo em que ela consiste. $\mathrm{Na}$ opinião da maioria dos homens, assim como também na das pessoas mais "vulgares", e a julgar pelo modo de vida que levam, a felicidade está no prazer, na vida de gozos ${ }^{13}$. Já para pessoas mais "sofisticadas", esse bem é a honra, pois que é a finalidade da vida dedicada à política ${ }^{14}$. Vemos que Aristóteles analisa as opiniões a partir de determinados modos de vida. Falamos da vida de gozos e da vida política, mas há também a vida contemplativa e a vida de ganho, busca de riqueza. Isso aponta para uma

12 SLOTE, Michael. Virtues Ethicsem: SKORUPSKI, John (Ed) The Routledge Companion to Ethics.Nova Iorque, Routledge, 2010, p. 481.

13 ARISTÓTELES. Ética a Nicômaco. Trad. António de Castro Caeiro. São Paulo: Atlas, 2009, p. 21 (1905b).

${ }^{14}$ Idem. 
característica da ética das virtudes antiga: trata-se de um modo de ser; não se busca a forma correta de ação, mas uma forma de vida.

A breve análise da opinião geral e das relações com modos de vida, que Aristóteles realiza na seção V do livro I da Ética a Nicômaco, não aponta para uma resposta, apesar de problematizar algumas dessas noções de felicidade, como a da honra $^{15}$. Então, o filósofo peripatético procura outra via: uma melhor análise da noção de bem. Na seção VII, retoma a ideia de que as diferentes ações, artes, etc. têm um bem, o qual se mostra diverso. O bem é o fim ao qual se visa quando se realiza algo. Como os fins são vários, nem todos atingem uma completude absoluta. $\mathrm{O}$ que se procura em seu texto é o fim supremo (como completude), e se houver mais de um, o mais completo entre todos. Aqueles bens que são desejáveis por si mesmos são mais completos que os desejáveis em vista de outra coisa, assim como os que são desejáveis tanto em si mesmos como também por outro são menos completos que os bens que se desejam somente por si próprios; "simplesmente completo é aquele fim que é sempre escolhido segundo si próprio e nunca como meio em vista de qualquer outro". Ora, isso é o modo como conceituamos a felicidade, segundo Aristóteles. Numa palavra, a felicidade é aquilo que se conceitua como simplesmente completo, fim em si mesmo.

\footnotetext{
De fato, nós escolhemos sempre a felicidade por causa dela mesma, e nunca em vista de outro fim para além dela. Escolhemos também a honra e o prazer, o poder da compreensão e toda a excelência [areté]. Em primeiro lugar, em vista de si próprios (isto é, não escolhemos cada um desses fins por causa de nada que daí possa resultar); em segundo lugar, em vista da própria felicidade, porque supomos que, uma vez obtida, seremos felizes. Mas ninguém escolhe a felicidade em vista daqueles fins, nem, em geral, em vista de qualquer outro fim, seja ele qual for. ${ }^{16}$
}

A autossuficiência, "bastar-se a si próprio""17, outra característica do supremo bem, é também entendida de acordo com o modo em que se entende a felicidade. A autossuficiência, como o termo pode nos indicar atualmente, não significa isolamento, um bastar-se a si mesmo solitário, mas a vida com a família, amigos e concidadãos,

\footnotetext{
${ }^{15}$ Ibidem, p. 21-22 (1905b - 1906a).

${ }^{16}$ Ibidem, p. 26 (1907b).

${ }^{17}$ Idem.
} 
porque, no entender do estagirita, o ser humano "está destinado, pela sua natureza, a existir em comunhão com os outros" ${ }^{\text {18 }}$. Ou seja, há uma base social necessária para a felicidade, e isso está conforme ao que Aristóteles afirmará mais à frente, que a felicidade, o bom viver, está também na vida em comunidade, o que casa a ética com a política.

Então, até agora, a felicidade é vista como absoluta, autossuficiente e fim da ação, porém, afirma Aristóteles, ainda há de explicar o que ela é. Para tanto, o filósofo questiona-se sobre a função (ergon) do ser humano. Ora, das coisas e atividades, o bem reside em sua função; e assim também será no caso do homem, se lhe houver alguma função. Para chegar ao que seria tal função, pergunta-se sobre o que é peculiar ao humano. E o que caracteriza o ser humano, no ver de Aristóteles, é seu lado racional. A vida nutritiva, nutrir-se e crescer, também a têm as plantas, portanto não lhe é único. A vida da percepção o homem compartilha com os animais. É a vida ativa, aquela com o elemento racional, o que lhe é próprio. A função do homem é uma atividade da alma que traz um princípio raciona $1^{19}$. Assim, análogo ao caso do flautista, cuja função é tocar a flauta, e do bom flautista, que tem como função tocá-la bem, a função do homem está em sua vida racional, e a do bom homem está em uma boa realização da vida racional.

Já sabemos, então, embora não de modo esmiuçado, que para Aristóteles a função do ser humano está na vida constituída por atividades e ações segundo um princípio racional. De fato, Aristóteles procura caracterizar um modo de vida, aquele que se pode dizer feliz, eudemônico; e o sentido de sua ética seria, como podemos dizer, um bem viver. Isso traz a tona um ponto importante que distingue a moral antiga da moral moderna. Como a moral antiga coloca o acento na via para a felicidade, como vemos em Aristóteles, não the faz sentido a noção de obrigação, bem própria da moral moderna. A moral antiga se nutre de conselhos e de exemplos de indivíduos que teriam essa vida feliz, em suma, uma orientação na busca da felicidade, coincidente com a vida moral; mas não traz mandamentos ou obrigações, pois que seria um tanto absurdo e irrelevante obrigar o indivíduo a agir em prol do que lhe é uma vantagem - a felicidade. Por outro lado, na moral moderna, influenciada pelo cristianismo, que separa a

\footnotetext{
${ }^{18}$ Idem.

${ }^{19}$ Ibidem, p. 27 (1098a).
} 
felicidade da vida terrena, sendo esta um "mar de lágrimas", há a necessidade de um artifício como a obrigação para levar a agir eticamente ${ }^{20}$, como veremos nas análises das teorias de Hobbes e de Kant.

Na busca do bom viver, o que caracteriza a ética eudemônica, própria aos antigos, as virtudes têm uma papel de destaque. O termo grego para virtude é areté, também traduzido como excelência ${ }^{21}$. Os dois termos, "virtude" e "excelência", têm certo vínculo. "Virtude" vem de virtus, tradução latina de areté. E areté significa a excelência própria de $\operatorname{algo}^{22}$. Assim, a excelência de uma vassoura é varrer bem; de uma mesa, dar um bom apoio. Qual seria então a excelência de um ser humano? Para Aristóteles, as virtudes têm a ver com a alma humana. No entanto, a nossa alma pode ser tripartida entre a vegetativa (que concerne à nutrição e ao crescimento), a apetitiva e sensitiva (relacionada a emoções e desejos), e a propriamente racional. Apesar dessa distinção, a parte apetitiva da alma pode ter certa relação com a razão, na medida em que é influenciada e pode ser guiada por ela. Como há essas duas formas de a alma se ligar com a razão, a parte estritamente racional e a apetitiva, que pode se orientar pela razão, Aristóteles divide as virtudes também em duas formas: as virtudes éticas e as virtudes teóricas.

À parte apetitiva e sensitiva da alma, que diz respeito aos desejos e sentimentos do ser humano, estão vinculadas as virtudes éticas. Essa parte da alma está relacionada com a razão na medida em que pode ser influenciada por ela; ou seja, os sentimentos e desejos podem ter orientação da razão. As virtudes éticas consistem, então, na moderação desses apetites e emoções pela razão. Segundo Aristóteles, as virtudes não são inatas; as virtudes teóricas advêm fundamentalmente do ensino, algo que demanda tempo, enquanto as virtudes éticas formam-se no indivíduo através do hábito. Assim como nas perícias, em que é preciso prática para tornar-se excelente (um bom tocador de instrumento musical necessita treinar bastante), um indivíduo devém virtuoso na medida em que pratica ações virtuosas: torna-se justo através de práticas justas, honesto agindo honestamente, temperado agindo com temperança. Por isso, há a importância da

\footnotetext{
${ }^{20}$ BROCHARD, Victor. A Moral Antiga e a Moral Moderna. Em: Cadernos de Ética e Politica 8, 1/2006, p. 135-136.

${ }^{21}$ Usamos "virtude" e "excelência" como sinônimos na exposição sobre Aristóteles.

${ }^{22}$ COMTE-SPONVILlE, André. Pequeno Tratado das Grandes Virtudes. São Paulo: Martins Fontes, 2012, p. 8.
} 
educação para formar o indivíduo virtuoso e, no âmbito político, boas leis para que com o tempo as pessoas passem a serem boas cidadãs ${ }^{23}$.

Mas em que consistem as virtudes éticas? A virtude está na justa medida entre o excesso e a falta, que caracteriza os vícios. Justa medida, no entanto, não significa a metade aritmética. Por exemplo, uma determinada quantidade de comida pode ser excessiva para o humano, enquanto outra excessivamente escassa. Porém, não quer dizer que se deva comer exatamente a quantidade média dessas duas medidas; ela pode ser uma quantidade boa para alguns, mas ruim para outros. Um atleta tem de se alimentar bastante, pois a atividade esportiva consome muita energia de seu corpo; ao passo que um artesão precisa consumir menos alimento. "O meio procurado não é o meio absoluto da coisa em si, mas o meio da coisa relativamente a cada um" ${ }^{24}$. No caso das virtudes éticas, busca-se o justo meio entre o excesso e a falta com respeito às emoções e ações. A coragem é a justa medida entre a covardia e a temeridade; o covarde é sem ação, deixa de realizar as coisas e a si mesmo por puro medo; por seu turno, aquele que tem o vício da temeridade dispõe-se a tudo, atira-se nas situações de modo inconsequente, o que leva perigo aos outros e a si próprio; ter coragem, então, seria ter a disposição para enfrentar as situações, mas com cautela.

As virtudes teóricas, como dissemos, concernem ao lado estritamente racional da alma; esse lado, porém, ainda pode ser dividido em duas partes, uma que dá conta dos entes necessários e eternos, e outra dos ligados à contingência. A excelência típica da primeira dessas duas partes é a sabedoria (sophia), enquanto a da outra é a sensatez (phrónesis). A sensatez consiste na capacidade de deliberar acerca do que é bom e mal ao ser humano nas circunstâncias que se apresentam ${ }^{25}$. Vemos que há certa ligação com a noção das virtudes éticas, a saber, do justo meio. A busca do justo meio é um princípio que guia as ações, saber aplicá-lo requer essa faculdade deliberativa, a sensatez. A vida virtuosa e a sensatez estão imbricadas, de modo que quem é virtuoso fatalmente é sensato, e do mesmo modo o contrário.

\footnotetext{
${ }^{23}$ ARISTÓTELES. Op. Cit., p. 40-41, [110314-1103b].

${ }^{24}$ Ibidem, p. 48, [1106b7].

${ }^{25}$ Ibidem, p. 133 [1140b].
} 
A sabedoria, por seu turno, é a virtude mais elevada, visto que, enquanto a sensatez se ocupa com a vida humana, ela se ocupa de questões mais estimadas, como os primeiros princípios. A sensatez versa sobre o que é mutável, das coisas que se apresentam na vida humana, situações particulares sobre as quais é preciso deliberar; ao passo que a sabedoria versa sobre o que é necessário e é o que se tem de mais estimado; e mesmo que o humano, objeto da sensatez, possa ser considerado o mais elevado dos seres vivos, há muito que é mais divino e esplendoroso que o ser humano ${ }^{26}$. A sabedoria e a sensatez, portanto, são virtudes distintas, de modo que um indivíduo pode ter uma sem ter a outra. Aristóteles menciona Anaxágoras e Tales, que seriam sábios, conheciam "coisas extraordinárias, espantosas, difíceis de aprender e divinas", sem, no entanto, serem sensatos, ou seja, desconheciam o que era bom ou ruim para suas vidas. Péricles, por seu turno, aparece como um indivíduo sensato, e Aristóteles o toma como exemplo ao afirmar a vinculação do saber deliberar com a sensatez ${ }^{27}$. A menção dessas pessoas é importante, sendo que é uma das características da ética das virtudes: há individuos exemplares, conhecidos por suas virtudes.

Que relação isso tudo tem a ver com a felicidade? Já há certos elementos que apontam para isso. Em primeiro lugar, Aristóteles afirma que o virtuoso sente-se bem com as virtudes, elas são aprazíveis por si próprias, de modo que o virtuoso não tem necessidade de prazeres adventícios. As pessoas percebem que um dos problemas de muitas das coisas agradáveis é que elas não são por sua natureza agradáveis em si, estando elas em conflito, ou seja, certos prazeres atrapalham outros. Esse problema não existe nas virtudes, visto que elas são aprazíveis em si mesmas; não encontramos um indivíduo de bem que não sinta prazer com ações nobres, por exemplo, um justo com relação às ações justas ${ }^{28}$. Isso aponta já para o vínculo que se tem da vida virtuosa com a felicidade, vínculo do qual já dissemos. Um segundo ponto está na sapiência com que o sensato lida com a fortuna. Muitos diriam que a felicidade está nas mãos da fortuna, que tanto pode propiciar uma boa vida quanto uma vida repleta de penúrias. Todavia, o sensato sabe lidar bem com as situações adversas, de modo que não fica inteiramente sujeito às imposições da fortuna. Como nos diz Epicuro a encontro de Aristóteles: "Raramente a sorte prejudica um homem sábio, pois as coisas principais e fundamentais

\footnotetext{
${ }^{26}$ Ibidem, p. 136 [1141b].

${ }^{27}$ Ibidem, p. 133 [1140b].

${ }^{28}$ Ibidem, p. 30 [1099a].
} 
sempre foram governadas pela razão, e por todo o curso da vida a razão as governa e governará."29

Vemos, então, como pode haver uma consonância entre a vida virtuosa e a felicidade. Todavia, ainda pode-se falar em uma plena realização da felicidade, ou melhor, de uma felicidade suprema. Sabemos que em Aristóteles a felicidade está na plena realização do que é próprio ao humano, qual seja, sua racionalidade. Porém, não há consenso se Aristóteles defende que a vida contemplativa, associada às virtudes teóricas, seja a vida superior, ou que é também necessária, para a plena felicidade, a vida condicionada pelas virtudes éticas. De qualquer modo, é a vida contemplativa o ápice da felicidade em Aristóteles, esta que se relaciona ao traço divino no humano, enquanto a vida ética relaciona-se à vida estritamente humana.

Do que foi mencionado da ética aristotélica, devemos salientar determinadas características. O ser humano aí tem uma natureza definida, de modo que a felicidade, fim da ética e do próprio ser humano, é consoante com a plena realização de sua natureza, a racionalidade. As virtudes, bens em si mesmas, não só compõem a vida feliz como orientam o indivíduo em seu viver. O sensato, ou virtuoso, tem a capacidade de deliberar sobre aquilo que é bom ou ruim nas vicissitudes da vida, ou seja, o bem agir. Em suma, é uma ética que tem bastante definidos a natureza e os desejos do ser humano e busca realizá-los.

Max Scheler, em seu ensaio Para a Reabilitação da Virtude, faz uma análise de duas virtudes específicas, a humildade e a veneração. Antes, contudo, procura explicar o que entende por virtude. Como o próprio título do ensaio já nos diz, o filósofo almeja reabilitar a noção de virtude, visto que seu sentido se modificou ${ }^{30}$. Segundo Scheler, a virtude tem a ver com um "brilho", como o de uma "pedra preciosa" que o virtuoso porta, ou seja, algo que notamos no virtuoso, qual uma luz que dele emana, e não como uma mera "habilidade" ou um "esforço penoso" que os outros não podem ver ${ }^{31}$. Ela, em sua antiga concepção, é uma qualidade da própria pessoa, que não tem sua razão de ser

\footnotetext{
${ }^{29}$ EPICURO, Máximas Principais, XVI, apud LAÊRTIOS, Diógenes. Vidas e Doutrinas dos Filósofos Ilustres. Brasília: Editora UnB, 2008, p. 317.

${ }^{30}$ SCHELER, Max. Para a Reabilitação da Virtude em: Da Reviravolta dos Valores. Trad. Marco Antônio Casanova, 2ed. Petrópolis: Vozes, 2012, p. 21.

${ }^{31}$ Idem.
} 
para uma serventia, e sim para ser uma "livre joia de seu portador" ${ }^{32}$; noutros termos, a utilidade não é seu fim, embora possa ser de fato útil, ela é antes uma qualidade de quem a possui. Esse sentido, segundo Scheler, se perdeu, sendo a virtude entendida nos últimos tempos enquanto uma habilidade adquirida pelo hábito, algo arduamente perseguido. Podemos entender isso que Max Scheler nos diz, por exemplo, quando estipulamos que há deveres ou princípios a serem seguidos e, na medida em que nos esforçamos para cumpri-los, eles se tornam hábitos e, só assim, mais facilmente realizáveis. Pelo contrário, de acordo com Scheler, a virtude, na verdade, é "a mais extrema antípoda do hábito"; é uma "consciência de poder e potência", ou seja, de capacidade e de força que o virtuoso tem. De modo que fazer o bem, para aquele que possui virtude, não é um trabalho árduo que o hábito atenua; somente a falta de virtude ou o vício faz com que o bem seja uma atividade penosa, pois que "a possessão da virtude empresta a toda boa lida a manifestação livremente esvoaçante de um pássaro gracioso",33, um movimento natural do virtuoso.

Algo que podemos salientar sobre as virtudes nesse texto de Max Scheler é no que diz respeito à intuição de valores. Assim como podemos intuir, por exemplo, as cores de um objeto, também intuímos originariamente seu valor. Uma árvore não só é esverdeada, áspera, dura, como também me aparece como bela, agradável, aconchegante. Nós, enquanto pessoas, podemos intuir esses valores, os quais podem ser divididos em uma hierarquia, que os distingue em prazerosos, úteis, culturais ou mesmo sacros. Há uma forma de intencionar os objetos que corresponde aos valores, que são os “atos do coração" ou "atos emocionais". Duas emoções básicas constituem esses atos: o amor e o ódio. Enquanto no amor o valor de um objeto se mostra de modo ascendente, elevado, no ódio ele aparece degradado ${ }^{34}$. Não só os valores podem ser intuídos, como existem diferentes modos de intenciona-los ou intuí-los, de sorte que os valores têm suas formas de visualização condicionadas a isso. Nessa linha de pensamento, as virtudes analisadas nesse texto de Scheler permitem que se intuam certos valores que, de outro modo, não seriam percebidos; elas são modos de visualização. Apresentaremos, brevemente, algumas das características dessas virtudes e sua relação com a intuição dos valores e com o mundo.

\footnotetext{
32 Ibidem, p. 23.

${ }^{33}$ Ibidem, p. 22.

${ }^{34}$ DAVIS, Zachary \& STEINBOCK, Anthony.Max Scheler.2014. Disponível em: http://plato.stanford.edu/entries/scheler/ Acessado em 30 de agosto de 2015.
} 
A primeira virtude sobre a qual Scheler disserta é a humildade, caracterizada assim: "é o pulsar interno e duradouro da disposição espiritual para o servir, no centro de nossa existência, da disposição para servir a todas as coisas, às boas e más, às belas e feias, às vivas e mortas" ${ }^{, 35}$. Essa virtude cristã se opõe ao orgulho; não àquele que temos por nossa posse, pelo que conquistamos, por nossa família etc., mas a esta outra modalidade que é diabólica: o "orgulho do valor moral próprio enquanto valor mais elevado" 36 . Enquanto na primeira modalidade vemos uma forma de amor que temos pelas coisas e pessoas de que nos orgulhamos, sendo assim que elas nos apresentam com um valor próprio, o orgulho por si mesmo passa por cima de todas as coisas e valores; o orgulhoso se desconecta do mundo. É um orgulho do "eu nu e esvaziado" e do desligamento com o mundo, "seu movimento descreve a direção exata que conduz para o seio disto que com razão os cristãos chamaram de 'inferno': o inferno próprio que é a não possessão do amor" ${ }^{37}$. A humildade, por sua vez, é uma modalidade do amor $^{38}$. Ela, ao contrário desse orgulho de si, abre os olhos para os valores do mundo; a humildade é um sentimento de rebaixamento diante do mundo, de modo que este aparece deslumbrante: um maravilhamento diante do mundo. Assim, a humildade "primeiramente parte do fato de não ser nenhum ganho, mas toda doação e maravilhamento, faz com que tudo ganhe" ${ }^{\text {"39. }}$.

A veneração, a segunda virtude analisada por Scheler, é um ver que enxerga além da imediatez das coisas: o seu "mistério" e a "profundeza de suas existências"40. A nossa mentalidade científica moderna concebe a realidade do mundo sem esse mistério, sem essa "profundidade valorativa" ${ }^{41}$ que a veneração faz ver. O mundo, visto sem a veneração, torna-se uma "operação aritmética trivial"42. Deus, o mundo e mesmo nosso eu só se manifestam em sua dimensão profunda com o olhar venerador, pois que o mero entendimento ou a mera percepção sobre o eu (o que normalmente tomamos como conhecimento, podemos dizer) pouco nos dizem sobre nós mesmos. Com a veneração, nós percebemos os limites do nosso entendimento diante do mundo e de nossa alma. Ao

\footnotetext{
${ }^{35}$ SCHELER, Max. Op. Cit., p. 25.

${ }^{36}$ Ibidem, p. 26.

${ }^{37}$ Ibidem, p. 27.

${ }^{38}$ Ibidem, p. 30.

${ }^{39}$ Idem.

${ }^{40}$ Ibidem, p. 36.

41 Ibidem, p. 37.

${ }^{42}$ Idem.
} 
mesmo tempo em que também nos abre a perceber que somos partícipes dessa dimensão divino-espiritual ${ }^{43}$.

O que se deve salientar dessa breve exposição sobre alguns pontos da análise das virtudes que Max Scheler empreende em seu ensaio é que elas, consoante ao seu pensamento, são aberturas a dimensões valorativas do mundo que se desvelam somente a partir de certos modos de visualização. Ou seja, as virtudes aqui podem ser entendidas também enquanto modos de se visualizar o mundo. A princípio podemos ver uma diferença entre a concepção de virtude de Aristóteles e a de Scheler, pois que este critica a noção de virtude enquanto hábito. No entanto, vemos que essa crítica de Scheler se refere mais à visão de virtude como uma habilidade que se torna um hábito adquirido por um esforço penoso, uma noção que retira o brilho que a virtude detinha. Tanto em Scheler quanto em Aristóteles a virtude se mostra como algo bom em si mesmo e que também traz frutos, um agir bem de modo natural, com o aperfeiçoamento de nossas capacidades (como o termo "excelência" nos faz ver) ou mesmo, em Scheler, um notar a dimensão valorativa do mundo.

\section{2. Éticas do senso moral}

David Hume, assim como os moralistas britânicos (Shaftesbury, Burke, etc), procura entender a moralidade em sua relação com a constituição humana e a vida social; em sua análise, as distinções morais não são próprias da razão, mas antes vinculadas com uma espécie de sentido ou sentimento moral. Para entender isto melhor, há que explicar algumas características da razão na concepção humiana. A razão consiste, segundo ele, na "descoberta da verdade ou da falsidade", estas que nada mais são que o acordo e o desacordo "seja quanto à relação real de ideias, seja quanto à existência e aos fatos reais" ${ }^{\text {"4 }}$, no comparar as ideias entre si ou em fazer alguma afirmação sobre os fatos. Além disso, a razão não tem, segundo Hume, qualquer influência direta na conduta humana, visto que precisa do intermédio das paixões. Por si só, ela não tem força. A razão influencia o comportamento só se despertar alguma paixão, na medida em que nos informa sobre a existência de algo que é objeto dessa

\footnotetext{
${ }^{43}$ Ibidem, p. 39.

${ }^{44}$ HUME, David. Tratado da Natureza Humana. São Paulo: Editora Unesp, 2009, p. 498.
} 
paixão, ou na descoberta de uma conexão entre causas e efeitos, dando meios para que uma paixão possa ser exercida. Ou seja, o que está mais diretamente ligado a uma ação é a paixão, sendo que a razão apenas a auxilia ou a influencia na medida em que tenta explicar algo sobre as coisas. Saber sobre estados de coisas e suas relações desperta determinadas paixões e somente estas conduzem realmente às ações.

De acordo com Hume, as características da razão citadas acima a distanciam da motivação moral. A moral tem sua influência em ações, mas não na forma de regras e preceitos morais. A razão não tem sozinha influência sobre as ações e as paixões; mas como a moral influi, de fato, nesses aspectos, a razão sozinha é aí impotente; as regras morais não são derivadas da razão, conclui Hume ${ }^{45}$. A respeito da característica da razão de descobrir a verdade e a falsidade, também não vemos conexão com a moral. Ser falso ou verdadeiro não é possível às nossas paixões e ações, visto que são realidades originais, completas em si mesmas, sem referência a outras paixões ou ações; ou seja, não cabem aí acordo ou desacordo, o que as impossibilita serem julgadas como verdadeiras ou falsas, contrárias ou conformes à razão. A razão não pode dizer se uma paixão ou uma ação são corretas ou erradas em um sentido ético.

Além desses argumentos, entre outros que Hume traz para a exclusão da razão do âmbito da moral, há um outro argumento, que consiste na pura e simples negação de um componente fundamental do pensamento ético: os fatos morais. O que isso vem a dizer? Que tudo aquilo que acontece e que, para muitos, pode ser considerado como atos virtuosos ou viciosos não tem em si mesmos nada que os faça ser assim; não há ato vicioso ou virtuoso em si mesmo, não há "fatos morais". Vemos isso, utilizando um exemplo de Hume, o caso de um homicídio. Em um romance policial, um detetive astuto pode descobrir quem foi o autor do crime e seus motivos para ter feito o ato; pode até mesmo inferir o estado emocional em que se encontrava o homicida, a julgar pelos indícios. Muito provavelmente ele vai julgar moralmente o crime, mesmo que não exponha seu juízo ao público, mantendo para si a sua visão. Pode considerá-lo, por exemplo, horrendo e, assim, como um vício. O detetive pode imaginar os pensamentos, motivos e sentimentos do homicida no ato do crime e, supondo-se que ele esteja correto em suas inferências, tudo isso constitui fatos: os pensamentos, os motivos, os

\footnotetext{
${ }^{45}$ Ibidem, p. 497.
} 
sentimentos envolvidos. Tudo isto nós podemos observar. No entanto, não podemos ver o vício - ele não está presente na cena do crime. Dizemos que o detetive o considerou horrendo, mas isso não está no próprio ato criminoso. O que temos é a impressão do detetive com relação ao ato, um sentimento de desaprovação. Em suma, segundo Hume, não é o ato em si que tem um caráter vicioso, mas nós próprios que temos em relação a ele um sentimento que nos faz desaprová-lo.

\footnotetext{
Aqui não há um fato, mas ele é objeto de sentimento [feeling], não de razão. Está em nós, não no objeto. Desse modo, quando declaramos que uma ação ou caráter são viciosos, tudo que queremos dizer é que, dada a constituição de nossa natureza, experimentamos uma sensação ou sentimento [a feeling or sentiment] de censura quando os contemplamos. Está em nós, não no objeto. $\mathrm{O}$ vício e a virtude, portanto, podem ser comparados a sons, cores, calor e frio, os quais, segundo a filosofia moderna, não são qualidades nos objetos, mas percepções na mente. ${ }^{46}$
}

A razão não tem ofício aí. É um sentimento o que funda a moralidade. Não há fatos morais que a razão pudesse observar e analisar. Deparamo-nos com certas ações, sentimentos, motivações, ou seja, com fatos presentes no caso; contudo, nada disso implica a presença de moralidade ou imoralidade. Elas emergem de um sentimento que temos quando nos deparamos com determinadas situações. Vemos, então, que todos os fatos que se observam no exemplo, de acordo com Hume, não têm ligação com a moral. São sensações, motivos, pensamentos o que observamos, mas o fato moral em si não há.

Isso nos conduz a um ponto bastante frisado no pensamento moral humiano que é sua distinção entre ser e dever ser. O filósofo nota que outros pensadores, analisando casos, hábitos, valores e comportamentos humanos, enquanto estão descrevendo aquilo que é, em algum momento, sem nenhuma justificativa, passam quase insensivelmente ao plano do dever. Ou seja, a partir do que ocorre, daquilo que é o caso, derivam que algo deve ser o caso, derivam um dever. Ora, afirma Hume, essa passagem não é legítima, visto que daquilo que é o caso não se deriva que isso deva ser.

\footnotetext{
${ }^{46}$ Ibidem, p. 508.
} 
Se, então, segundo Hume, a moralidade está relacionada ao sentimento em vez da razão, cabe explicar o que caracteriza estes "sentimentos morais". Algo que deve ser salientado, algo que é defendido pelos filósofos do senso moral - tanto o próprio Hume quanto os moralistas britânicos como Francis Hutcheson e Joseph Butler - é seu caráter empírico. Para Hutcheson, além dos habituais cinco sentidos (visão, olfato, etc., os denominados "sentidos externos"), e dos "sentidos internos", relacionados às "percepções agradáveis resultantes de objetos regulares, harmoniosos e uniformes, assim como da grandeza e da novidade", há também outras classes de sentidos: um "sentido público", que nos faz sentir prazer com a felicidade dos outros e constrangimento com seu infortúnio, um "senso moral", pelo qual se percebem as virtudes e os vícios, e um "senso da honra"47. Todos são classes de sentido, na medida em que este consiste em "toda determinação de nossa mente para receber ideias independentemente de nossa vontade e ter percepções de prazer e dor" ${ }^{\text {"48 }}$.

$\mathrm{Na}$ visão de Hume, estes sentimentos que emergem ao depararmo-nos com certas situações, de modo que as consideramos a partir daí como viciosas ou virtuosas, são afecções da mente, percepções que nos causam aversão ou apreço. Longe de um "mundo inteligível" (ao estilo de Kant, como veremos), em que a razão se infiltraria e forneceria as fontes da moralidade, esta, na visão empirista, se encontra no chão das percepções, sendo então os sentimentos provocados pelas impressões o que fornece a base para a moralidade.

\section{3. Éticas contratualistas: Thomas Hobbes}

A base da moralidade contratualista está na aceitação, em um pacto, de uma série de preceitos para o convívio de uma sociedade. Em Hobbes, o contrato é a via da paz, mesmo que em base na coação do Estado, contra o desacordo e a insegurança no estado de natureza. Segundo ele, o homem não é político por natureza (zoonpolitikon), como acredita Aristóteles, para o qual o ser humano se realiza apenas em comunidade. Somente uma consideração "superficial" da natureza humana, coloca o filósofo inglês,

\footnotetext{
${ }^{47}$ HUTCHESON, Francis. Ensaio sobre a natureza e conduta das paixões e afecções em: BUTLER, Joseph [et al] Filosofia moral britânica. Textos do século XVIII. Trad. Álvaro Cabral. $2^{\mathrm{a}}$ ed. Campinas: Editora Unicamp, 2013, p. 181-182.

${ }^{48}$ Ibidem, p. 181.
} 
levaria a se concluir que o homem seria animal político. Porém, essa premissa, de acordo com Hobbes, está na base de teorias sobre a origem da sociedade civil, segundo as quais é "como se, para se preservar a paz e o governo da humanidade, nada mais fosse necessário do que os homens concordarem em firmar certas convenções e condições em comum, que eles próprios chamariam, então, leis" ${ }^{\text {"49; }}$ sendo que ainda seria necessário, segundo Hobbes, algo que os mantivesse no acordo. Mas, se o ser humano não é político por necessidade da natureza, é devido à natureza humana que a política se faz necessária.

O ser humano não é naturalmente ligado a uma comunidade, mas apenas por acidente. $\mathrm{O}$ ser humano não é um animal social; liga-se à sociedade por interesses próprios e egoístas. Não lhe apraz a companhia dos outros, muito pelo contrário, ela lhe causa imenso desprazer. Hobbes procura mostrar isso no capítulo Da condição humana fora da sociedade civil no livro em Do cidadão. O ser humano se vincula à comunidade não por amor aos outros, mas por amor a si mesmo. De acordo com o que afirma, qualquer reunião se realiza ou por medo recíproco ou por "vã glória". Uma associação que foi feita voluntariamente acontece por busca do objeto da vontade por parte de seus integrantes, aquilo que cada um se propõe como bem. E aquilo que se tem como bom é, segundo Hobbes, agradável para os sentidos ou para a mente, sendo que ao primeiro o que apraz é sensual ou conduz à sensualidade, e ao segundo, a glória - "a boa opinião de si mesmo" -, ou o que leva à glória.

Desse modo, uma associação pode se erigir na busca da glória; todavia, tal união não poderia ser grandiosa ou duradoura, porquanto, como na honra, se todos têm glória, ninguém de fato a tem. Por isso Hobbes afirma que essa associação é por vã glória, pois a glória consiste, como conceitua no capítulo IX da primeira parte de Os elementos da lei natural e política, em uma "paixão que procede da imaginação ou concepção do nosso próprio poder sobre o poder daquele que está em disputa conosco". Quando essa paixão decorre de uma consciência segura de nossos atos, que sabe se estes são realmente dignos de nossas ostentações, tem-se uma glória verdadeira. A vã glória seria aquela que procede "não de alguma consciência de nossas próprias ações, mas da fama e da confiança de outrem, pelo que é possível pensar de si mesmo"; é, portanto, uma

\footnotetext{
${ }^{49}$ HOBBES, Thomas. Do Cidadão. 3. São Paulo: Martins Fontes, 2002a, p.26.
} 
falsa glória, e é vã, pois "não gera nem apetite nem ímpeto para qualquer tentativa futura" ${ }^{, 50}$. As sociedades que são duradouras advêm, por conseguinte, do medo recíproco. De acordo com Hobbes, se pudesse ser retirado todo o medo que nos habita, a natureza humana tenderia muito mais à dominação do que à associação, visto que, apesar de os benefícios da vida serem ampliados na ação recíproca no âmbito de uma sociedade, são mais fáceis de se obterem pelo domínio ${ }^{51}$. Entrementes, o medo existe, e ele decorre da condição humana em seu estado de natureza.

Os humanos, na visão de Hobbes, são iguais por natureza; as desigualdades que possam existir (escravos, cidadãos, governantes, etc.) são oriundas da vida em sociedade. Aquela igualdade original advém de sua fragilidade: todo ser humano é constituído de um corpo frágil, de modo que todos são facilmente passíveis de sofrer dano ou até mesmo de serem mortos por outros. Para Hobbes, então, "são iguais aqueles que podem fazer coisas iguais um contra o outro; e aqueles que podem fazer as coisas maiores (a saber: matar) podem fazer coisas iguais" ${ }^{\prime \prime 2}$. Porém, apesar dessa igualdade, eles se diferem no tocante à diversidade de suas paixões, pois enquanto uns se movem por sua vã glória e "desejam (hope) precedência e superioridade sobre os seus pares",53, os outros, mais "moderados", procuram apenas assegurar sua igualdade dada por natureza, e têm de ser ofensivos com os que são movidos pela "vã glória". Assim, surgem duas formas pelas quais os humanos sentem vontade de se ferirem uns aos outros: dos que almejam superioridade e se impõem aos outros, e daqueles que procuram se defender.

Como já se disse, a glória é prazer da mente, ou aquilo que a ela leve; assim os humanos gostam de se vangloriar dos outros e odeiam quando encontram qualidades nestes, sendo desse modo que se provocam mutuamente, por meio de palavras e de gestos, chegando a ponto de quererem se agredir. A discórdia entre as pessoas surge disso, da "comparação entre as vontades", e principalmente por nós, seres desejantes, sermos levados por nossos apetites aos mesmos fins, os quais, por muitas vezes, não podem ser aproveitados por todos.

50

51

52

Ibidem, p. 29.
Os Elementos da Lei Natural e Política. São Paulo: Ícone, 2002b, p. 57-58.

Do Cidadão. 3. São Paulo: Martins Fontes, 2002a, p. 28.

Os Elementos da Lei Natural e Política. Op. Cit., p. 94. 
Algo importante no pensamento moral de Hobbes é a inexistência do bom e do mal, do correto e do errado, no estado de natureza. Dessarte, o que é bom é o objeto de desejo do indivíduo, assim como o mal é o objeto de aversão. Os humanos se movem naturalmente em direção àquilo que lhes é mostrado como bom e repelem-se do que julgam ruim. Entretanto, embora não exista, para Hobbes, algo que seja intrinsecamente bom ou mau, há aquilo que todos consideram como o maior dos males e do qual todos fogem, qual seja, a morte - principalmente a morte dolorosa, que podemos entender como o sumo mal.

O desejo de autopreservação é natural. Com isso, também é natural que o ser humano faça de tudo que possa para a sua preservação. Aliás, não contraria a razão que ele tome as providências que lhe forem necessárias e possíveis para evitar a morte e o sofrimento. Disso, então, Hobbes tira o primeiro direito natural: "a primeira fundação do direito natural consiste em que todo homem, na medida de suas forças, se empenhe em proteger sua vida e membros" ${ }^{, 54}$. Direito natural em Hobbes conceitua-se como a liberdade que têm todos os humanos de se utilizarem de suas faculdades de acordo com o bom uso da razão. Não é, pois, uma concepção moral. Considera-se, por extensão, como direito natural tudo o que se pode fazer para adquirir algum bem ou evitar algum mal.

Todos os humanos têm por direito natural a possibilidade de adquirirem todas as coisas. Isso poderia, à primeira vista, parecer bom, mas é, na verdade, inútil. Tendo em vista que para atingir determinado fim é necessário o uso de certos meios, é direito a utilização de quaisquer meios para se chegar ao objetivo. Isso significa que não somente eu posso fazer de tudo que esteja em meu poder para obter algo, como também está no direito do outro a obtenção disso; ele pode me retirar aquilo que tenho, eu posso resistir, e assim por diante; tudo isso, utilizando-se de todos os meios que estiverem à mão. Isso implica uma guerra de todos contra todos, já que os humanos são egoístas e hostis uns aos outros. Os seres humanos, pois, em sua liberdade plena, afundam-se em um estado caótico de guerras e hostilidades. "O estado dos homens em sua liberdade natural é o estado de guerra. Pois a guerra nada mais é do que o tempo no qual há vontade de contestar por meio da força, seja com palavras ou ações suficientemente declaradas"

54 55 Do Cidadão. Op. Cit., p. 31. . Os Elementos da Lei Natural e Política. Op. Cit., p. 96. 
Como todo indivíduo tem por objetivo a autopreservação, e a situação no estado de natureza é a de guerra de todos contra todos, não lhe é viável permanecer nesse estado. É pela reta razão que o humano deve procurar a paz quando esta lhe for possível e fazer de tudo que puder para consegui-la; ou seja, é lei de natureza a busca pela paz.

Os humanos têm de compactuar entre si em busca da paz. Não basta apenas consenso, ou seja, não é suficiente somente um direcionamento da vontade de todos a um fim comum, pois, devido à hostilidade da natureza humana, eles em não muito tempo terão discordâncias, e a paz não se manterá - como já se disse, as teorias políticas que acreditam em que basta as pessoas chegarem a um acordo e convencionarem leis que moldem as ações de todos, pressupõem que o humano seja naturalmente um animal político, o que Hobbes nega. Não basta, então, apenas consenso. Com isso, Hobbes vai àquilo que não é racional, mas é algo que move o ser humano: o medo ${ }^{56}$. Os humanos devem submeter suas vontades ao comando de uma pessoa ou de um conselho; o poder é passado a um único ponto.

Se com a liberdade (em sentido de desimpedimento) do estado de natureza as pessoas viviam em guerra, devem então transferi-la para um poder central, de modo que não lhes reste nenhuma liberdade, para evitar que se volte ao estado de guerra. $\mathrm{O}$ soberano deterá, assim, tanto poder que, por medo, seus súditos serão motivados a manter a paz. Se é por paixão que o ser humano vive em guerra no estado de natureza, é por paixão que se manterá a paz na sociedade civil. Hobbes escreve,

ainda quando um homem convenciona submeter sua vontade ao comando de outrem, ele obriga a si mesmo a renunciar de sua força e recursos em favor daquele a quem ele convencionou obedecer. E por isso aquele que comanda pode, pelo uso de todos os meios e força, habilitar-se pelo terror a moldar a vontade de todos aqueles pela unidade e concórdia, entre eles mesmos ${ }^{57}$.

\footnotetext{
${ }^{56}$ Vê-se que o ser humano tende a seguir os imperativos de seus impulsos, em vez dos ditames da razão. Assim, ele é mais movido por seu lado irracional (vontade, medo) que pela razão. Isso se diferencia, no entanto, de filósofos como Schopenhauer e Matias Aires, para os quais a vontade de vida ou a vaidade, respectivamente, não somente guiam as atitudes humanas, como também condicionam a razão. Razão e vontade são independentes em Hobbes, tanto que se podem perceber, pelo uso da razão, as leis naturais, como foi visto acima. Em suma, o ser humano pode se guiar por uma razão livre, mas tende a seguir impulsos como medo e vontade.

${ }^{57}$ Ibidem, p. 131.
} 
Se na visão aristotélica a vida em comunidade é o que possibilita ao indivíduo a obtenção do maior dos bens, a felicidade, que é o próprio fim da natureza humana, em Hobbes, a comunidade política aparece como o mal menor para evitar o caos do estado de natureza, o estado de guerra de todos contra todos, em que o homem é o lobo do homem. A natureza humana tem de ser freada pela comunidade política no que se refere ao movimento desenfreado dos humanos guiado pela vontade. Assim, aquilo que também lhe é natural, o instinto de autopreservação, leva-o a sair do estado de natureza, a partir de um acordo racional feito pelo contrato; contrato esse que será, numa teoria ética contratualista, o fundamento da moralidade.

O soberano, a quem foi dado o poder, deteria total domínio sobre seus súditos, estes abdicando de suas liberdades por meio do contrato. A ordem seria mantida através do medo; ora, como já foi dito, as pessoas somente pelo uso da razão não se ateriam a seus deveres, por isso o que deve motivar os indivíduos a agirem de acordo com as leis é o medo de um mal maior por vir caso não cumpram o contrato. Para a permanência da paz, é necessário que os humanos se desmotivem a seguirem suas vontades; é preciso um artifício pelo qual os indivíduos devam frear seus impulsos. O soberano deve lançar mão de castigos que demonstrem que é melhor abster-se de suas vontades a serem castigados $^{58}$.

Por conseguinte, o Estado em Hobbes é o artifício necessário para transformar o homem lobo - o qual é movido por seus impulsos, direcionando suas ações aos mandamentos de sua vontade, utilizando-se de todos os meios que the estiverem à mão para atingir os seus fins, o que gera o estado de guerra de todos contra todos - em homem civilizado, que se priva de sua liberdade em troca da paz, que é mantida pelo temor do poder absoluto do soberano. Se não é da natureza humana que se deriva a comunidade política, ou seja, se ela não tem uma constituição inevitável, deve surgir do contrato, sendo uma solução para os problemas oriundos do estado natural dos humanos.

A partir do que foi dito, podemos sintetizar melhor o que caracteriza uma ética contratualista. Vimos que na teoria hobbesiana, pela busca da autopreservação, passa-se

58 Do Cidadão. Op. Cit., p. 103-104. 
do caótico estado de natureza, para o estado civil, por meio de um contrato. Para os contratualistas, o contrato não é algo factual, realizado em um passado remoto, nem possivelmente tenha existido um estado de natureza. A questão reside no uso de um artifício intelectual para a justificação das regras do estado civil e do Estado, e assim também da moralidade, que tem por fim a manutenção da sociedade; em suma, a moralidade está em função da sociedade. Uma ação torna-se correta se está de acordo com os preceitos e normas (aqui se vê um elemento deontológico) de um estado civil, que foram implicitamente aceitos no contrato hipotético. $\mathrm{O}$ acordo e as regras constituem aquilo que indivíduos sob certas condições aceitariam, e que no caso de Hobbes consistiriam em seguir a reta razão em busca da autopreservação, mas que também pode ser, por exemplo, deter razoabilidade, bom senso, razão, liberdade, etc. Portanto, o fundamento da moralidade não consiste em fatos morais, no que seria certo ou errado em si mesmo, nem em alguma ordem cosmológica ou divina, mas se apoia nas mãos humanas, que se juntam para compactuar e fundar os preceitos e regras de uma sociedade em vista do convívio social.

\section{4. Éticas utilitaristas: Stuart Mill}

O utilitarismo é uma das éticas denominadas de teleológicas, isto é, éticas que focam as ações humanas como com vista a um fim; no caso do utilitarismo, esse fim é a utilidade. Na concepção utilitarista, a utilidade é o bem-estar ou felicidade da maioria. Dessarte, esta é a tese central do utilitarismo, segundo John Stuart Mill, seu principal representante, que a regra da ação, para ser ética, tem de ter em vista a felicidade do maior número, e nisso consiste o Princípio da maior felicidade. "A doutrina que aceita como fundamento da moral a utilidade, ou o princípio da maior felicidade, defende que as ações são corretas na medida em que tendem a promover a felicidade, e incorretas na medida em que tendem a gerar o contrário da felicidade"59. A ação é correta ou incorreta em sentido ético utilitarista pela sua tendência de levar à felicidade geral. A felicidade, como conceitua Mill, é “o prazer ou ausência de dor”, ao passo que por infelicidade entende-se "a dor, e a privação de prazer"60.

\footnotetext{
${ }^{59}$ MILL, Stuart. Utilitarismo. Trad. F. J. Azevedo Gonçalves.Lisboa: Gradiva, 2005, p. 50-51.

${ }^{60}$ Idem.
} 
Guiar-se pelo prazer já foi estipulado por outros pensadores muito anteriores, como o próprio filósofo o reconhece. A filosofia clássica que prega tal doutrina é o Epicurismo. Segundo Epicuro, o prazer é "a realização suprema da felicidade" e ele é entendido enquanto "a ausência de sofrimento no corpo e a ausência de perturbação na alma" ${ }^{\text {"61 }}$. No entanto, não é todo prazer que deve ser perseguido, segundo os epicuristas, sendo que alguns prazeres são, na verdade, um mal, e alguns sofrimentos, bens; quando, por exemplo, sofremos uma dor em consequencia de uma cirurgia para nos livrarmos de uma doença; isto é, trata-se de um sofrimento ou um mal, mas em vista de um bem, que é a saúde. É preciso então, para Epicuro, saber fazer um cálculo daquilo que é útil e do que é prejudicial em vista do que constitui o verdadeiro bem. O prazer, de fato, não está na voluptuosidade ou em banquetes, consiste na ausência de dor no corpo e de perturbação na alma ${ }^{62}$.

$\mathrm{Na}$ abordagem utilitarista de Stuart Mill, a felicidade é entendida de uma maneira próxima a dos epicuristas, dado que também se liga ao prazer e à ausência de dor. Porém, distancia-se deles ao pressupor que existam várias formas de prazeres em vez de um único e verdadeiro prazer supremo, embora também o utilitarismo faça distinção entre diferentes tipos de prazeres. Em Stuart Mill, uma inovação que trouxe em seu pensamento utilitarista, e que não se encontra nem sequer em seu mentor Jeremy Bentham, é o valor não apenas quantitativo mas qualitativo nos prazeres considerados. "É perfeitamente compatível com o princípio de utilidade reconhecer o fato de alguns tipos de prazer serem mais desejáveis e valiosos do que outros. Seria absurdo que a avaliação dos prazeres dependesse apenas da quantidade, dado que ao avaliar todas as outras coisas consideramos a qualidade a par da quantidade"63. Dessarte, para Stuart Mill alguns tipos de prazer são superiores e outros inferiores. Existem prazeres que nós compartilhamos com outros animais, como os apetites (saborear uma refeição e a luxúria, entre outros); ao passo que há prazeres associados às nossas faculdades superiores, tais como o uso do intelecto, as emoções e o sentimento moral. Nem todos os indivíduos se mostram interessados nos prazeres superiores; porém, Stuart Mill assegura que aqueles que conseguem desfrutar dos dois tipos de prazeres, certamente terão preferência pelos prazeres superiores, o que indica que são os mais desejáveis.

\footnotetext{
${ }^{61}$ EPICURO, Epistola a Menoiceus apud LAÊRTIOS, Diógenes. Op. Cit., p. 313.

${ }^{62}$ Idem.

${ }^{63}$ MILL, Stuart. Utilitarismo. Op. Cit., p. 52.
} 
De certo, acontece de os indivíduos que se deleitam com o modo de vida associado aos prazeres superiores serem mais infelizes ou terem mais facilidade em se verem envolvidos em forte sofrimento. Uma pessoa com aguda sensibilidade moral pode facilmente afligir-se com as situações de dor e injustiça que perpassam a vida cotidiana. Todavia, afirma Mill, nenhum indivíduo inteligente escolheria ser idiota para se sentir satisfeito, preferindo assim a insatisfação que ele possa ter com a vida mais elevada, pautada nos prazeres superiores, do que uma felicidade inferior. No mais, sua famosa fala resume a questão: "É melhor ser um ser humano insatisfeito do que um porco satisfeito; um Sócrates insatisfeito do que um tolo satisfeito. E se o idiota, ou o porco, têm opinião diferente, é porque apenas conhecem o seu lado da questão. A outra parte da comparação conhece ambos os lados" ${ }^{\prime 64}$. Portanto, na teoria de Stuart Mill há a afirmação de uma diferença entre prazeres superiores e inferiores, que condizem com diferentes formas de vida, as quais, embora não fortemente determinadas (não há uma indicação firme e objetiva de quais são os melhores modos de viver), são as que estão associadas a esses diferentes tipos de prazer.

O ponto importante para o filósofo na afirmação e acentuação dos prazeres superiores está no fato de que eles beneficiariam a maioria. Uma pessoa que cultiva uma vida virtuosa, ou seja, satisfaz-se com prazeres superiores, traz com isso não só benefício a si próprio como também aos outros. Certamente, uma pessoa que procura ser justa, preza pela gentileza, etc., beneficia os outros por esse seu caráter. E o fim da ação ética, na abordagem utilitarista, é o bem-estar geral, o que significa que uma forma de vida que condiz mais com esse preceito utilitarista é mais valorizada.

No entanto, a virtude não tem valor em si mesma, como no caso das éticas de virtudes, mas em vista do útil, a saber, da felicidade geral. Como no exemplo de Stuart Mill, de um indivíduo que consegue alcançar um nível bastante alto de ascetismo: a capacidade de abdicar de seus prazeres - prazeres esses que são o objeto ao qual naturalmente o ser humano tende, na concepção utilitarista de Mill - pode ser algo admirável. Más é demais exigir um grande ato de autossacrifício em prol da felicidade geral, algo comparável ao heroísmo ou à santidade, o que nas questões éticas conceituamos como ações suprarrogatórias, ou seja, ações que vão além do que se pode

\footnotetext{
${ }^{64}$ Ibidem, p. 54.
} 
exigir. Entretanto, esse não é o caso do ascetismo em vista apenas à própria excelência, que nos mostra o que somos capazes de fazer, mas que não aponta para o que devemos de fato fazer, algo que não teria utilidade no sentido utilitarista:

Honra seja feita àqueles que conseguem renunciar por si mesmos os deleites pessoais da vida, quando mediante tal renúncia contribuem de forma válida para o aumento da quantidade de felicidade no mundo; mas aquele que o faz, ou professa fazê-lo, com qualquer outro objetivo, não é mais merecedor de admiração do que o asceta empoleirado no seu pilar. Pode ser uma prova inspiradora do que os homens são capazes de fazer, mas não é seguramente um exemplo do que devem fazer ${ }^{65}$.

Além de não valorizar as virtudes em si mesmas, também não é importante para uma ação ética, no utilitarismo, a sua motivação. Como vimos, Mill afirma os prazeres superiores, pois que eles propiciam o benefício da maioria. Uma pessoa que se apraz com a vida virtuosa pode agir com boa intenção, de modo que propicie bem-estar aos outros. Todavia, a ação mesma para ser ética não precisa de uma boa motivação, indo de encontro ao pensamento moral de teóricos como Kant, para o qual a boa vontade, querer o dever, é fundamental. "O objetivo da ética é dizer-nos quais são os nossos deveres, ou por que meios podemos conhecê-los; mas nenhum sistema de ética exige que o único motivo de tudo o que façamos seja um sentimento de dever" ${ }^{\prime 66}$. Com efeito, muitos outros motivos, não necessariamente morais, levam-nos a agir, e as ações podem ou não serem daquelas que são em vista da felicidade geral. É a ação em si que é correta ou errada.

Por exemplo, ajudar os pobres pode ser considerado uma ação correta mesmo que a motivação seja egoísta, como livrar-se de um constrangimento ou querer passar-se por um benfeitor para um público qualquer. "Quem salva um semelhante de se afogar faz o que está moralmente correto, quer o seu motivo seja o dever, ou a esperança de ser pago pelo seu incômodo; quem trai a confiança de um amigo, é culpado de um crime, ainda que seu objetivo seja servir outro amigo para com o qual tem deveres ainda maiores" ${ }^{\text {"67 }}$. Não que Stuart Mill não dê valor à motivação (ela diz muito sobre o agente), mas que a

\footnotetext{
${ }^{65}$ Ibidem, p. 62.

${ }^{66}$ Ibidem, p. 65. Vemos claramente que há a exceção de Kant.

${ }^{67}$ Idem.
} 
motivação não dá valor moral ao ato. Assim, não serão as ações pela esteira da virtude ou da boa intenção aquilo que determinará seu caráter ético, e sim a ação em si mesma que é correta, na medida em que é direcionada ao bem-estar das pessoas.

O crivo, portanto, é a felicidade geral, e isso quer dizer que o acento está posto nas consequências da ação. Dessarte, a ética utilitarista admite exceções com respeito a alguns preceitos morais. Além do princípio da utilidade, da felicidade geral, Stuart Mill afirma a existência de princípios intermediários. No decorrer da existência humana, as pessoas foram tomando conhecimento, pela experiência adquirida, de alguns princípios generalizáveis da ação, na medida em que eles promovem o bem-estar. Podemos tomar como exemplo o caso da mentira. Dizer a verdade é uma das coisas mais úteis, no sentido utilitarista, sendo que o seu contrário é bastante prejudicial para o convívio social, ou seja, o bem geral, de modo que dizer uma mentira em benefício próprio é condenável. Nas palavras que deslizam nos textos de Stuart Mill:

\footnotetext{
... na medida em que qualquer desvio da verdade, ainda que involuntário, leva, na mesma proporção, ao enfraquecimento da fiabilidade das afirmações humanas, fiabilidade essa que é não apenas o suporte principal de todo o bem-estar social presente, mas cuja insuficiência faz mais do que qualquer outra coisa para retardar a civilização, a virtude e tudo aquilo de que depende a felicidade humana em larga escala; sentimos que a violação de uma regra de tão transcendente expediência para obter um ganho para si ou para qualquer outro indivíduo, faz o possível para privar a humanidade do bem, e infligir o mal, envolvido na maior ou menor confiança que os seres humanos podem colocar na palavra uns dos outros, desempenha o papel de um dos piores inimigos da humanidade ${ }^{68}$.
}

Assim, zelar pela verdade seria um preceito utilitarista. Se a orientação principal do utilitarismo, como sabemos, é o princípio da felicidade da maioria, os princípios secundários devem se orientar por esse princípio mais fundamental; isso ocorre, segundo Mill, com o preceito de se orientar pela veracidade. Entretanto, na medida em que as consequências são o mais importante, há casos excepcionais em que se deve violar uma regra. Por vezes, devemos mentir, apesar do preceito que o condena. Em alguns momentos, por segurança, devemos omitir informações para salvar alguém de

\footnotetext{
${ }^{68}$ Ibidem, p. 71.
} 
algum mal. Sabe-se que são as consequências que, no fim das contas, importam e, no caso do utilitarismo, as consequências ligadas à promoção do bem-estar geral. Os preceitos secundários são aqueles que, normalmente, promovem o princípio da maior felicidade. E nisso reside uma resposta de Mill à objeção de que seria complicado fazer cálculos para saber se uma ação promove ou não o bem da maioria. Mill afirma que a história humana nos trouxe experiência para julgar isso; "houve muito tempo, isto é, toda a existência prévia da espécie humana. Durante todo esse tempo, a humanidade tem estado a aprender por experiência as tendências das ações; e é dessa experiência que dependem toda a prudência e toda a moralidade da vida" ${ }^{\text {}}$. É um aprendizado ainda em curso, de modo que os preceitos derivados dessa experiência são aperfeiçoáveis e por vezes admitem exceções, mas não quer dizer que não se disponha de orientações só porque tais preceitos não sejam absolutos.

A afirmação de Mill sobre a existência de princípios secundários pode aproximálo ao que se denomina atualmente um utilitarismo de regras. Enquanto o utilitarismo de casos, como o nome já indica, afirma que cada caso, cada situação requer o cálculo a fim de maximizar o bem-estar da maioria, o utilitarismo de regras valoriza as ações que presumivelmente promovem a felicidade geral. E o que são os princípios secundários senão preceitos que, ao longo da existência humana, pudemos perceber que tendem a maximizar o bem-estar? Havemos, contudo, de esclarecer certos pontos. Afirmou-se o acento nas consequências e que, com isso em mente, devemos por vezes ir de encontro a alguns preceitos, como no caso da mentira para evitar um mal. No entanto, no utilitarismo de regras deve-se agir de acordo com as ações que presumivelmente levam a maior felicidade; isso de modo que, se se age diferentemente e por acaso as consequências forem positivas, a ação ainda assim será considerada errada, pois que normalmente não levaria a maximização da felicidade. Da mesma forma, agir de acordo com a ação que presumivelmente traria maior bem-estar é o correto, mesmo que em certa situação ocorra inesperadamente uma consequência negativa.

Ora, se os preceitos são ações que presumivelmente levam à maximização da felicidade e deve-se agir de acordo com esses tipos de ações, como então poderia ser aceita a mentira em certos casos, ou seja, a violação de um preceito? Os preceitos são

\footnotetext{
${ }^{69}$ Ibidem, p. 72.
} 
aquilo que costumam promover o princípio utilitarista, mas eles não são sempre os que presumivelmente o promovem. Em alguns casos, a mentira presumivelmente terá melhores consequências.

Eis, portanto, o utilitarismo como a doutrina que visa à felicidade da maioria, felicidade que consiste na realização de prazeres e evitar o sofrimento, o que já os humanos tendem a desejar. Se for esse o fim da ética utilitarista, uma ação humana é correta na medida em que tende a realizar o bem-estar da maioria. $\mathrm{O}$ bem-estar, ou seja, os prazeres não são avaliados somente quantitativamente mas sobretudo qualitativamente, na medida em que concernem a características superiores e destacantes do humano, como o intelecto e o sentimento moral.

\section{5. Éticas deontológicas. Às voltas de Kant: o dever e a vontade}

Kant é o filósofo clássico mais associado às ética deontológica ou ética dos deveres, já que a noção de dever é central em sua ética. Relaciona-se com o que deve ou não se deve fazer, não para algum fim, mas porque é o correto, o que não necessariamente leva a alguma realização de algum objetivo. Mais marcadamente distante das éticas do bem viver, a ética kantiana não busca trazer uma orientação para o bem agir em vista da felicidade (que, para os antigos, identificava-se com uma vida moral); ao contrário, a felicidade, além de não ser fim da ética, numa ética deontológica, pode mesmo ter sua renúncia à felicidade exigida em prol do dever.

Poder-se-ia arguir que há pessoas que se comprazem com a ação moral. São pessoas honradas, atenciosas, dispostas a agir em benefício dos outros, etc., em suma, agem conforme o dever e se sentem bem por isso. Assim, elas teriam uma forma de vida ética que, ao mesmo tempo, torna-as felizes, sendo então possível uma ética deontológica do bem viver ${ }^{70}$. No entanto, uma primeira distinção que Kant realiza em

\footnotetext{
${ }^{70}$ Já se viu que a noção de felicidade varia nas distintas éticas eudemônicas, embora tendam a convergir em associá-la com a autorrealização humana. Procuramos aqui uma noção mais corrente, a qual, embora possa não coincidir com as noções antigas de felicidade, vai a encontro de uma possível conciliação entre bem-estar e ética. O próprio Kant, indo em direção contrária a uma noção estreita de felicidade, afirma que há várias noções de felicidade; contudo vê-se que algumas delas podem já não estar relacionadas a alguma autorrealização.
} 
seu sistema moral já dificulta essa ligação entre ética e felicidade, a saber, a distinção entre agir conforme ao dever e agir pelo dever.

A ação conforme ao dever, como já se depreende dos termos, é uma ação que coincide com aquela que é exigida pela ética, ou seja, age-se de acordo com o que deve ser feito. Isso, porém, não lhe dá ain da, segundo Kant, um caráter genuinamente ético, porquanto pode não ser feita por dever. Isto é evidente, por exemplo, quando alguém se recusa a mentir mas apenas por medo de ser descoberto e retaliado; nesse caso, a motivação que levou o indivíduo a agir corretamente é o mero medo, ou seja, uma motivação egoísta. Esse é um caso que mais facilmente vemos de não agir pelo dever; porém a questão se complica, afirma Kant, quando o agente tem uma inclinação natural a agir corretamente. $\mathrm{O}$ caso de um filantropo que estivesse disposto a ajudar os outros, seria mais difícil de analisar. Ajudar aos outros que precisam, quando tal coisa é possível, é um dever; todavia, não se sabe se o filantropo está agindo por uma inclinação natural - piedade, simpatia - ou estritamente pelo dever. Ao contrário, segundo Kant, se ocorresse que esse mesmo indivíduo perdesse toda a sua inclinação, que a miséria dos outros não o comovesse, ou mesmo que a ajuda lhe tornasse penante, porém mesmo assim ele os ajudasse, simplesmente pelo dever, aí sim teríamos uma ação de genuíno valor moral ${ }^{71}$. Se o filantropo buscasse agir de acordo com o dever, mesmo que toda a sua natureza o impelisse em direção contrária a essa ação moral, "não poderia ele encontrar dentro de si um manancial que the pudesse dar um valor muito mais elevado do que dum temperamento bondoso? Sem dúvida!"72.

Apesar disso, Kant não recusa toda importância para a felicidade na teoria moral. E em certo momento do texto, chega a afirmar que a felicidade é, "ao menos indiretamente", um dever. Ela não é o fim da ética e muitas vezes pode não estar de acordo com o dever, sendo exigida a sua renúncia; contudo reconhece seu valor ético na medida em que possibilita que o indivíduo aja de acordo com o dever; uma pessoa totalmente infeliz não parece estar nas melhores condições de observar seus deveres; ou

\footnotetext{
${ }^{71}$ KANT, Immanuel. Fundamentação da Metafísica dos Costumes. Trad. Paulo Quintela. Lisboa: Edições 70, 2008, p. 28-29 [BA 11].

${ }^{72}$ Idem.
} 
seja, deve-se assegurar a felicidade na medida em que ela ajuda a evitar que o agente transgrida os deveres ${ }^{73}$.

A distinção entre conformidade ao dever e agir pelo dever é um elemento que leva Kant a ter certo ceticismo em encontrar exemplos de ação moral na empiria ${ }^{74}$. Algo bastante próximo encontramos também na seguinte passagem de um texto do moralista Bernard Mandeville.

\begin{abstract}
Não há mérito algum em salvar um bebê inocente prestes a cair no fogo: a ação não é boa nem má e, independentemente de qualquer benefício que a criança tenha recebido, só fizemos um favor a nós mesmos, pois tê-la visto cair nas chamas e não procurar evitá-lo teria causado um sofrimento que a autopreservação nos compele a impedir $[\ldots] .^{75}$
\end{abstract}

Claro, porém, que a distinção kantiana entre ação conforme e pelo dever não está no texto de Mandeville, este que buscava dar uma explicação natural das virtudes morais. Todavia, há nessa passagem uma explicação para uma ação negando-lhe genuina motivação moral, o que condiz com a distinção kantiana: embora a ação seja conforme ao dever, não se realiza pelo dever.

Mandeville está entre os denominados moralistas britânicos, filósofos que influenciaram Kant. Eles, de tendência empirista, procuram entender a estrutura do agir moral e sua conexão com a natureza humana, além de terem como método, para a sua fundamentação da moral, partir da visão que as pessoas comuns têm com respeito à moralidade. São dois elementos que podemos ver em Kant: a conexão entre moralidade e natureza humana e o método que leva em conta a visão moral comum. Contudo, Kant se distancia dos britânicos por assumir uma postura marcadamente não empirista. Precisamente, ele procura, na Fundamentação da Metafísica dos Costumes, investigar a possibilidade de uma filosofia moral sem elementos tomados da experiência ${ }^{76}$. E essa eliminação da empiria Kant já a descobre na noção comum de dever e de lei moral,

\footnotetext{
${ }^{73}$ Ibidem, p. 29 [BA 11-12].

74 Ibidem [BA 26-27]

${ }^{75}$ MANDEVILLE, Bernard. Uma investigação sobre a origem da virtude moral em: BUTLER, Joseph [et al] Filosofia moral britânica. Textos do século XVIII. Trad. Álvaro Cabral. $2^{\mathrm{a}}$ ed. Campinas: Editora Unicamp, 2013, p. 96.

${ }^{76}$ KANT, Immanuel. Op. Cit., p. 13-14 [BA IV,V].
} 
aplicando seu método de partir das distinções morais comuns. A visão comum julga que uma lei moral tem de ter necessidade absoluta. Disto Kant infere que ela não deve valer apenas para a especificidade da natureza humana ou das contingências do mundo, mas para todo ser racional; as leis morais devem constituir leis a priori discerníveis pela razão pura ${ }^{77}$.

Então, quando afirmamos que Kant está próximo dos moralistas ingleses no reconhecimento de uma conexão entre moralidade e natureza humana, há de se esclarecer o seguinte ponto: no caso de Kant, a moralidade não concerne apenas às especificidades empíricas do humano, visto que as leis morais valem para o ser humano enquanto ser racional. A moralidade que Kant tem em vista há de ter validade para todo ser racional que possa existir. No entanto, na Fundamentação da Metafísica dos Costumes, Kant não estabelece leis morais específicas, embora mencione alguns exemplos de deveres. Ora, a característica de uma ética deontológica é justamente a centralidade nos deveres nas considerações morais. As leis morais seriam, então, indicação do que se deve ou não ser feito. Vemos já este elemento no Decálogo cristão, nos mandamentos, elemento deontológico da ética cristã. "Não matarás" e "Amar a Deus sobre todas as coisas" são exemplos desses mandamentos e, como vemos, têm um conteúdo especificado.

O que Kant estabelece, em vez de leis específicas, é um princípio supremo da moralidade. (Isto configura o que se denomina o "formalismo" kantiano) $\mathrm{Na}$ primeira seção do mencionado livro, o filósofo parte da concepção moral comum e chega ao primeiro princípio, que está pressuposto na visão moral comum, o de que "nunca devo proceder de outra maneira senão de tal sorte que eu possa querer também que a minha máxima se torne uma lei universal ${ }^{\text {"78 }}$. Tal princípio será ainda melhor formulado na segunda seção, tendo duas fórmulas: a fórmula da Lei Universal e a fórmula da Lei de Natureza, como veremos. Por enquanto cabe afirmarmos que Kant retira este princípio da moral comum para, depois, elevá-lo ao status filosófico. Ele mostra esse princípio no exemplo da promessa. Pergunta-se se é permitido que se faça uma promessa quando se está em apuros. Em certos casos, seria prudente de fato; haveria de refletir se essa mentira valeria a pena, se não levaria a más consequências, etc.. Contudo, mesmo se for

\footnotetext{
${ }^{77}$ Ibidem, p. 15 [BA VIII].

${ }^{78}$ Ibidem, p. 33 [BA 17].
} 
prudente agir dessa maneira, ou seja, realizar uma falsa promessa, seria isso moral? Haveria de ver se a máxima "Usar de falsa promessa para livrar-me de um problema" poderia ser universalizável. Para Kant, não poderíamos querer que uma mentira, no caso, uma falsa promessa, torne-se lei universal, tendo em vista que, do contrário, não poderia sequer haver uma promessa (que requer ser verdadeira), sendo assim que, caso se tornasse lei, essa máxima destruiria a si mesma ${ }^{79}$.

A Lei Universal liga-se a um elemento importante ainda não mencionado na ética kantiana: a noção de boa vontade. "Neste mundo, e até também fora dele, nada é possível pensar que possa ser considerado como bom sem limitação a não ser uma só coisa: uma boa vontade ${ }^{\Perp 80}$. Assim Kant abre a primeira seção da Fundamentação da Metafísica dos Costumes. Os talentos e as virtudes da linha aristotélica, ao contrário, não têm valor em si mesmos. O que lhes pode dar algum valor é somente a orientação para uma boa vontade, visto que eles podem ser usados com uma má intenção. Mesmo a felicidade só é digna quando tem por base a boa vontade. Também as ações têm seu valor não pelas boas consequências que possam gerar, mas por se orientarem por uma boa vontade.

O que, porém, constitui uma boa vontade? É a vontade direcionada ao dever; ou seja, o dever como guia da vontade. Porém, orientar a vontade pelo dever não significa uma mera submissão da vontade, pois é ela que dá leis a si mesma. A moralidade, portanto, não consiste em leis externas orientando o indivíduo, visto que a própria vontade dá-se leis que orientam a ação. A autonomia da vontade, a sua capacidade de dar leis para si mesma, é o que fundamenta a moralidade em Kant. O que não significa arbitrariedade nas leis morais, haja vista que as leis se pautam pelo que a razão reconhece como bom, e que é universal - vale para todo ser racional. A vontade estipula leis na forma de mandamentos para guiá-la, mandamentos esses que a razão objetivamente reconhece como praticamente necessários, ou seja, que a razão reconhece como bom. Quando a razão determina a vontade de um modo infalível, ou seja, a vontade quer somente aquilo que a razão julga como bom, independente das inclinações, as ações são aí objetivamente reconhecidas como necessárias (conforme a razão) e subjetivamente necessárias (porque é assim que a vontade se orienta, sempre de

\footnotetext{
${ }^{79}$ Ibidem, p. 35 [BA 19].

${ }^{80}$ Ibidem, p. 21 [BA 1].
} 
acordo com a razão $)^{81}$. Todavia, não é o caso do ser humano atingir a plena coincidência da vontade com a razão, visto que a sua vontade está como encurralada pelas inclinações, as quais impelem as ações para diversas direções, dificultando seguir o que a razão estipula e reconhece como bom. Nesse caso, as ações são objetivamente (razão) necessárias (pela razão), porém subjetivamente contingentes (pela vontade), e a conformidade entre razão e vontade, em vez de dar-se por necessidade, dá-se por obrigação. Assim, é preciso haver "móbiles" que impulsionem a vontade a agir de acordo com a lei moral. Tais "móbiles" são os denominados mandamentos ${ }^{82}$.

Portanto, no que concerne aos humanos, na ética kantiana a vontade estipula mandamentos pelos quais se orientam as ações. Tais mandamentos têm a forma de um imperativo. O imperativo que concerne à ética é o imperativo categórico, que se distingue do imperativo hipotético. O imperativo hipotético se caracteriza por fórmulas do tipo "Se queres x, então deves y", como "Se queres ter um bom condicionamento físico, então deves fazer exercícios". São formas de obrigação, mas com vistas a outro fim. Todavia, o dever moral deve valer por si mesmo e incondicionalmente, não por um fim, numa contingência; somente assim é um imperativo categórico. Seu valor consiste na intenção boa, ou seja, na orientação pela boa vontade, independentemente dos resultados da ação.

Como dissemos, Kant traz princípios que orientam a ação moral, em vez de determinar deveres específicos. Tais princípios são apresentados na forma de um imperativo categórico, do qual Kant faz quatro formulações. A primeira formulação é a mencionada fórmula da lei universal. “Age apenas segundo uma máxima tal que possas ao mesmo tempo querer que ela se torne lei universal"; e na versão da fórmula da lei da natureza. "Age como se a máxima da tua ação se devesse tornar, pela tua vontade, em lei universal da natureza" ${ }^{\prime 3}$. Ela garante que as leis que orientam a vontade não valham somente para si, e sim para todas as vontades; é uma lei que deve valer necessária e universalmente, como uma lei de natureza. A segunda fórmula do imperativo categórico é a que coloca a humanidade como fim em si mesma: "Age de tal maneira que uses a humanidade, tanto na tua pessoa como na pessoa de qualquer outro, sempre e

\footnotetext{
${ }^{81}$ Ibidem, p. 50 [BA 36].

${ }^{82}$ Ibidem, p. 50 [BA 37].

${ }^{83}$ Ibidem, p. 62 [BA 52].
} 
simultaneamente como fim e nunca simplesmente como meio" ${ }^{84}$. Temos aí a importante noção de pessoa, uma noção moral que se refere ao valor em si mesmo do ser racional. O ser racional, enquanto pessoa, é digno de respeito, nunca deve ser tomado somente enquanto meio, e sempre como fim. Vemos que Kant reconhece que por vezes os indivíduos têm de ser tomados como meio, no entanto, o preceito que comanda que eles devem sempre ser considerados como fim, dignos de respeito, procura impedir uma má disposição da pessoa, como numa manipulação a um fim que não convém a sua condição de pessoa. Deve-se o respeito pela pessoa, tanto a pessoa do outro quanto a de si próprio; isso implica que não só há deveres para com os outros mas também para consigo mesmo.

O filósofo analisa alguns casos sob o mencionado princípio, como o caso do suicídio e o da falsa promessa. Quem procurasse se matar deveria verificar primeiro se isso conviria com a ideia de humanidade da pessoa enquanto fim em si mesma. Alguém poderia escolher o suicídio querendo fugir de uma vida de penúrias, porém nisso estaria utilizando a sua pessoa como mero meio a esse fim para se livrar de um sofrimento. Por isso, segundo Kant, à luz dessa fórmula do imperativo, o suicídio é condenável, visto que o suicida toma a sua pessoa apenas como meio; o que nos faz ver que, na ética kantiana, o indivíduo não pode dispor de si mesmo como quiser ${ }^{85}$. Já na falsa promessa, toma-se a pessoa de outrem como mero meio, em vista de um fim que não a leva em consideração $^{86}$. Nesses dois casos vemos que a humanidade da pessoa de um ser racional não foi respeitada e levada em consideração sempre como um fim. Tem-se assim, como exigência, uma sacralidade no ser humano, dado que ele é um ser racional e, dessarte, pessoa, cuja humanidade deve ser tomada sempre enquanto fim.

Como terceira fórmula do imperativo categórico, temos o agir de modo que "a vontade pela sua máxima se possa considerar a si mesma ao mesmo tempo como legisladora universal" ${ }^{\prime 87}$. Aqui, assume-se a autonomia da vontade, que se vê como legisladora e único fundamento da moralidade. Ela deve legislar as leis morais a si mesma, leis que devem ser universais; é, portanto, vontade autolegisladora, deve-se submeter a leis das quais ela pode se considerar como autora e devem ser, de tal modo,

\footnotetext{
${ }^{84}$ Ibidem, p. 73 [BA 66-67]

${ }^{85}$ Ibidem, p. 73-74 [BA 67].

${ }^{86}$ Idem.

${ }^{87}$ Ibidem, p. 80 [BA 76].
} 
que valham universalmente. Com respeito a essa fórmula, Kant lança mão do artifício teórico do reino dos fins, uma comunidade ideal da qual fariam parte todos os seres racionais, que seriam ao mesmo tempo legisladores e submetidos à Lei. A vontade do ser racional deve legislar leis que valem para si próprio e universalmente, ou seja, para todos os seres racionais, levando-se em conta a humanidade da pessoa, não simplesmente enquanto meio, mas sempre como fim. $\mathrm{O}$ que vemos nisso é a vontade autolegislagora como fundante da moralidade; em outros termos, Kant fundamenta a ética na autonomia da vontade. É vontade livre que dá leis a si mesma. O filósofo fala em uma causalidade na vontade, cuja propriedade consiste na liberdade ${ }^{88}$, em um mundo inteligível, contrastando com a causalidade da natureza, em que não há liberdade. Se a razão especulativa não pode comprovar a liberdade, a razão prática pode postulá-la. Porém, o ponto que se deve salientar é que a normatividade da ética kantiana advém das leis que a vontade estipula a si mesma, leis que a razão reconhece como boas e universalizáveis, que levam em conta a pessoa do ser racional enquanto fim.

Diversas linhas do pensamento filosófico europeu foram influenciadas pela ética kantiana, entre as quais as teorias de Hegel, de Schopenhauer e dos filósofos conhecidos como neokantianos. Elas de alguma forma desenvolveram ou criticaram alguns pontos do sistema de Kant.

Uma crítica famosa que Kant recebeu com respeito a seu pensamento ético é o que antes chamados de "formalismo kantiano". Hegel é um dos primeiros exponentes dessa crítica. Embora concorde com Kant na autodeterminação da vontade como fundamento do dever, Hegel critica o vazio formal de um "dever pelo dever", este que consiste apenas na universalização sem contradição de uma máxima, segundo a primeira formulação do imperativo categórico. Com essa formulação, segundo Hegel, não se pode determinar concretamente quais deveres devem-se seguir e até se possibilita que ações imorais sejam realizadas sob esse critério ${ }^{89}$. Para Hegel, a vontade audetermina-se (como em Kant) e tem uma intencionalidade ao bem, mas que precisa de deveres concretos para se realizar. Esse campo subjetivo, da autodeterminação da vontade, tem

\footnotetext{
${ }^{88}$ Ibidem, p. 97 [BA 97]

${ }^{89}$ NERI, Demetrio. Filosofia Moral. Op. Cit., p. 196. Se poderia defender Kant alegando que, com as outras formulações do imperativo, tem-se sim uma maior concretude no que se refere ao dever, por exemplo, no critério de se levar em conta a humanidade da pessoa enquanto fim nas ações éticas, embora de fato não haja deveres específicos. Mas não nos demoraremos nisso aqui.
} 
relevância para a "moralidade", que Hegel distingue do que chama a "eticidade". Esta, segundo Hegel, concerne ao passo concreto, ao conjunto de normas que realizam o ethos de um povo; instituições tais como a família, a sociedade civil e o Estado são o que promovem a eticidade e especificam as normas que devemos seguir. As instituições, e em especial o Estado, garantiriam uma harmonia entre o interesse pessoal e a vontade geral $^{90}$. Em suma, é pelas instituições que a ética é garantida.

Schopenhauer, de uma via inteiramente diferente, também está em diálogo com o pensamento ético kantiano. Vimos que em Kant a liberdade e autonomia da vontade são postuladas pela razão prática, pois que ela não pode ser comprovada pela razão teórica, para poder fundamentar a ética; a vontade livre dá leis a si mesma. Isso advém da famosa distinção kantiana entre "coisa em si" e "fenômeno", sendo este o que podemos efetivamente conhecer por categorias, enquanto aquela (com a qual encontra-se vinculada a liberdade) está no âmbito do mundo inteligível, do qual apenas podemos especular, mas não conhecer. Em Schopenhauer mantém-se essa diferença entre "coisa em si" e "fenômeno"; no entanto, a coisa em si é o que está por trás de tudo que existe no mundo, dos fenômenos, e essa coisa em si é a Vontade ou, como ele a chama, Vontade de Vida. A Vontade, em Schopenhauer, é uma força cega que está por trás de tudo no mundo dos fenômenos, inclusive dos seres humanos, que apenas são um fenômeno entre outros ${ }^{91}$. Nas vidas humanas, aos ritmos da Vontade de Vida, vemos uma oscilação entre a dor e o tédio, o eterno querer de uma vontade que não se sacia e que cai no tédio quando não deseja. Como o ser humano é levado por essa vontade cega, não se poderia fundamentar uma moralidade na "autonomia da vontade", como Kant; por isso, Schopenhauer enxerga em um sentimento, a compaixão, o fundamento da moral ${ }^{92}$.

Max Scheler também formula a sua própria teoria ética em discussão com o pensamento ético kantiano. Em contraposição ao "formalismo" de Kant, Scheler busca formular uma "ética material" (especialmente em sua obra "O formalismo na Ética e a ética material dos valores", escrita entre 1913 e 1916). Scheler, assim como Kant, também acredita em obrigações éticas a priori, não relativas a consequências ou mesmo

\footnotetext{
${ }^{90}$ Ibidem, p. 197.

${ }^{91}$ SCHOPENHAUER, Arthur. O Mundo como Vontade e como Representação. Tomo I. Trad. Jair Barboza. São Paulo: Editora UNESP, 2005, p. 358-359.

${ }^{92}$ NERI, Demetrio. Filosofia Moral. Op. Cit., p. 199.
} 
à felicidade. No entanto, para se desviar do "formalismo", Scheler funda as obrigações nas intuições de valores e na noção de pessoa. Como já aludimos na seção "Eudemonia e virtudes", em Scheler as virtudes podem ser intuídas e se mostram a partir de formas de visualização, que não são intelectuais, mas emocionais, e que são fundamentalmente duas: o amor e o ódio. As classificações dos tipos de valores, desde os meramente prazerosos até os sacros, ou seja, dos menos elevados aos mais elevados, são dados $a$ priori, embora quais valores preencham essas classificações varie culturalmente. Nós, que podemos intuir valores, devemos agir de modo a promover os valores mais elevados. A pessoa - noção kantiana que Scheler retoma com certas modificações, mas mantendo sua sacralidade - é quem consegue perceber esses valores. A pessoa traz a marca da singularidade; cada pessoa tem seu modo de amar e, assim, de intuir valores, além de um valor próprio singular, pois que cada um é único. Dessa forma, não há o "bem em si", mas o "bem em si” para mim. A pessoa, agindo eticamente, percebe seu lugar no mundo e seus deveres para com o mundo e com os outros. O imperativo ético, em Scheler, não se refere ao que se deve fazer, mas ao que eu devo fazer ${ }^{93}$. A ética scheleriana, portanto, é uma ética dos deveres, mas que tem em vista a individualidade: é o que o indivíduo consegue perceber de sua função e integração ao mundo.

$$
* * *
$$

Depois dessa breve exposição de alguns dos traços marcantes das teorias éticas europeias tradicionais mais conhecidas, pode-se ver que seria muito complexo encontrar coincidências ou convergências entre elas, ou unificá-las num único sentido de ética, visto que essas teorias não apenas mostram elementos contrastantes, mas a própria compreensão do que seja ética em cada teoria não é única. O que poderia haver de convergente nessas teorias éticas? Esse ponto é relevante para nosso trabalho, porque se poderia perguntar qual de todas essas formas de conceber a ética é aquela pressuposta quando Heidegger declara que uma ética não é necessária à ontologia fundamental; em outros termos, poder-se-ia perguntar qual dessas éticas é rejeitada, tendo em vista que são muitas e apresentam características peculiares.

\footnotetext{
${ }^{93}$ DAVIS, Zachary \& STEINBOCK, Anthony.Max Scheler.Op. Cit.
} 
Como preparo para o segundo capítulo, podemos detectar nessas teorias éticas que foram expostas pelo menos três elementos que parecem comuns, apesar das diferenças entre as teorias; elementos que serão precisamente os fundamentais nas apreciações de Heidegger sobre a ética tradicional. Esses elementos podem ser considerados como convergências de todas as teorias éticas analisadas neste capítulo, o que será fundamental para qualifica-las enquanto tradicionais.

A primeira convergência se refere ao ser mesmo da ética, e está no pressuposto da própria existência da ética. Todas as teorias éticas tradicionais pressupõem, em seu ponto de partida, que a ética está aí; não apresentam qualquer dúvida a respeito da existência mesma da ética. As teorias éticas tradicionais procuram responder questões específicas e internas à ética, tais como a questão do que é bom, do que é correto, quais são nossos deveres; apontam para certos valores e indicam certas ações como corretas ou incorretas, ou mesmo detectam problemas que elas tentam resolver. Bom, mal, certo, errado, etc., são categorias que podem ser vistas, captadas racionalmente, sentidas por algum sentimento moral, porque se supõe que essas articulações são encontradas no mundo (Kant, Mill) ou nos humanos (Hume). Fatos ou atitudes morais são admitidos como se desvelando para determinados modos de visualização. Nas vicissitudes da realidade humana, as teorias éticas tradicionais encontram questões e possibilidades que podem ser analisadas eticamente, procurando entender como seria mover-se de acordo com certos valores, seguir orientações, realizar-se, etc. Não há em nenhuma das teorias éticas observadas uma dúvida acerca da existência mesma da ética.

A segunda convergência refere-se ao humano e reside no suposto de ser factível um ser humano ético capaz de levar adiante essas articulações morais e submeter-se a elas, de acordo com as exigências das diversas teorias. Para a realização da ética em sentido tradicional, há uma série de determinações do humano que sempre acabam se remetendo a uma série de propriedades. Esse ente humano é visto como agente racional, livre e responsável, como uma pessoa, seja esta virtuosa ou um animal egoísta, mas sempre como um animal de logos, capaz de seguir certos fins determinados, algum tipo de bem ou de prazer, ou de fuga do mal-estar, ou procurando a sua dignidade. Nas teorias éticas tradicionais parece pressupor-se em todo momento um ser humano determinado em seu ser mediante propriedades estáveis e constantes, a partir do qual se 
pode formular um dever-ser ético para determinar seu querer, como um fim a ser alcançado através de ações livres e responsáveis.

Por fim, através dessas atribuições e demandas vinculadas ao humano, todas as teorias éticas tradicionais requerem, para a sua constituição e desenvolvimento, a utilização de um certo tipo de temporalidade, uma temporalidade linear e, até certo ponto, previsível, sob a qual fazer promessas, honrar compromissos, administrar castigos, colocar deveres, lembrar ações passadas, reivindicar, desagravar, etc. As ações éticas em geral - sejam virtuosas, deontológicas ou contratuais - precisam dessa temporalidade pautada segundo as articulações tradicionais de passado, presente, futuro. O contrato é realizado no passado e tem ressonâncias atuais; o cálculo da maior felicidade do maior número precisa prever boas consequências para o futuro; as cobranças de ações passadas devem poder ser compensadas no presente; deveres $a$ priori e necessários devem valer em toda a linha do tempo, e assim por diante. Todas as teorias éticas tradicionais, a despeito de suas grandes diferenças, parecem utilizar esse mesmo tipo de temporalidade.

Resumindo: todas as teorias éticas tradicionais admitem que existe a ética e que há um ser humano capaz de realizá-la numa temporalidade linear. Precisamente, esses são os três pontos fundamentais da filosofia de Heidegger que terão direta incidência na rejeição da ética tradicional. Na sua filosofia, em primeiro lugar, a moralidade ética tradicional como fenômeno será questionada em sua raiz; em segundo lugar, será apresentada uma nova noção de humano como Dasein; e, finalmente, será formulada uma temporalidade originária da existência, não linear e não pautada pela tríade passado-presente-futuro enquanto espécies de divisões sucessivas do tempo. Esses serão os temas do nosso próximo capítulo. 


\section{CAPÍTULO 2.}

\section{Ser e Tempo de Heidegger: elementos existenciários para a rejeição da ética tradicional (Ontologia fenomenológica, Dasein, Temporalidade).}

Devemos agora expor alguns aspectos da ontologia fundamental e da analítica existenciária de Heidegger que sejam relevantes para entender as relações entre essa analítica e as teorias éticas tradicionais que foram expostas no capítulo anterior. Esses aspectos que serão examinados são fundamentalmente: a questão do ser dentro da apropriação da Fenomenologia, a nova concepção do humano e a questão da temporalidade. Neste capítulo apenas apresentaremos esses aspectos da filosofia de Heidegger que nos interessam para o presente trabalho, mas ainda sem mencionar as questões éticas. Nossa apresentação da filosofia de Heidegger se centrará principalmente em Ser e Tempo (1927), sendo por vezes mencionada alguma outra obra preferentemente da mesma época.

\subsection{Ontologia e Fenomenologia}

Heidegger começa Ser e Tempo declarando a necessidade de se retomar a questão do sentido do ser, questão cujo interesse, segundo ele, caiu no esquecimento. A pergunta pelo ser "não é uma questão qualquer", pois foi já foi abordada por Platão e Aristóteles, embora, ao longo da história da metafísica ocidental, teve apenas "retoques" e "desvios" e, finalmente, aquilo que "de modo fragmentário e numa primeira investida foi um dia arrancado dos fenômenos pelo supremo esforço do pensamento de há muito se trivializou"94. Formou-se um dogma acerca do ser, com base na interpretação grega da questão; dogma que declara "supérflua" a questão do sentido do ser e mesmo faz com que esta não seja sequer posta. Afirma-se nessa tradição que ser é o conceito mais universal e, assim, indefinível, mas que sequer carece de definição, porquanto nós o empregamos a todo o momento e o compreendemos desse modo.

Vê-se já que Heidegger põe-se diante da história da metafísica e quer reorientá-la. Para o filósofo, “a pergunta pelo sentido do ser não só não foi concluída, não só não se

\footnotetext{
${ }^{94}$ HEIDEGGER, Martin. Ser e Tempo. Trad. Fausto Castilho. Campinas: Editora Unicamp; Petrópolis: Vozes, 2012, p. 33 [2].
} 
formulou de modo suficiente, mas [...] caiu no esquecimento"95. A história da metafísica tem base na ontologia grega, mas essa ontologia que se herdou decaiu numa tradição e degradou-se a algo que, supõe-se, pode ser compreendido por si mesmo; isto é, as vicissitudes da história da metafísica ocidental levam a essa visão sobre o ser como evidente, compreensível por si mesmo. Ao longo de sua história, certos âmbitos ou regiões de ser (como Cogito, eu, sujeito, razão, pessoa) aparecem e passam a dominar a problemática da metafísica, encobrindo o ser. Isso podemos chamar de entificação do ser, ou seja, o transformar o ser em um ente. Esses âmbitos do ser cristalizados ao longo da história da filosofia são entes que foram, de algum modo ou outro, tomados como sendo o ser e ocupando seu lugar.

Heidegger vê, então, a necessidade de uma destruição [Destruktion] dessa metafísica; uma desconstrução de seu conteúdo pelo fio condutor da questão do ser, de modo a se mostrarem as "experiências originárias" em que brotaram as primeiras determinações do $\operatorname{ser}^{96}$. A destruição da metafísica dá-se por meio da noção de temporalidade, sendo que em seu diagnóstico a metafísica mal compreendeu o tempo e a sua conexão com o ser. A metafísica compreendeu o ser como uma simples presença, no modo da subsistência (Vorhandenheit), perdendo-se assim a sua dimensão temporal.

O ser tem seu próprio movimento, um movimento que faz com que ele não esteja simplesmente presente aí, como um dado de fácil acesso. O ser não está disposto à nossa frente, porquanto se desvela de vários modos e amiúde se camufla. Igualmente, ser é sempre ser dos entes, não algo que está fora, apartado deles. No entanto, o ser também não se resume ao ente. Nem mesmo pode ser considerado um ente, ainda que especial. "O ser do ente não 'é' ele mesmo um ente". Assim, ele requer um modo de acesso próprio, ou melhor, "exige uma maneira de se mostrar que lhe seja própria e que difira essencialmente da descoberta do ente" ${ }^{97}$. Dessa forma, é necessário para a questão do ser que se conquiste um seguro modo de acesso ao ser. Porém, como ser é sempre ser dos entes, precisa-se interrogar acerca do ser a partir dos entes.

\footnotetext{
${ }^{95}$ Ibidem, p. 85 [21].

${ }^{96}$ Ibidem, p. 87 [22].

${ }^{97}$ Ibidem, p. 43 [6].
} 
Há para Heidegger um método adequado para entrar na questão do ser, a saber, a fenomenologia. A fenomenologia é o como, o método que Heidegger emprega para tratar das questões em sua obra: o sentido do ser, a destruição da metafísica e a analítica existenciária. A fenomenologia nasce com Edmund Husserl dentro de um projeto de fundamentação das ciências. Enquanto as ciências tratariam de fatos, de um objeto "individual", "espaço-temporalmente existente", com determinada configuração, com características de determinados momentos ${ }^{98}$, a fenomenologia seria uma "ciência de essências", já que procura ver esse objeto em seu ser, não limitado ao que é dado faticamente (como objetos que poderiam ser de outro jeito, por sua própria essência; ou seja, objetos que podem se mostrar de variados modos) ${ }^{99}$. Para isso, é preciso realizar uma epoché, uma "redução", um colocar "entre parênteses" o mundo, em vista de que as coisas que se nos apresentam possam ser vistas em sua essência. Contra uma tendência teorética de explicar as coisas a partir de uma abordagem pressuposta, a fenomenologia de Husserl se apresenta como um método descritivo, que procura visualizar seu objeto de investigação tal como aparece - "ir às coisas mesmas", como diz seu lema.

As "coisas mesmas" são, segundo Husserl, os fenômenos que se apresentam à consciência. Porém, não se trata de passividade, pois que a consciência, em vez de mero receptáculo, é um ato: consciência é sempre consciência de algo. Os atos da consciência são denominados intencionalidades. A maneira como a consciência intenciona o objeto não é meramente cognitiva; odiar, amar, temer, aprazer-se, imaginar, recordar, etc. são formas diferentes de se visarem as coisas. A intencionalidade da consciência e a doação do objeto estão sempre conectadas; sempre viso o objeto de determinada forma e ele, por sua vez, doa-se a mim. Denomina-se fenômeno aquilo que é doado à consciência. Mas os fenômenos não são meras representações do objeto, ou mesmo algo que me aparece enquanto a coisa mesma, seu ser, esconde-se ou mantém-se oculto. O que se mostra, ou seja, o fenômeno, é o próprio ser da coisa. Contudo, o fenômeno não se dá todo, pois que aquilo que aparece é apenas um setor de uma série de aparições, enquanto outras séries encobrem-se, sendo que o que se desvela pode ocultar-se e o oculto pode revelar-se (por exemplo, no caso da percepção visual, uma forma de

\footnotetext{
${ }^{98}$ HUSSERL, Edmund. Ideias para uma Fenomenologia Pura e para uma Filosofia Fenomenológica. Trad. Márcio Suzuki. São Paulo: Ideias \& Letras, 2006, p. 34.

${ }^{99}$ Ibidem, p. 35.
} 
intencionalidade: quando olhamos para um livro fechado, não intencionamos as suas páginas; se o abrirmos, não vemos sua capa). O ser das coisas, o fenômeno, pode sempre se apresentar de vários modos e aspectos.

Dessarte, uma maçã pode se apresentar enquanto percepção sensitiva (visão ou paladar, por exemplo), uma imagem (foto, desenho), uma recordação; assim como ela pode ser intencionada por nossa consciência como uma fruta, um sabor aprazível ou desagradável, um recordar, etc. Porém, o modo como temos essa relação com a maçã se dá na orientação natural, em que estamos a maior parte das vezes, vivendo nossa vida normalmente, junto aos objetos, às pessoas, em certas situações e ambientes. Isso também inclui as ciências, pois que nelas também se tem a coisa como "estando aí" na efetividade, como algo real que há no mundo $^{100}$. É na orientação natural que as coisas se apresentam à nossa consciência e esta as intenciona. A fenomenologia de Husserl se interessa pela descrição de como isso acontece numa orientação fenomenológica, que consiste numa reflexão sobre nossa atitude natural, sobre as intencionalidades e o mostrar-se dos fenômenos que ocorrem aí. A existência efetiva da coisa (por exemplo, da maçã) é posta em suspenso, "entre parênteses"; ou seja, não está em questão se o objeto de análise existe realmente ou não. Realiza-se uma epoché com o que é próprio da orientação natural na redução fenomenológica, um "colocar entre parênteses", para se observar como ocorre a correlação intencionado-intencionalidade na consciência. Ao se colocar fora de questão a "tese geral" da orientação natural, de que as coisas estão aí na efetividade ${ }^{101}$, "não nego este "mundo"” nem "duvido de sua existência", mas realizo uma redução, o que "me impede totalmente de fazer qualquer juízo sobre existência espaço-temporal" $" 102$.

Heidegger - que trabalhou com Husserl como professor ajudante e lhe dedica sua principal obra, Ser e Tempo - apropria-se da fenomenologia de uma forma que descontenta Husserl, que não enxerga a princípio seu trabalho como genuinamente fenomenológico. O que mais interessa na fenomenologia para Heidegger é a questão do mostrar-se do fenômeno, que tanto se desvela como se oculta. Heidegger conecta a fenomenologia com a ontologia, e especificamente com a questão do sentido do ser,

\footnotetext{
${ }^{100}$ HUSSERL, Edmund. Ideias para uma Fenomenologia Pura e para uma Filosofia Fenomenológica. Trad. Márcio Suzuki. São Paulo: Ideias \& Letras, 2006, p. 77.

${ }^{101}$ Ibidem, p. 78 .

${ }^{102}$ Ibidem, p. 81.
} 
como um novo método para abordar a questão da ontologia, já que tal abordagem não pode se pautar pela tradição, pois esta permitiu, precisamente, o esquecimento da questão do sentido do ser. Heidegger sugere, assim, um novo significado para o termo "ontologia", que a desconecta de alguma disciplina filosófica com esse nome. Procura ver não as exigências de alguma disciplina dada, mas o modo de tratamento e o perguntar determinado pelas próprias necessidades das coisas, partindo das demandas das coisas mesmas; ${ }^{103}$ no caso, o modo de tratamento demandado pelo ser. Dessarte, a ontologia é a tentativa de trazer à tona o ser do ente e compreender o ser mesmo; e é aí que entra a fenomenologia, para fazer jus ao seu lema - "ir às coisas mesmas" procurando ver seu objeto de investigação, o ser, em sua necessidade, em seu próprio movimento, em seu mostrar-se.

Decompondo o termo "fenomenologia", temos do grego os termos phainómenon e lógos. Phainómenon, "fenômeno", tem várias acepções, porém a mais originária é "aquilo que se mostra". Fenômeno, portanto, tem a ver com o mostrar-se. No entanto, esse mostrar-se originário não quer dizer plena clareza; o ente pode se mostrar no modo como ele não é realmente, ou seja, no parecer, na aparência. Também pode haver uma manifestação, algo que aparece, mas que aponta na verdade para algo encoberto, que é o que verdadeiramente se mostra embora não apareça (como, por exemplo, os sintomas são a manifestação de uma doença). Faz parte do mostrar-se originário, ao qual Heidegger denomina fenômeno, não só o desvelar, o aparecer, mas também o velar-se, o parecer, o manifestar-se. Por seu turno, lógos, dos diversos sentidos da palavra, tomamos como fundamental o significado de "discurso", no sentido de tornar manifesto, fazer ver. Seria assim um fazer ver no dito aquilo de que se discorre no discurso ${ }^{104}$.

Fenomenologia em Heidegger, portanto, é um "fazer ver a partir dele mesmo o que se mostra tal como ele por si mesmo se mostra"105. Sua fenomenologia quer buscar aquilo que não se mostra de imediato ou mesmo permanece oculto por trás do que se mostra, sendo que amiúde ele não somente está ligado ao que se apresenta de imediato como que o funda e dá seu sentido. O que viria a ser esse fenômeno? O próprio ser dos entes. "Ele pode estar tão amplamente encoberto que fica esquecido e já não se faz a

\footnotetext{
${ }^{103}$ HEIDEGGER, Ser e Tempo. Op. Cit., p. 101 [27].

104 Ibidem, p. 113 [32].

${ }^{105}$ Ibidem, p. 119 [34].
} 
pergunta por ele e por seu sentido"106 - o que Heidegger enxergou na tradição metafísica acerca do sentido do ser. Fenômeno, na fenomenologia de Heidegger, consiste no ser; e a sua fenomenologia é uma fenomenologia do ser.

Procura-se, então, com a fenomenologia, investigar o ser. Todavia, como o ser é sempre ser dos entes, é preciso também acessar de modo adequado o ente. Que ente? Heidegger considera o Dasein como o ente assinalado para se acessar ao ser. "Dasein" é o termo que designa o humano. O Dasein é tematizado mais especificamente na próxima seção; aqui o Dasein aparece apenas como ente assinalado dentro da pergunta pelo sentido do $\operatorname{ser}^{107}$. Em Hermenêtica da Facticidade, Heidegger usa esse termo para evitar toda uma concepção filosófica e teológica que termos como "homem" e "pessoa" carregam $^{108}$, assim como outros termos que vêm carregados de propriedades que procuram definir o humano ${ }^{109}$. Em Ser e Tempo, Heidegger quer se afastar disso. O Dasein, segundo Heidegger, em vez de ter propriedades que definem seu ser, é um ente que tem-de-ser, ou seja, que não está determinado, mas constitui seu ser a todo o momento. Portanto, "Dasein" não é simplesmente um novo termo que se refere ao ser humano, mas também (sobretudo talvez) ao seu modo de ser, modo que o torna singularmente apropriado para abrir ao ser numa fenomenologia do ser.

O Dasein, como veremos em seguida, revelar-se-á como tendo variados modos de ser, que são formas que apontam para diferentes relações com o ser que o Dasein pode ter. O Dasein está aí em meio aos entes, e nesse movimento tem uma certa compreensão do ser, dos outros entes e de seu próprio ser $^{110}$. Procuraremos trazer um exemplo para tentar esclarecer: se sou um estudante (ou seja, faço-me assim, pois que posso não sê-

\footnotetext{
${ }^{106}$ Ibidem, p. 121 [35].

${ }^{107}$ Dasein é o termo que Heidegger utiliza para designar tanto o ser humano quanto seu modo de ser. No alemão, o termo Dasein é acompanhado pelo artigo neutro das, não havendo, portanto, uma marcação de gênero feminina ou masculina. Em português, não há um artigo propriamente neutro, pois que se confunde com o mesmo signo do artigo masculino: $o$. Se houvesse um artigo destacadamente neutro na língua portuguesa, usá-lo-íamos neste texto. Porém, como não o há, optamos pelo uso do artigo $o$ antecedendo o termo Dasein, em vez de utilizar o termo sem a antecedência de um artigo (não usual no português), o que se poderia fazer buscando-se evitar indicar um gênero específico. Obviamente, Dasein, mesmo que antecedido pelo artigo $o$ possa parecer "masculinizado", refere-se a todos os gêneros humanos. De qualquer maneira, com ou sem artigo, esse termo aparecerá adjetivado em alguns momentos do texto (por exemplo, Dasein angustiado), o que inevitavelmente levaria a nos posicionarmos por alguma escolha de gênero no adjetivo que o acompanhasse.

${ }_{108}$. Ontologia. Hermenêutica da Facticidade. trad. Renato Kirchner. Petrópolis: Vozes,

2012, p. 37. A noção de facticidade será elaborada mais à frente.

${ }^{109}$ Ibidem, p. $28-29$.

${ }^{110}$ Ibidem, p. 59 [12].
} 
lo), tenho uma certa compreensão de meu ser enquanto estudante e do ser de outros entes, como lápis, livros, computador, que estão em minha volta para meu estudo. Posso não ter conhecimento da composição química do meu lápis, nem de todos os detalhes do hardware do meu computador; porém, sei usá-los para o meu dia-dia de estudante, sendo isso uma forma como compreendo seu ser e também me compreendo enquanto estudante. Ter compreensão do ser e do ser de outros entes, ou seja, compreender de alguma forma diversos modos de ser, é próprio ao Dasein, o que o torna "abertura ao ser”. É por isso apropriado tomá-lo como via para a pergunta pelo sentido do ser. No entanto, como ser é sempre ser dos entes, há que procurar algum ente que melhor encaminhe a investigação do sentido do ser. O Dasein se apresenta como esse ente, visto que em seu modo de ser ele compreende a si mesmo, seu ser e o ser de outros entes. O Dasein, na medida em que se faz a si mesmo, tem uma certa compreensão de ser, ou, como veremos, uma pré-compreensão (uma compreensão prévia).

Como se parte da análise do Dasein, o logos da fenomenologia, o fazer ver aquilo que se mostra, tem o caráter de um hermeneuein, de um compreender: e é por ele que se anuncia o ser e as estruturas ou modos de ser do Dasein; em outras palavras, o Dasein compreende a si mesmo e ao ser. Mas nesse ato de compreensão, a fenomenologia devém hermenêutica ${ }^{111}$. Por conseguinte, temos em Heidegger uma fenomenologia hermenêutica. Ela se pauta no próprio modo de ser do Dasein, que tem certa compreensão do ser na medida em que está aí, lidando com os entes e consigo mesmo. Não é, então, colocando o mundo "entre parênteses", como na fenomenologia husserliana, que se investiga o fenômeno do ser, mas na análise existenciária do Dasein, o ente que tem uma compreensão do ser pelo seu próprio modo de ser. Uma hermenêutica do Dasein, uma fenomenologia dos modos de ser próprios desse ente peculiar, é necessária, pois, para se pôr a questão acerca do sentido do ser.

Por que o ente humano haveria de ser investigado, sendo ele um ente particular e não devendo o sentido do ser em geral reduzir-se a nenhum ente? Já adiantamos um pouco o que faz o Dasein ter a precedência ou primado na questão do ser, baseado em seu caráter de compreensão, de ser compreensivo. Todavia, Heidegger traz outras razões que apontam para esse primado. Algo que primeiro destaca o Dasein diante de outros

${ }^{111}$ Ibidem, p. 127 [37]. 
entes é o próprio perguntar pelo sentido do ser; o Dasein é o ente que tem como uma de suas possibilidades de ser a de perguntar, de modo que fazer "expressamente e de modo transparente a pergunta pelo sentido de ser" exige que se faça "uma adequada exposição prévia" do Dasein "quanto ao seu ser" ${ }^{\prime 12}$. Todavia, isso não é suficiente; ainda não se mostrou propriamente a sua precedência. Não se trata apenas do perguntar. O Dasein traz um vínculo mais forte com o ser; em sua própria estrutura, em sua existência, afirmará Heidegger, está envolvido já na questão o ser. “O Dasein não é um ente que só sobrevenha entre outros entes. Ao contrário, ele é onticamente assinalado, pois para esse ente está em jogo em seu ser esse ser ele mesmo"113. O Dasein nunca se definiria em uma determinada forma de vida, em algum tipo de identidade (ser padeiro, professor, amigo do João, leitor erudito, brasileiro, etc.), nem tem uma essência que o define e dita o que ele é. O Dasein tem uma compreensão de outros modos de ser, tem um vínculo peculiar com o ser: não só compreende existenciariamente seu ser, em suas vicissitudes marcadas pela possibilidade de ser, como tem uma compreensão do ser de outros entes, uma compreensão que se dá em seu existir. Por essa sua forma de entender o ser de outros entes, o Dasein também é condição de possibilidade das outras ontologias, dos modos de ser dos outros entes, pois é o único ente que compreende modos de ser diversos do seu. E por isso o Dasein tem também uma certa compreensão do ser em geral. A analítica existenciária torna-se a ontologia fundamental ${ }^{114}$.

Porém, como acessar o Dasein? Vimos que o método de Heidegger é fenomenológico, num sentido próprio e diferente do husserliano, método com o qual almeja fazer ver aquilo que se mostra a partir de si mesmo, procurando evitar, assim, algum pressuposto teórico ou metafísico. E como é que o Dasein se mostra? O Dasein se apresenta antes de tudo no modo que lhe é mais próximo, modo pelo qual ele se apresenta no mais das vezes, isto é, em sua cotidianidade mediana ${ }^{115}$, no modo como o Dasein se apresenta na maior parte das vezes em seu dia-a-dia. Entretanto, da cotidianidade não se deve extrair o que é meramente fatual, ou seja, ocasional e acidental, e sim as suas estruturas essenciais, as quais são os denominados existenciários [Existenzialen]. Dessarte, vemos Heidegger em Ser e Tempo fazer esse jogo no qual se visualizam o lado cotidiano do Dasein e daí se depreendem as estruturas

\footnotetext{
112 Ibidem, p. 47 [37].

${ }^{113}$ Ibidem, p. 59 [12].

${ }^{114}$ Ibidem, p. 63 [13].

${ }^{115}$ Ibidem, p. 73 [16].
} 
da existência. Entramos aqui na segunda dimensão do pensamento de Heidegger que terá suma importância em nossa investigação de uma metaética heideggeriana: a concepção existenciária do humano.

\subsection{O Dasein e os existenciários}

Existência é o que caracteriza o Dasein; isto é, a "essência" do Dasein consiste na existência ${ }^{116}$; porém, "essência" tem de aparecer entre aspas, pois na tradição filosófica da que Heidegger quer se afastar, essência marca o quid, a natureza de algo, ou seja, um conjunto de propriedades subsistentes que definem, delimitam e congelam o que o ser humano é. Pelo contrário, a existência não tem uma massa ou um conteúdo, é um vazio, ou melhor, é possibilidade. Ele não é marcado pela constância que a palavra "essência" pode sugerir, pois o Dasein é um constante ter-de-ser, modo de ser que aponta para um tipo de ente que não pode ser entendido como fixo, constante ou inalterável. O Dasein tem de ser seu ser, nunca o é simplesmente, seu ser está sempre em jogo do poder-ser; não sendo nada determinado, o que o Dasein vê a sua frente é pura possibilidade de ser. O Dasein tem de ser a todo o momento o ser que ele pode ser. É também, em termos de Heidegger, transcendência, pois que sempre ultrapassa aquilo que é em direção a outras possibilidades de ser. O Dasein pode fazer-se um ser que sempre transcende.

Dessarte, a existência de que nos fala Heidegger não é a existentia no sentido do termo latino próprio da ontologia tradicional, que designa uma pura subsistência [Vorhandenheit], como quando se fala que existe uma saída ou uma janela, ou seja, um modo de ser que não é o modo de ser do $\operatorname{Dasein}^{117}$. Existência aplicado ao Dasein refere-se a Ek-sistere, a um "estar fora" que aponta para uma abertura, para um sair fora dos limitados estados fatuais e abrindo-se para possibilidades. O Dasein é sempre projeto de ser transcendendo o que é, ou melhor, o que aí está. O Dasein não apenas é, mas tem de ser, é projeto de ser, sempre um ser-possivel. Isso significa que qualquer tipo de influência, seja sociológica ou biológica, não é determinante no Dasein. O Dasein nunca pode se prender a um dado subsistente, pois seu caráter de poder-ser faz com que as possíveis determinações passem pelo crivo do ter-de-ser, de modo que não

\footnotetext{
116 Ibidem, p. 139 [ 42].

117 Idem.
} 
de fato determinações fundamentais; o Dasein pode lidar de variados modos com as influências biológicas ou sociológicas. Qualquer caracterização sociológica, cultural ou biológica do Dasein não toca em sua essência.

O ser que está em jogo na existência é sempre, em cada caso, o meu, um ser singular e intransferível que ninguém pode ser por mim. Isso implica que o Dasein, por ser sempre o meu, nunca pode ser considerado ontologicamente como um caso exemplar de um gênero. O Dasein é, lembrando uma expressão de Kierkegaard, "singular singularíssimo", o ser possível que tem de ser é sempre o meu. Podemos dizer que o Dasein é próprio de cada um, Dasein singular $^{118}$. Mas, apesar disso, o Dasein constantemente acaba caindo nas possibilidades dadas e limitadas pela cotidianidade mediana ${ }^{119}$, em lugar de achar a sua singularidade mais singular. O Dasein se identifica e se faz a si mesmo de acordo com as possibilidades que se encontram em seu dia-a-dia, como, por exemplo, as determinações de cultura, família ou dos papeis sociais que desempenha, possibilidades que herdamos de alguma tradição, de valores familiares, condição social etc.. O Dasein próprio, em suas possibilidades mais próprias, em seu poder-ser que mais originariamente o caracteriza, teria de ser assumido. Mas este ser mais próprio não é uma característica subsistente, uma massa densa que preencheria o Dasein e o definiria. Mesmo seu ser mais próprio tem de ser assumido e realizado pelo Dasein. Porém, no mais das vezes, o Dasein se faz a si mesmo na cotidianidade mediana, e em vez de fazer-se no modo da propriedade, assumindo a existência à qual é chamado, perde-se a si mesmo, ou se ganha somente na aparência, no modo da impropriedade $e^{120}$.

Vimos que Heidegger quer metodologicamente partir da cotidianidade mediana por esta ser o modo no qual o Dasein se encontra na maior parte das vezes. Isso significa que quase regularmente o Dasein não assume a si mesmo sua existência própria; ao contrário, movimenta-se no modo da impropriedade. Mas o que significa assumir a si próprio, sua existência, seu ser-aí? Significa assumir uma relação mais autêntica com sua essência, com seu próprio Dasein, com seu mais próprio poder-ser. O que isso vem a ser ainda não está claro, pois que se tem muito chão a se percorrer para

\footnotetext{
${ }^{118}$ Ibidem, p. 141 [42].

${ }^{119}$ Idem.

${ }^{120}$ Idem [43].
} 
que se possa compreender. Não se trata de um estado a ser atingido, mas de um processo temporal. O ponto importante antes disso é que tanto o assumir-se a si mesmo como o perder-se, tanto a propriedade quanto a impropriedade, fazem parte do modo de ser estruturador do vir a ser do Dasein, do que Heidegger chama ser-no-mundo.

Ser-no-mundo é um existenciário, assim como Dasein e como outros que se apresentarão a seguir, tal como expostos em Ser e Tempo. Um existenciário não é uma categoria em sentido tradicional, ou seja, um tipo de propriedade subsistente que define alguma coisa em seu conteúdo, mas uma constituição de ser do Dasein $^{121}$, uma estrutura aberta. Ser-no-mundo também não indica algo como uma localização, que o Dasein está localizado "dentro de" um mundo. Ser dentro de outro ente é uma faculdade dos entes que não tem o modo de ser do Dasein, de entes meramente subsistentes. Ser-em na expressão "ser-no-mundo" alude antes a um "habitar", a um "estar familiarizado", a um "cultivar"; o ser-no-mundo move-se e lida com as coisas com certa familiaridade. O Dasein tem um trato habitual com os entes que lhe vem de encontro. E o que é este "mundo" do ser-no-mundo? É uma totalidade existenciária, temporal, que, no entanto, pode-se analisar em momentos, para melhor apresentação. Assim, na expressão "ser-nomundo", temos o "ser" (ou “quem"), o "mundo" e o "no" (ou “em") ${ }^{122}$.

Mundo não é um local, um espaço; pois o Dasein tem a sua espacialidade própria, existencializada, que não consiste numa demarcação física de um ponto no espaço. Mundo abrange o que se apresenta ao Dasein em seu mover-se. São entes do-interiordo-mundo o que lhe aparece, entes com os quais o Dasein se ocupa. Mas, se se procura investigar a cotidianidade do Dasein, temos que verificar que entes do interior do mundo se apresentam no mais das vezes em seu cotidiano. São aqueles que estão no mundo mais próximo do Dasein cotidiano, no seu mundo-ambiente. O que me vem de pronto no meu mundo-ambiente, ou seja, que entes vêm de encontro ao Dasein cotidiano? Lápis, cadeiras, livros, canecas, em suma, entes no modo de ser do utilizável $[\text { Zuhanden }]^{123}$. As coisas que nos aparecem de imediato são aquelas no modo de um "para-quê", de uma serventia nas nossas vidas cotidianas. São coisas que utilizo, entes

\footnotetext{
${ }^{121}$ Ibidem, p. 145 [44].

122 Ibidem, p. 169 e 171 [53].

${ }^{123}$ Ibidem, p. 213 [69].
} 
que estão à mão. Assim, antes de ser um objeto de conhecimento, na forma da subsistência, o ente que me aparece é um ente utilizável, ou seja, em vista de um uso.

Tudo nos aparece dentro de uma rede de remissões, de um todo do qual o utilizável aparece enquanto tal: uma árvore pode me aparecer como um ponto para me encostar e me refrescar à sombra, junto com o livro que tenho em mãos e meus óculos de leitura, tudo isso remetendo ao meu lazer; e essa mesma árvore pode aparecer como uma madeira boa para a produção de um móvel, este que servirá na mobília de uma casa; farinha, ovos e chocolate para fins de produzir um bolo, este que será dividido entre amigos numa reunião. O utensílio, então, aparece ao Dasein de um modo não temático, mas em seu uso, dentro de uma rede de remissões que lhe dá o caráter da sua serventia. O trato que o Dasein tem com esses entes é denominado por Heidegger de ocupação [Besorgen], um traço ontológico que abrange todo e qualquer lidar com entes que não têm o caráter do Dasein. Não somente a relação mais próxima que o Dasein estabelece com os entes se dá nesta utilizabilidade, mas que o Dasein, como ser de possibilidades, já se movimenta em um mundo em que se apresentam possibilidades fatuais; já há um delineamento sobre as direções que se possam tomar, sobre quais possibilidades seguir.

Mas também nos encontramos no mundo com outros entes que têm o modo de ser do Dasein. Já a nossa relação com os entes que não são Dasein remete-nos inevitavelmente aos outros Dasein ${ }^{124}$. Por exemplo, andamos num campo que pertence a alguém, faz-se um sapato sob medida para certo consumidor, o bolo é para o aniversário de um sobrinho, etc. Isso porque o Dasein está aí junto aos outros. Não somente com entes utilizáveis ou subsistentes, mas também com outros entes que estão no mundo, que são-no-mundo, que estão aí; em suma, outros seres com o modo de ser do Dasein. Todavia, esse estar com os outros não consiste numa localização ou no mero fato de outros estarem presentes ou numa situação de subsistência, de haver presentes outros entes do caráter da existência. Ser-com outros é um existenciário. Não estou encapsulado dentro de um "eu" destacado e isolado que depois enfrente o problema de ter de se encontrar com outros. O ser-com é um existenciário e, dessa forma, abarca

\footnotetext{
${ }^{124}$ Ibidem, p. 341 [117].
} 
todas as formas ônticas de estar com os outros, desde a mais plena comunhão até o total isolamento.

O Dasein movimenta-se no mundo a partir das redes de significado que o orientam em seu fazer-se e lidar-se com as coisas, também englobando o outro com o qual desde já compartilha o mundo. Portanto, o "mundo do Dasein é mundo-com"125. Se, então, os outros com quem compartilho o mundo não são e nem podem ser no modo da subsistência ou da utilizabilidade, não é pela ocupação que se dá em meu lidar com eles, mas pelo que Heidegger chama a preocupação [Fürsorgen $]^{126}$. Preocupação com os outros é aqui entendida ontológico-existenciariamente; não tem o sentido habitual de ser atencioso com alguém. Ser atencioso é apenas uma forma da preocupação, assim como enganar, destruir, descuidar, ignorar. Como existenciário, não tem uma conotação negativa ou afirmativa e abrange todas as nossas relações com a alteridade, tanto as que se condenam quanto as que se elogiam, além de muitas outras sem qualquer conotação valorativa.

Dessarte, é visível que os outros não são algo que está fora de um eu que se destacaria do mundo; no mais das vezes, eu não me diferencio dos outros, e me movimento no mundo num modo impessoal que Heidegger denomina "Se" [Man], $a$ gente; nos movemos como a-gente se move. Este é outro existenciário. O existenciário a-gente é uma forma do ser si-mesmo afundado na cotidianidade. Falamos, ao salientar a essência do Dasein enquanto existência, de um ter de ser que é sempre meu, mas que muitas vezes esse si-mesmo do Dasein não é o escolhido, preferindo-se tomar a forma da impropriedade; em vez de assumir seu próprio Dasein, pauta-se pelas possibilidades demarcadas do cotidiano. Isso quer dizer que, enquanto Dasein, eu não projeto meu ser enquanto meu, e sim como a-gente projeta. E o que isso vem a ser? A-gente é um termo que se remete à impessoalidade: conversa-se sobre tal assunto como se conversa, vê-se determinado filme como todo mundo o vê, estudam-se determinados autores e assuntos relevantes porque todo mundo os está estudando, assiste-se a esportes que todo mundo está vendo, da mesma forma que se procura se distanciar da "massa" como se costuma distanciar-se, cultiva-se uma formação intelectual como e porque se cultiva; em suma,

\footnotetext{
${ }^{125}$ Ibidem, p. 345 [119].

${ }^{126}$ Ibidem, p. 351 [121].
} 
lida-se com os entes e consigo mesmo como se lida em geral, como todo mundo (agente) lida.

Apesar dessa constante preocupação do Dasein cotidiano de querer se distanciar dos outros e se diferenciar, ele vê suas possibilidades existenciárias podadas pelos outros que o colocam no chão das possibilidades cotidianas já traçadas. "Ele não é simesmo, os outros the retiram o ser. Os outros dispõem a seu bel-prazer sobre as cotidianas possibilidades do ser do Dasein"127. Quem são os outros? O quem aqui "não é este nem aquele, nem a-gente mesma, nem alguns, nem a soma de todos"; é, simplesmente, o neutro a-gente. "A-gente, que não é ninguém determinado e que todos são, não como uma soma, porém, prescreve o modo de ser da cotidianidade"128. Não se poder caracterizar o "quem" de a-gente; ele aponta para a impessoalidade. Nesse modo de ser, o Dasein não assume seu ser si-mesmo mais próprio, caindo no si-mesmo cotidiano. O Dasein, enquanto poder-ser singular, limita-se a possibilidades da cotidianidade, possibilidades já traçadas e, assim, estreitas, que encobrem outras.

A-gente é o si-mesmo do Dasein na cotidianidade mediana. Por que "mediana"? A mediania é um traço ontológico do existenciário a-gente. Trata-se do nivelamento das possibilidades na cotidianidade: suprime-se qualquer relevância que alguma possa ter sobre outra, elimina-se qualquer marco de diferença entre elas. "Toda precedência é silenciosamente nivelada. Tudo o que seja original é desbastado em algo de há muito conhecido. Tudo o que foi conquistado na luta passa a ser manuseado. Todo segredo perde sua força" ${ }^{2129}$. Como o Dasein cotidiano não assume seu si-mesmo mais próprio, mas o de a-gente, não segue uma existência autêntica, adentrando na inautenticidade. No entanto, segundo Heidegger, não é possível ser autêntico sempre, assim como nunca somos completamente inautênticos; a-gente, enquanto existenciário, caracteriza um modo de ser do Dasein, o que significa que é próprio do Dasein esse cair numa existência inautêntica. Ainda é cedo para um melhor esclarecimento sobre o que significa uma existência autêntica e assumir o si-mesmo. Há antes de explicitar em que consiste o próprio em do "ser-no-mundo".

\footnotetext{
${ }^{127}$ Ibidem, p. 363 [126].

${ }^{128}$ Ibidem, p. 365 [126].

${ }^{129}$ Idem [127].
} 
Do que se determinou acima sobre ser-no-mundo, encontramos entes no interior do mundo como entes utilizáveis, o quem do ser-no-mundo, o ser-com e a-gente. Todavia, talvez mais fundamental seja determinar o em. O modo como se está em um mundo, o ser-em, é vital para a caracterização de ser-no-mundo do Dasein. Já sabemos que o "em” de ser-no-mundo não significa uma localização, não é um "dentro" de algo. Ser-em, na verdade, é um traço ontológico do Dasein, não uma localização ôntica ou um ponto no espaço. Esse caráter de ser-em de ser-no-mundo está relacionado ao "aí" do Da-sein (ser-aí ou estar-aí). "O ente que é essencialmente constituído pelo ser-nomundo é cada vez ele mesmo o seu "ai""130. O que isso vem a dizer? O "aí" do Da-sein, ser/estar aí, significa abertura. Assim como o "em" de ser-no-mundo não significa localizar-se em um ponto no espaço, também não o é o "aí". Não é o mesmo que "aqui" ou "lá", que se referem aos entes do interior do mundo como utilizáveis; antes é pela abertura do "aí" que esses entes podem estar "aqui" ou "lá", visto que estão "aqui" ou "lá" em relação ao Dasein"131. Mas o que é essa abertura? Esta é o que possibilita os entes apresentarem-se ao Dasein, inclusive ele próprio. O Dasein é o ente que está aberto ao ser, é "aí" (ser-aí). Entenderemos isto melhor ao visualizarmos as suas diversas formas de aberturas (encontrar-se, compreender, discurso) e o modo como o Dasein se abre na cotidianidade, especialmente no modo que Heidegger chama de "decair".

Como nos encontramos no em do ser-no-mundo? Um primeiro ponto que podemos indicar é que estamos sempre em algum estado-de-ânimo [Stimmung]. Estado de ânimo é o termo conhecido em nosso cotidiano de um traço ontológico do Dasein, o existenciário que consiste no encontrar-se [Befindlichkeit $]^{132}$ num certo ânimo ou espírito. Estamos sempre em um estado de ânimo, mesmo quando dizemos que estamos indiferentes, que não estamos tristes nem alegres, nem ansiosos ou entediados, estamos sempre em um estado de ânimo. Por mais imperceptível que seja o estado de ânimo (nem todos são tão notáveis ou claros quanto o medo ou a alegria), o Dasein está sempre em um certo humor. Não só estamos sempre em um estado de ânimo, como que ele condiciona o modo como as coisas se apresentam a nós, inclusive o modo como o Dasein aparece para si mesmo. Na alegria tudo pode se apresentar numa espécie de

\footnotetext{
${ }^{130}$ Ibidem, p. 379 [132].

131 Idem.

${ }^{132}$ Ibidem, p. 383 [134].
} 
leveza; ou na tristeza solitária, em que tudo pode se apresentar como uma "inútil paisagem", tal como na música de Tom Jobim. Eles são formas de abertura que revelam o "aí" do Dasein, o ser-aí. "No ser do estado de ânimo, o Dasein, conforme ao ser do estado de ânimo, já está sempre aberto como o ente ao qual o Dasein foi entregue em seu ser como o ser que ele tem de ser existindo" ${ }^{133}$.

O estado de ânimo não é algo que vem "de fora" ou "de dentro", mas do próprio ser-no-mundo. O Dasein já sempre se abriu no ser-no-mundo com um estado de ânimo. Assim, ele é tão originário quanto qualquer outro existenciário. É uma forma de abertura que já está sempre aí pelo próprio fato de ser-no-mundo. Os entes que vêm de encontro ao Dasein vêm já nessa afinação do estado de ânimo. Vêm ao Dasein na forma de ser afetado pelo que vem de encontro. Assim, algo que lhe aparece, mostra-se como ameaçador, inútil ou utilizável, porque já previamente há essa abertura. É um tipo de abertura originária que se abre aos entes de um modo que uma suposta intuição pura não poderia. "Uma intuição pura, mesmo penetrando nas veias mais íntimas do ser de um subsistente, nunca poderia descobrir algo como ameaçador"134. Além disso, de sua parte, o olhar teórico, também uma abertura, é limitador. Ele toma o ente apenas como subsistente e o fixa a determinado modo de se apresentar, enquanto no estado de ânimo (que não se trata, mais uma vez, de um mero estado psíquico subjetivo) temos o "ver instável" pelo qual o ente utilizável se desvela de várias maneiras a depender do estado de ânimo ${ }^{135}$.

O encontrar-se é uma originária forma de abertura ao mundo do Dasein. Ele está sempre em um estado de ânimo, em cuja afinação os entes vêm de encontro. “Afinação", porque, se compararmos com a música, um instrumento pode produzir um som de diversas formas diferentes dependendo do modo como está afinado; analogamente, os entes se apresentam de tal ou tal forma sob uma afinação de um estado de ânimo. E algo importante nisso é que a abertura de um estado de ânimo pode apontar ao próprio ter-de-ser do Dasein, que costuma estar encoberto pelos limites das possibilidades cotidianas. Por mais que o Dasein esteja imerso na cotidianidade, um estado de ânimo pode abri-lo à sua existência mais própria. No entanto, o Dasein

\footnotetext{
${ }^{133}$ Ibidem, p. 385 [134].

134 Ibidem, p. 393 [137-138].

135 Ibidem, p. 395 [138].
} 
cotidiano esquiva-se dessa abertura. Essa esquiva não contraria a ideia de uma abertura; pelo contrário, segundo Heidegger, é uma prova a seu favor. ${ }^{136}$. Se onticamente o Dasein se esquiva de ser aberto num estado de ânimo, ontologicamente isso significa que ele está entregue à "responsabilidade do 'aí",137. Também na esquiva o Dasein é seu "aí", ou seja, está aberto e tem de fazer algo com essa abertura, é responsável por ela. Ser entregue à responsabilidade do "aí", ter de lidar com sua abertura, pela qual os entes e o próprio Dasein se apresentam, significa que o Dasein é levado ao seu ter-deser.

Porém, por que essa entrega à responsabilidade do "aí"? O Dasein é simplesmente lançado a essa responsabilidade. O Dasein é um ente lançado no mundo. Isso é um traço de caráter do ser do Dasein: o ser lançado [Geworfenheit], a facticidade do Dasein. O estado de ânimo aponta para a facticidade, já que leva o Dasein a seu "aí". Podemos dizer, usando o termo dos existencialistas, o estado de ânimo o lança ao seu estar "aí" gratuito e fático. Fático, de facticidade, não é uma fatualidade [Tatsächlichkeit] do "factum brutum de um subsistente, mas um caráter de ser do Dasein" "138. Não é aquilo que é o caso, como um dado, uma qualidade subsistente que calhou de ser. É o próprio ser lançado aí, gratuito. Estar-aí (Dasein) - o termo aponta para o "aí", no qual esse ente já sempre esteve: sua abertura. E o encontrar-se aponta para essa sua facticidade. Por mais emaranhado que o Dasein cotidiano possa estar em suas ocupações, um estado de ânimo pode retirá-lo de lá e jogá-lo ao seu aí. Por que isso de repente? Não se sabe. Não há como, é assim - facticidade. O estado de ânimo "põe o Dasein diante do quê do seu 'aí', como algo que se lhe defronta com o seu caráter de inexorável enigma"139. Portando, o encontrar-se do Dasein leva-nos a ver seu caráter de ser lançado, a facticidade do Dasein. O Dasein já sempre foi lançado "aí” no mundo.

Ao lado do encontrar-se, temos o compreender [Verstehen] como um existenciário fundamental do Dasein e da sua abertura ao mundo. Compreender aqui, no entanto, não consiste no mero conhecer, que é apenas uma forma do compreender, este sendo mais originário, um existenciário. O compreender é uma forma originária com a qual já sempre se está no mundo. Os entes que aparecem ao Dasein, toda significância,

\footnotetext{
${ }^{136}$ Idem [134-135].

${ }^{137}$ Ibidem, p. 387 [135].

${ }^{138}$ Ibidem, p. 387 [135].

${ }^{139}$ Ibidem, p. 389 [136].
} 
toda rede de remissão, em suma, tudo que lhe aparece em um significado do próprio estar em um mundo, desvenda-se pela compreensão. É dessa forma que o utilizável pode lhe aparecer em sua empregabilidade, funcionalidade, em sua rede de remissões, em seu contexto de uso. Também sua relação de preocupação com os outros está ligada ao compreender do Dasein.

Todavia, nesse compreender não se trata de compreender algo, um ente; o compreender é um compreender o ser e o próprio ser do Dasein. Heidegger aponta que às vezes, na nossa fala cotidiana, dizemos "compreender algo", carregando o sentido de "poder enfrentar alguma dificuldade" ou "ser capaz de algo". É um modo que se aproxima mais da noção de compreensão que o filósofo emprega, que é diferente do sentido de compreender como conhecer. Porém, como afirmamos, o compreender, enquanto modo de ser do Dasein, não se refere a algum ente - um compreender algo mas à própria existência do Dasein. "Aquilo que se pode no compreender [Verstehen] ${ }^{140}$ como existenciário não é um quê, mas o ser como existir" "141. Nessa aproximação de compreender como "ser capaz de" etc., vemos sua conexão com a existência. Falamos que o Dasein, enquanto existente, tem de ser a todo o momento seu ser, que está sempre em jogo. O Dasein, na compreensão, compreende a si mesmo em sua existência, em seu poder-ser. "O Dasein é cada vez o que ele pode ser e como ele é sua possibilidade"142. O Dasein, enquanto ser-no-mundo, lida com outros entes: ocupa-se com entes utilizáveis, preocupa-se com outros Dasein; e nisso tudo constitui-se seu poder-ser.

No entanto, sabe-se que essas possibilidades não são ideais, mas possibilidades de um ente que é no mundo. Não são, portanto, possibilidades lógicas, aquilo que poderíamos pensar sem cair em contradição, e sim possibilidades fáticas, de um ser lançado aí ${ }^{143}$. O Dasein, enquanto possibilidade fática lançada, já sempre entrou em certas possibilidades e deixou outras passarem, como costuma acontecer na cotidianidade mediana. A título de exemplo, pensemos nos papeis sociais que são desempenhados em uma sociedade, e que podem ser entendidos como possibilidades definidas da cotidianidade: pode-se ser um professor, um motorista, um médico, um

\footnotetext{
${ }^{140}$ Na tradução de Ser e Tempo que aqui seguimos, Verstehen é traduzido por "entender". Preferimos nos afastar neste ponto dessa tradução e utilizar o termo "compreender".

${ }^{141}$ Ibidem, p. 407 e 409 [143].

${ }^{142}$ Ibidem, p. 409 [143].

${ }^{143}$ Idem [144].
} 
estudante, etc.; com esses papeis, nós nos compreendemos e vemos nossas possibilidades. Quando alguém se compreende enquanto médico, lida com familiaridade com certos entes utilizáveis que estão ao seu redor, e também com os outros (atender um paciente, usar máquinas de raios-X, passar receitas médicas, preparar-se para um curso de especialização, etc.). Os papeis sociais são um exemplo do modo como nós nos compreendemos na cotidianidade; eles nos indicam possibilidades delineadas do que podemos fazer com nosso poder-ser, deixando de fora outras possibilidades.

No entanto, o ser-possível lançado aí que caracteriza o Dasein não significa que ele está fadado a entrar em certas possibilidades e deixar passar outras, como na cotidianidade mediana; e sim que o Dasein também é possibilidade para seu poder-ser mais próprio. O Dasein é "um ser-possível entregue à responsabilidade de si mesmo"144, ou seja, lançado a seu poder-ser, de modo que esse poder-ser mais próprio do Dasein é uma possibilidade sua. Não há, portanto, apenas as possibilidades da cotidianidade mediana, que estreitam as possibilidades e ofuscam o poder-ser mais próprio do Dasein. O compreender é o ser do poder-ser do Dasein ${ }^{145}$. Isso quer dizer que o Dasein compreende a quantas anda seu modo de existir, ele "sabe" sobre o que diz respeito às suas possibilidades, está ciente de seu poder-ser. Como exemplificamos, enquanto médico, posso compreender minhas possibilidades (as coisas a minha volta, as pessoas, meus planos, etc.) de um modo, assim como compreendo de outro modo se me transformo em um monge. O Dasein "sabe" a quantas andam suas possibilidades, compreende a sua existência, o que não é o mesmo que ter um conhecimento correto sobre si mesmo, pois que essa forma originária do compreender, consistente em um existenciário do Dasein, abarca também a má compreensão de si, o autoengano etc. ${ }^{146}$

Algo mais que devemos salientar acerca da compreensão originária do Dasein é que esta tem a estrutura do projeto. Projetar não significa fazer planos, pois que "como Dasein ele sempre já se projetou e se projeta enquanto é". Dito de outro modo, o Dasein já sempre se compreendeu em suas possibilidades, adianta-se de si mesmo em seu poder-ser, noutra palavra, transcende o que é. "Sobre o fundamento do modo de ser que é constituído pelo existenciário do projeto, o Dasein é constantemente 'mais' do que ele

\footnotetext{
144 Idem.

145 Idem

${ }^{146}$ Ibidem, p. 411 [144].
} 
de fato é, se se quisesse e se pudesse tomar seu conteúdo de ser como o conteúdo de um subsistente" ${ }^{, 147}$. Isso quer dizer que o Dasein nunca pode ser definido pelo que está factualmente sendo, pois que ultrapassa aquilo que é; enquanto projeto, o Dasein pode sair do que é em vista de uma possibilidade. O compreender, enquanto projeto, "é o modo de ser do Dasein em que este é as suas possibilidades como possibilidades" ${ }^{148}$, e, assim, nunca é preso ao que está sendo.

O compreender abre o Dasein ao mundo em que os entes se nos apresentam dentro de uma conjuntura, pela qual o ente pode aparecer com alguma serventia. Por exemplo, o lápis que me aparece para fazer anotações, numa conjuntura que envolve outros entes (como um caderno e uma borracha) que me servem para o estudo. Se no compreender tenho essa abertura em que posso lançar mão desse ente (o lápis, no caso), é na interpretação que esse lápis me aparece enquanto lápis; ou melhor, na interpretação vemos o algo enquanto algo ${ }^{149}$. A interpretação tem um papel fundamental na compreensão. Se o Dasein lida com os entes e projeta-se em possibilidades nesse lidar, a interpretação pode dizer ao Dasein que esse ente é para.... Assim, ao interpretarmos, vemos algo enquanto mesa, computador, carro, etc., o que não significa apreendermos esses entes num enunciado que conceitua ou tematiza um ente.

O enunciado é uma forma menos originária, pois que já sempre se compreendeu e interpretou. Os entes que se apresentam já sempre apareceram com um significado nesse ver algo como algo, mesmo que não se saiba seu conceito, que não se tenha definido $^{150}$. Também, não se vê primariamente uma coisa simplesmente como um objeto físico para depois imputar-lhe algum sentido (o que pode parecer quando se sustenta que primeiramente temos uma apreensão perceptiva de alguma coisa, antes de vê-la enquanto algo para...; por exemplo, a cor cinza, a solidez de um computador, etc., antes de vê-lo como computador), já que ele sempre se interpretou, ou seja, apresentouse já em meio a uma conjuntura. A interpretação nunca está isenta de pressupostos; a interpretação já sempre coloca o ente em uma posição prévia em meio a uma

\footnotetext{
${ }^{147}$ Ibidem, p. 413 [145].

148 Idem

149 Ibidem, p. 421 [148].

${ }^{150}$ Ibidem, p. 425 e 426 [150].
} 
conjuntura, já previamente vê as suas possibilidades e também as conceitua previamente $^{151}$.

$\mathrm{O}$ ente me aparece enquanto algo, em meio a sua conjuntura (a mesa me aparece enquanto mesa, no meu escritório, quando a uso para apoiar livros de referências e meu notebook para meus trabalhos); e, se dizemos que esse ente me aparece nessa conjuntura, dizemos que ele tem um sentido ${ }^{152}$. Sentido não é uma caracterização que imputamos aos entes, nem mesmo uma propriedade destes, mas um existenciário do Dasein, assim como a interpretação e a compreensão, dentre tantos outros que apareceram; ou seja, está no modo de ser do Dasein. Não se trata de propriedades de um ente, pois que é pela abertura do Dasein que o ente aparece com algum sentido. O Dasein é abertura: os entes aparecem dentro de uma conjuntura, um algo enquanto algo, sendo para..., com um sentido; tudo isso significa que o Dasein tem uma compreensão do ser desses entes que se lhe apresentam. Em sua relação mais originária, os entes que aparecem ao Dasein veem em um sentido, isto é, aparecem numa rede de remissões, como algo enquanto algo, um ser para..., etc. Ora, se o Dasein é abertura, é o seu aí, pelo qual o ser dos entes é descoberto pelo Dasein, em suma, os entes the aparecem enquanto possibilidades, numa conjuntura, o que quer dizer que tem sentido. No entanto, por vezes notamos algo como "sem sentido"; se, porém, o ente aparece ao Dasein como "desprovido de sentido" é porque o próprio Dasein está "sem sentido". Somente o Dasein pode ser provido ou desprovido de sentido, visto que ele que é a abertura originária, e não as proposições da linguagem. Esse estar "sem sentido" do próprio Dasein quer dizer: o ente foi rejeitado pela não compreensão do Dasein, em vez de ser apropriado no compreender ${ }^{153}$; em suma, não se projetou em alguma possibilidade, não apareceu enquanto algo, está "sem sentido".

Agora podemos entender melhor a antecedência do Dasein no caminho em direção à questão do sentido do ser em geral. Dissemos que, segundo Heidegger, uma das importantes características do Dasein que apoiam a sua antecedência ante outros entes na pergunta pelo ser, está na estrutura compreensiva do Dasein. O Dasein é o ente que tem uma certa compreensão do ser. Ter uma compreensão dos entes em sua volta e

\footnotetext{
${ }^{151}$ Ibidem, p. 427 [150].

152 Ibidem, p. 429 [151].

153 Ibidem, p. 429 [151].
} 
de si mesmo significa ter uma compreensão de ser: o Dasein compreende o ser dos entes e do próprio Dasein. Essa compreensão do ser dos entes significa também que o Dasein tem uma compreensão do ser em geral. Sabemos que esse compreender não se refere a conhecer, mas uma compreensão que se dá em todos os movimentos da existência do Dasein. É daí que se rebate uma possível crítica de circularidade que se poderia dirigir contra o propor-se investigar o sentido do ser a partir de um ente. Afinal, se se analisa o ser de um ente para depois procurar analisar o ser em geral, pressupõe-se o ser já na análise. Ou seja, o autor de Ser e Tempo cairia numa circularidade, na medida em que já se pressupõe o ser para poder investigá-lo ${ }^{154}$.

Heidegger primeiramente afirma que não há aí um problema, visto que se pode determinar um ente em seu ser sem se pressupor um conceito disponível e explícito do sentido do ser; do contrário, não poderia haver nenhum conhecimento ontológico ${ }^{155}$. Em segundo lugar, a própria constituição do Dasein, que tem a compreensão como parte do seu modo de ser, possibilita isso. No compreender, o Dasein tem uma certa compreensão do ser, compreensão prévia, que não quer dizer que tenha um conceito expresso do ser. A compreensão do ser, enquanto existenciário do Dasein, é a base de qualquer conhecimento teórico ou de alguma explicitação que se possa ter sobre o $\operatorname{ser}^{156}$. Em suma, é da própria constituição do Dasein de compreender previamente o ser que se pode extrair alguma explicitação acerca do ser, de modo que o ser está sempre, de certa forma, já pressuposto.

Além da compreensão e do encontrar-se, também o discurso é uma forma de abertura do Dasein ao mundo, e de igual originariedade. O discurso é a articulação da compreensibilidade. Com ele nós interpretamos ou comunicamos nossos estados de ânimo; ele articula a convivência do ser-com. O discurso é também fático: o Dasein já sempre foi lançado num mundo em que as possibilidades discursivas já foram delineadas (com uma gramática, por exemplo). Ademais, o todo de significação, que constitui a mundidade do mundo - visto que o Dasein, enquanto ser-no-mundo, movese numa rede de significados que o orientam em suas possibilidades - é articulado pelo

\footnotetext{
154 Ibidem, p. 47 [7].

${ }^{155}$ Idem [7-8].

156 STEIN, Ernildo. Compreensão e Finitude. Estrutura e movimento da interrogação heideggeriana. Ijuí: Editora Unijuí, 2001, p. 246.
} 
discurso. O discurso é sempre discurso sobre..., ou seja, sempre se referindo a um ente, seja um objeto material, ou um sonho, um desejo, um sentimento, etc.

Não se deve confundir o discurso com a linguagem. O discurso é o fundamento ontológico da linguagem e um existenciário do Dasein ${ }^{157}$. Ele não se resume na expressão oral, como que abrange também enquanto possibilidades o ouvir e o calar $^{158}$. Enquanto a articulação verbal está fundada no discurso, a articulação acústica funda-se no ouvir. Não ouvimos ruídos primeiramente, pois que eles já estão dentro de uma rede de significações. Vem-nos primeiro enquanto buzina do carro, o fogo crepitando, a música no rádio, a voz de um amigo, um violão desafinado. O ouvir é um estar aberto existenciário do Dasein enquanto ser-com, porém também é uma abertura primordial ao próprio Dasein em seu poder-ser mais próprio; ou seja, não só com ele se articula o sercom, a convivência com os outros, mas também é pelo ouvir que o Dasein pode se abrir para seu si-mesmo mais próprio $^{159}$. O calar, por seu turno, é outra dimensão, que concerne ao falar. Ele pode até mesmo dar a entender melhor do que a fala, que não se cala. Não se resume a mudez, o mudo não pode calar-se, ele tem, na verdade, uma tendência ao dizer que não se efetiva. Ao contrário, o calar requer ter algo a dizer ${ }^{160}$. O ouvir, o calar e a escuta são possibilidades do discurso.

Então, o encontrar-se, o discurso e o compreender são formas de abertura originárias de ser-no-mundo. Pela compreensão e pelo encontrar-se, o Dasein vê suas possibilidades a partir do que ele já é. Porém, como se sabe, o Dasein na maior parte das vezes se orienta e cai nas possibilidades dadas na cotidianidade, nas suas ocupações no meio de a-gente. Nesse cair a todo o momento no modo de ser de a-gente, revela-se um modo fundamental do Dasein da cotidianidade: o decair [Verfallen]. Apesar do nome desse existenciário, Heidegger procura retirar dele toda conotação valorativa que se lhe possa atribuir. Vale lembrar que o que o filósofo se propôs a fazer consiste numa analítica existenciária, que nada mais é que, através de uma fenomenologia dos modos de ser do Dasein, uma descrição fenomenológica do ser que não contém conteúdo valorativo. Dessarte, o decair, assim como os outros existenciários apresentados, não

\footnotetext{
${ }^{157}$ HEIDEGGER, Martin. Ser e Tempo. Op. Cit., p. 453 [161].

${ }^{158}$ Ibidem, p. 455 [161].

${ }^{159}$ Ibidem, p. 461 [163]. Como veremos ao falarmos da voz da consciência, que clama o Dasein cotidiano para fora da cotidianidade, em direção a seu Dasein mais próprio.

${ }^{160}$ Ibidem, p. 463 [164].
} 
carregam um valor. Malgrado o termo possa sugerir conotação valorativa (e, no caso, um valor negativo), não se trata de algo como uma "crítica moralizante do Dasein"161 . O decair, que é de caráter ontológico, indica na verdade somente que o "Dasein, de pronto e no mais das vezes, é junto ao mundo da ocupação"162. É um modo de ser em que na maioria das vezes o Dasein se mantém.

O Dasein é absorvido no mundo-com, em que decai na ocupação e se conduz por modos de abertura características do Dasein cotidiano e, portanto, do decair. Dentre as formas de aberturas decaídas temos o falatório e a curiosidade. Enquanto na compreensão nós nos abrimos ao ser, no discurso, pela comunicação, pode-se fazer o ouvinte "participar" do ser que se abriu ${ }^{163}$ (por exemplo, se "compreendo" [Verstehe] um garfo, posso dizer a alguém como utilizá-lo). No falatório, uma forma do discurso, pode-se compreender o que foi dito, mas fica encoberto o ser que foi aberto originariamente na compreensão. Transmite-se a todo o momento o que foi dito, perdendo-se de vista a abertura originária da compreensão. Assim, não se faz distinção entre aquilo que foi meramente dito e repetido no falatório e o que é próprio da abertura. Sem essa distinção, tudo parece ser compreendido, já que o falatório possibilita que se compreenda tudo sem que se aproprie a coisa mesma, visto que tudo pode ser dito e repetido, sem se fazer distinção entre o que é realmente apreendido na abertura ou o que é mera repetição ${ }^{164}$.

A curiosidade, por seu turno, é uma forma de "ver" na cotidianidade. Enquanto no compreender tem-se uma visão originária, uma clareira pela qual o ser dos entes se mostra genuinamente e pela qual o Dasein pode projetar esses entes e a si mesmo em suas possibilidades, na curiosidade esse ver não acontece em vista da apreensão do ser de um ente, mas simplesmente como um ver por ver ${ }^{165}$. Isso que Heidegger nos diz é bastante notável: nós, em nossa vida cotidiana, temos muita curiosidade em saber sobre certos objetos, certos eventos ou sobre pessoas, mas é tipicamente um ver só por ver, um saciar a curiosidade que, depois que se sacia, perde o interesse e parte para outra. $\mathrm{O}$ ver da curiosidade se move em vista da novidade, esta sempre fugaz; e assim, sempre há

\footnotetext{
${ }^{161}$ Ibidem, p. 471[167].

162 Ibidem, p. 493 [175].

163 Ibidem, p. 473 [168].

${ }^{164}$ Ibidem, p. 475 [169].

165 Ibidem, p. 479 [170].
} 
de ir atrás de outra novidade. Dessarte, na curiosidade tem-se uma impermanência junto às coisas, visto que se tem de passar de novidade em novidade, numa incapacidade de permanecer no imediato, no que vem em seu mundo-ambiente. O Dasein fica numa dispersão, visto que, pela curiosidade, tem de estar ciente do que está à volta, sem se apreender propriamente seu ser. Por estar disperso e numa impermanência, o Dasein se encontra em um ser-irrequieto; pois que a curiosidade está "em toda parte e em parte alguma" 166 , já que nunca se alcança ou se sacia, sempre está em busca de algo novo, que nunca repousa em algum ente específico mas vai passando de ente e ente.

As formas de abertura do Dasein cotidiano, como o falatório e a curiosidade, trazem a pretensão do tudo ter sido visto e compreendido, uma certeza de si-mesmo que é, na verdade, própria de a-gente e que o torna indiferente ao compreender e ao encontrar-se. Trazem a ideia de "vida" plena e autêntica, além de uma tranquilidade ao Dasein. Tranquilidade essa que não significa inércia, ao invés, leva-o a mergulhar e afundar-se em atividades. Isso tudo deixa na penumbra o que há realmente a se compreender numa compreensão mais própria, que é seu poder-ser mais próprio, o fardo do Dasein. Assim, damos mais substância ao que foi denominado impropriedade no Dasein: o decair refere-se a esse modo impróprio de ser, que limita as possibilidades do Dasein à cotidianidade mediana.

O decair não sugere uma queda, como no sentido religioso, de sair de uma vida plena e cair num pecado. O Dasein já sempre se encontra no decair; não existe um antes e um depois: o Dasein simplesmente está em meio aos entes, projetando-se em possibilidades dentro de uma cotidianidade mediana. É pelo próprio ser lançado, pela sua facticidade, que ele "decai”. Em suma, o Dasein é desde sempre um ente lançado em seu decair fático; é um ente lançado aí, decaído em sua cotidianidade mediana, na qual no mais das vezes compreende-se a si mesmo e projeta-se em suas possibilidades. O decair, a existência (que envolve a compreensão e, assim, o projeto) e o encontrar-se são as três dimensões fundamentais de ser-no-mundo, os quais Heidegger reúne num único existenciário aglutinador, a saber, o cuidado $[\text { Sorge }]^{167}$. O cuidado é o existenciário que resume a totalidade do Dasein. Todo o modo de lidar com as coisas, com os outros e consigo mesmo; o compreender existenciário, que projeta suas

\footnotetext{
${ }^{166}$ Ibidem, p. 485 [172-173].

${ }^{167}$ Ibidem, p. 511 [182].
} 
possibilidades lançado aí (facticidade), aberto ao mundo por um estado de ânimo, no mais das vezes decaindo em a-gente. Em suma, toda a análise feita até o momento, que Heidegger considera uma análise preparatória (pois que é a análise do Dasein cotidiano, para depois adentrar no Dasein em sua relação essencial com o tempo), todos os modos de ser apresentados aglutinam-se no existenciário fundamental que é o cuidado.

Em vez de simplesmente afirmar o cuidado enquanto existenciário totalizante, Heidegger se pergunta se é possível apreender o Dasein em seu todo. Existe algum modo em que todas essas dimensões do Dasein apresentadas, que parecem esfacelá-lo em vários pedaços sem ligação, possam se apresentar unidas em um todo unitário? A própria noção de cuidado faz pensar que o Dasein nunca pode ser apreendido em sua totalidade; pois, como projeto, ao adiantar-se de si mesmo o Dasein tem sempre algo faltante, que nunca se efetivou, uma incompletude, algo que falta ao poder ser. Por outro lado, na medida em que nada mais lhe falta, o Dasein já deixa de ser "aí". Nada mais lhe falta dado que ele próprio já se consumou, alcançou o seu todo ao chegar a seu fim: a morte. Temos, então, um aparente impasse: o Dasein, enquanto é, está na incompletude; ao se alcançar seu todo, o Dasein não é ${ }^{168}$. Porém, esse aparente impasse se daria numa incapacidade de apreender o Dasein como um todo onticamente. Não sabemos quais são os eventos e decisões de toda a vida de um indivíduo até a sua morte; não sabemos o que ele ainda poderá fazer enquanto viver. Tudo isso é apreender onticamente a existência, saber algo que pode ainda ocorrer na vida de alguém e preencher a sua biografia. A morte, porém, não é algo de subsistente que se acrescentaria ao Dasein, um evento em sua vida. A morte deve, ao contrário, ser vista ontologicamente como constituinte de um modo de ser do Dasein, que Heidegger denomina ser-para-morte.

Como isso é possível? A morte, segundo Heidegger, deve ser tomada como uma possibilidade do Dasein. Não tão-somente uma possibilidade, mas como a possibilidade mais própria, pois que nela "está em jogo para o Dasein pura e simplesmente o seu serno-mundo" ${ }^{169}$. Ela é a possibilidade da impossibilidade do Dasein, ou seja, a de não ser mais um poder-ser, pois que não mais está aí: morreu. A morte é a sua possibilidade mais própria, que o Dasein tem de assumir a cada vez. Contudo, como se chega ao

\footnotetext{
168 Ibidem, p. 655 [236].

${ }^{169}$ Ibidem, p. 691 [250].
} 
conhecimento da morte como projeto? Não se trata de ter um conhecimento expresso ou teórico da morte; aliás, o "Dasein não tem de pronto e no mais das vezes nenhum saber expresso e menos ainda teórico" 170 . É preciso, na verdade, uma forma de abertura mais radical, o pathos da angústia.

O Dasein, como vimos, está sempre em um estado de ânimo, que constitui a sua abertura ao mundo. Porém, o Dasein cotidiano costuma se desviar dessa abertura, atrelando-se em sua ocupação. A angústia o retira do conforto do cotidiano, desfamiliariza-o, e o Dasein, quando está nesse modo de afinação da angústia, não pode escapar da angústia. Esta, ao lado do tédio profundo, é um estado de ânimo fundamental. Isso significa: a angústia é uma abertura, tal como os outros estados de ânimo; porém, por ser fundamental, leva o Dasein a sua existência mais própria, para seu poder-ser fático constantemente acobertado no cotidiano, em que fica preso em ocupações. A angústia, enquanto estado de ânimo fundamental, revela ao Dasein a sua essência: “A angústia diante da morte é a angústia 'diante' do mais próprio, irremetente e insuperável poder-ser". Ela é, pois, ontológica, tem a ver com a constituição mesma do Dasein. Não tem, dessarte, uma causa externa, algo que provoque a angústia, como no caso do medo, que é sempre medo de algo (por exemplo, medo de cachorro ou medo de voar). Pelo contrário, é por simplesmente ser aí no mundo, ou seja, por sua constituição, que o Dasein pode se angustiar. Não há um porquê, apenas se angustia por nada. "O porquê dessa angústia é o ser-no-mundo ele mesmo"171.

O estado de ânimo da angústia está associado a uma relação mais autêntica com a morte, que caracteriza o ser-para-morte em sua autenticidade, o antecipar a morte no projeto. Antecipar a morte não significa efetuá-la; ou seja, em português claro, matar-se. Ela não é algo de que se dispõe como um ente subsistente. Tratar a morte como subsistência está relacionado a uma relação inautêntica com a morte, um ser-para-morte decaído, cotidiano. Cotidianamente, temos certeza sobre a morte. Diz-se: "a-gente também morre uma vez, mas por ora ainda não" ${ }^{, 172}$. Ou seja, todo mundo morre, mas por enquanto não vou morrer. É uma espécie de certeza que a cotidianidade resguarda, a certeza de que todos nós morreremos. Mas a ambiguidade da certeza da morte nos alivia

\footnotetext{
${ }^{170}$ Ibidem, p. 693 [251].

${ }^{171}$ Ibidem, p. 693 [251].

172 Ibidem, p. 703 [255].
} 
do estar lançado na morte, enfraquecendo a morte, encobrindo-a em nosso cotidiano, como se costuma encobrir a essência do Dasein.

No cotidiano, a-gente compreende a morte como um "acontecimento que vem de encontro no mundo-ambiente" 173 . É a única forma que podemos ter certeza no cotidiano acerca da morte, algo dentro do mundo de que a-gente está certo por verificarmos empiricamente que os outros morrem e que assim também um dia morreremos. Essa certeza cotidiana, no entanto, não é de fato um estar certo, pois que adia a morte e não a vê uma possibilidade que pode ocorrer a cada momento. "Dessa maneira a-gente encobre o que a certeza da morte tem de peculiar: que ela é possível a todo instante" ${ }^{174}$. Assim, essa certeza cotidiana acerca da morte vela esse caráter da morte de ser a possibilidade que pode se efetuar a qualquer instante, a possibilidade mais própria do Dasein.

Numa relação autêntica com a morte, esta se vê como a possibilidade mais própria, o que caracteriza a atitude existenciária do antecipar a morte. $\mathrm{O}$ "ser para a possibilidade como ser para a morte deve comportar-se em relação a ela de modo que, nesse ser e para ele, ela se desvende como possibilidade". Esse antecipar a morte é o que Heidegger denomina adiantar-se na possibilidade. Isso não significa, mais uma vez, efetivá-la, porém antecipá-la no projeto existenciário, tomá-la como possibilidade própria, e não vê-la como algo que o atinge de fora. Porém, como se poderia compreender a morte como projeto? A abertura para isso é a angústia. É a angústia que abre para a constante ameaça da morte que surge do próprio "aí” do Dasein. Na angústia “o Dasein se encontra ante o nada da possível impossibilidade de sua existência”. A angústia, que nos põe diante do nada, "se angustia pelo poder-ser do ente assim determinado e abre dessa maneira a possibilidade extrema"175. Ela também, enquanto estado de ânimo singularizante, ao desviar o Dasein do ente em sua totalidade, faz com que o Dasein tenha compreensão de si mesmo enquanto totalidade, a totalidade de seu poder-ser. Se ser-para-morte é adiantar-se em sua possibilidade mais extrema, o que significa também que o Dasein alcança uma relação própria com seu si-próprio,

\footnotetext{
${ }^{173}$ Ibidem, p. 707 [257].

${ }^{174}$ Ibidem, p. 711 [258].

175 Ibidem, p. 729 [265].
} 
assumindo como ser-possível, vê-se que há um vínculo estrutural entre ser-para-morte e $\operatorname{angústia~}^{176}$.

Com a noção de ser-para-morte, mostrou-se uma possibilidade ontológica do Dasein: a possibilidade de o Dasein assumir propriamente suas possibilidades, na medida em que se distancia dos limites estreitos das possibilidades decaídas da cotidianidade, indo em direção ao seu ser-possível que se faz ver na abertura da angústia. No entanto, há ainda de se verificar como o Dasein pode ter testemunho de que possa abrir-se ao poder-ser mais próprio, ou seja, como que da cotidianidade pode o Dasein ser exigido a ir ao seu ser mais próprio ${ }^{177}$. Isso se vê a partir do chamado por Heidegger de voz da consciência [Gewissen]. Perguntamos uma vez pelo "quem" de ser-no-mundo; o si-próprio é o "quem" do Dasein. O Dasein, como foi visto, está amiúde perdido em a-gente e precisa se achar. Para que ele saia das amarras de a-gente e encontre o si-próprio, deve escolher esse si-próprio, realizar uma decisão por seu poder-ser si mesmo, ser resoluto pelo si-mesmo mais próprio. Ou seja, a forma mais própria do Dasein, que condiz com sua essência, não é algo simplesmente entregue ao Dasein, pois que se vê perdido na cotidianidade mediana, que mal compreende seu ser; projeta-se de um modo que limita suas possibilidades as possibilidades já delineadas da cotidianidade.

É preciso que o Dasein se ache para sair de a-gente, porém ele precisa que se the aponte esse seu si-próprio encoberto na cotidianidade. "O Dasein exige a atestação de um poder-ser si-mesmo que ele, segundo a possibilidade, já é cada vez"178. É como se o Dasein, constantemente preso no decair, não visse seu poder-ser mais próprio, e tivesse que ser levado a ele; essa possibilidade precisa, de algum modo, ser atestada ao Dasein. A atestação adviria da voz da consciência. A consciência dá "algo" a compreender ao Dasein, ou seja, ela é abertura. Vimos que a abertura do Dasein constitui-se pelo encontrar-se, o decair, o compreender e o discurso. A consciência se faz ouvir pelo apelo, este que é uma forma do discurso, um apelo que intima o Dasein ao seu ser sipróprio. Mas se a consciência apela, é preciso também querer ouvi-la.

\footnotetext{
176 Ibidem, p. 731 [266].

177 Ibidem, p. 733 [266-267].

${ }^{178}$ Ibidem, p. 737 [268].
} 
O Dasein, enquanto a-gente, deixa de ouvir o seu si-mesmo, ouvindo apenas o direcionamento das possibilidades estreitas de a-gente. "Esse ouvir a-gente deve se romper, isto é, o Dasein deve se dar ele mesmo a possibilidade de um ouvir que o interrompa" ${ }^{179}$. Porém, se o apelo é uma dimensão do discurso, e o discurso é sempre sobre..., do que fala o apelo da consciência? De nada. O apelo não exprime nada, em sentido rigoroso; não há nada em específico que ele diz, nenhuma mensagem a transmitir. Como pode? O apelo da voz da consciência não tem algo determinado a dizer; ou melhor, o apelo "prescinde de toda proferição". Não precisa falar, trazer palavras ao ouvido do Dasein. O apelo não "se põe de modo algum em palavras - no entanto, nada permanece obscuro e indeterminado". O modo pelo qual a voz da consciência fala ao Dasein é pelo silêncio, o calado. "A consciência discorre única e constantemente no modus do calado" ${ }^{180}$. É como se o Dasein fosse chamado para o simesmo mais próprio; não é um pronunciar, não se diz "decida-se pelo seu Dasein mais próprio!"; a referência que esse apelo aponta, o Dasein mais próprio, mostra-se ao Dasein.

Quem, então, diz? Quem apela ao Dasein? O próprio Dasein. O Dasein é ao mesmo tempo interpelado e quem interpela. No entanto, é o Dasein em sua estranheza que interpela a si mesmo. Se o Dasein constantemente decai no conforto das possibilidades da cotidianidade mediana, há uma forma de abertura que o distancia de suas ocupações cotidianas. A angústia é a forma de abertura que the causa essa estranheza, que o distancia das coisas e o abre para seu poder-ser, a estranheza do estar lançado. O estranhamento é o modo fundamental constantemente encoberto de ser-nomundo. A angústia abre ao ser lançado para suas possibilidades. Possibilidades que, porém, não são "soltas no ar”, porque são fáticas: o Dasein está jogado “aí", no mundo, num estado de ânimo, tendo de lidar com os entes. É o próprio Dasein (seu modo de ser: ser-aí) que o chama, noutras palavras, é por sua constituição que o Dasein se angustia e se distancia da cotidianidade decaída.

É o Dasein (seu modo de ser) que interpela a decisão de seu si próprio. Isso significa: o cuidado, o seu existenciário totalizante, apela ao Dasein. O cuidado é o que possibilita a voz da consciência, esta que chama o Dasein ao seu si-próprio. Lembremos

\footnotetext{
${ }^{179}$ Ibidem, p. 745 [271].

${ }^{180}$ Ibidem, p. 751 [273].
} 
que o cuidado é o existenciário aglutinador de ser-no-mundo. Se para se ouvir a voz da consciência é preciso um querer escutar, ou seja, um querer ter consciência, este é compreendido enquanto uma abertura do Dasein. A abertura constitui-se tanto pela compreensão quanto também pelo encontrar-se e pelo discurso. A voz da consciência discorre ao Dasein pelo modo do calar-se, o silêncio que o Dasein é levado a escutar. Isso significa que ela não direciona o Dasein a nenhuma ação delineada, e sim ao seu poder-ser mais próprio. É um silêncio, pois não diz que possibilidade efetivar, que ação tomar, o que fazer: abre-o para suas possibilidades. Quem cala tem algo a dizer, o silêncio é uma forma essencial do discurso, e o que se diz pelo calar-se é o si-mesmo do Dasein $^{181}$.

O Dasein, sempre disperso em suas ocupações cotidianas, é lançado pela voz da consciência a uma culpa originária em que o Dasein sempre está, mas que se oculta no cotidiano. Uma culpa do próprio estar lançado em seu poder-ser, a facticidade da sua existência anterior a qualquer forma de culpa derivada, como a que associamos ao sentido religioso e moral. Dessa forma, a abertura, o "ser aberto do Dasein que há no querer ter consciência é, portanto, constituído pelo encontrar-se na angústia, pelo entender [Verstehen] como projetar-se no ser culpado mais próprio e pelo discurso como ser calado" ${ }^{182}$. É como se houvesse algo faltando na nossa cotidianidade, ou melhor, algo em nossa existência que, de algum modo, sabemos que não se limita às possibilidades de a-gente.

Podemos pensar, já que Heidegger não o esclarece, que essa culpa se relaciona com a própria compreensão que o Dasein tem de sua existência: ele sabe a quantas anda a sua existência e, de algum modo, sente culpa por se afastar do si-próprio. Todavia, isto não seria um conhecimento expresso, mas uma certa ciência existenciária de que a existência é mais que as possibilidades cotidianas e medianas pelas quais nos projetamos. Daqui surge uma resolução. Heidegger fala de um ser-resoluto, de um decidir-se pelo querer. "Esse assinalado modo próprio de ser aberto, atestado no Dasein ele mesmo por sua consciência - o calado projetar-se no encontrar-se da angústia para o ser-culpado mais próprio -, é o que denominamos ser-resoluto" ${ }^{" 183}$. Na decisão, torna-

\footnotetext{
${ }^{181}$ Ibidem, p. 811 [296].

182 Idem.

${ }^{183}$ Ibidem, p. 811 [296-297].
} 
se aberto à angústia, não procurando fugir, como se costuma fazer na cotidianidade. Vimos, portanto, que a voz da consciência, antes de um elemento moral, traz um apelo ao si-próprio do Dasein, as suas possibilidades. A voz da consciência é a forma como o poder-ser do Dasein se desencobre no decair, pois que algo que retira o Dasein da cotidianidade mediana; ao passo que o ser-para-morte, o adiantar-se na morte enquanto possibilidade, é uma possibilidade ontológica do Dasein, que vemos poder "concretizarse" na decisão no chamado da voz da consciência. Como as duas coisas se conjuntam? A chave para isso está na temporalidade [Zeitlichkeit] do Dasein.

Temporalidade e temporalização dos existenciários

Todas as estruturas do Dasein são modos de temporalização da temporalidade. E as estruturas aglutinam-se no cuidado. A temporalidade é o que dá sentido ao cuidado. O que significa isso? Dar sentido é garantir a compreensibilidade de algo, mesmo que não seja explicitado, mas permitir o Dasein ver-se aberto em suas possibilidades. Assim, expor o sentido do cuidado significa responder a questão pelo que possibilita a "totalidade do todo estrutural articulado" do Dasein na unidade de sua "articulação desdobrada" ${ }^{184}$, ver como se dá a unidade dos existenciários articulados no cuidado. Como, então, a temporalidade possibilita isso? Os existenciários são vistos como modos de temporalização da temporalidade. Como isso? E o que significa essa temporalidade? É uma temporalidade originária, que, como veremos, não se resume na compreensão comum de passado, presente e futuro como sucessões de "agoras", um agora que já foi, um atual e outro que ainda virá.

Trata-se nesta seção de ver algumas conexões entre as estruturas elucidadas na analítica existenciária e a temporalidade. Essas estruturas, como vimos, se unificam no existenciário do cuidado e, no ser-para-morte, abrindo-se a possibilidade ontológica da totalidade do Dasein ao antecipar-se em sua possibilidade mais própria. Temos aqui já uma dimensão temporal importante. É na decisão antecipatória da morte que o Dasein pode alcançar seu si-mesmo mais próprio. Todavia, a antecipação é deixar a possibilidade mais própria enquanto possibilidade, é ser para a possibilidade mais própria, o que requer um tipo peculiar de temporalidade. E isso só se faz possível

\footnotetext{
${ }^{184}$ Ibidem, p. 883 [324].
} 
porque o Dasein deixa-se vir a si em sua possibilidade mais própria, ou seja, tem um futuro. Mas futuro não significa algo que vai se efetivar e que ainda não é real, mas refere-se ao fato de o Dasein vir a si em seu poder-ser. O Dasein, enquanto projeto, adianta-se em suas possibilidades, e nisso radica o seu futuro. O futuro é o adiantar-se ou antecipar-se da existência.

Por outro lado, na decisão antecipatória o Dasein vê-se a si mesmo em sua culpa do próprio estar lançado. É por seu próprio modo de ser que o Dasein está em culpa, seu modo de ser ao qual ele desde sempre é lançado na facticidade da existência. O projeto existenciário, seu poder-ser, tem seu chão no estar lançado do Dasein. Assumir o poderser mais próprio leva em consideração o estar lançado. Isso quer dizer: o Dasein, enquanto projeto, sempre já foi (facticidade), de modo que, para se projetar, o Dasein tem de levar em conta o seu passado. E o Dasein só pode ter sido na medida em que é projeto, compreende seu ser em suas possibilidades, sendo assim que o "ser-do-sido", ou seja, o passado, "só surge de certo modo no futuro"185 . O antecipar-se no projeto, o futuro, tem em si mesmo o passado, o já ter sido; mas também o presente. Visto que o antecipar-se abre o Dasein para as possibilidades, abre também para aquelas que estão junto ao Dasein em seu mundo-ambiente: os entes utilizáveis, entes à mão, dos quais dispõe em seu fazer-se cotidiano. São entes que estão já juntos do Dasein em seu mundo-ambiente e o antecipar, enquanto abertura, também abre para eles que se lhe aparecem no presente.

Em suma, presente, passado e futuro estão coligados. Sendo que cada um remetenos às dimensões do cuidado, quais sejam, o decair, a facticidade e a compreensão. Presente, passado e futuro são as ekstases da temporalidade, pontos pelos quais a temporalidade do Dasein se temporaliza, ou seja, temporaliza a sua abertura. O Dasein compreende seu ser, projeta-se em sua possibilidade (futuro), mas está já sempre lançado aí (passado), em meio as suas ocupações (presente). Vemos, então, que é a temporalidade aquilo que unifica o cuidado, sendo que suas três dimensões, decair, facticidade e compreensão, são dimensões temporais que se temporalizam numa unidade de presente, passado e futuro, que se unificam no fazer-se do Dasein, no cuidado. Passado, presente e futuro não são, pois, “divisões" do tempo como

\footnotetext{
${ }^{185}$ Ibidem, p. 887 [326].
} 
habitualmente cremos, mas modos de ser do Dasein, modos originários que possibilitam essas divisões corriqueiras do tempo.

Nesse sentido, o Dasein não é senão temporalidade; o sentido do Dasein é a temporalidade. No entanto, verificar isso apenas pelo cuidado não é suficiente. Malgrado seu caráter aglutinador dos existenciários - ou seja, comportando a totalidade do Dasein - este ente existente deve ser visto em sua multiplicidade; a totalização do Dasein exige essa multiplicidade ${ }^{186}$; os seus variados existenciários não são dissolvidos num todo; eles devem aparecer, são facetas do Dasein, modos temporais pelos quais suas possibilidades se dão. É preciso verificar a temporalidade do cuidado em sua concretude, analisando assim as dimensões desse existenciário totalizante: encontrar-se, compreender, decair e discurso. Dessarte, Heidegger, na segunda seção do seu livro, revê todos os existenciários apresentados na primeira seção agora à luz da temporalidade, a começar pela abertura em geral do Dasein, do compreender, do encontrar-se e do discurso.

O compreender, como já mencionamos, tem por base a ekstase do futuro; ou seja, é no futuro que se dá sua abertura, em que ele se temporaliza. O que é compreender? Projetar-se em suas possibilidades. Porém, isso pode se dar de modo próprio ou impróprio. No modo próprio, o futuro caracteriza-se pelo antecipar. Isso significa que o Dasein, nesse caso, toma a si mesmo como seu poder-ser mais próprio na decisão, que adianta a morte. No compreender impróprio, por seu turno, tem-se a forma imprópria do futuro no aguardar. O Dasein, em seu cotidiano, junto aos entes com que ele se ocupa, não adianta a si mesmo, mas aguarda a si próprio a partir do que se recusa ou se dá daquilo que ele se ocupa ${ }^{187}$. E, assim, porque o Dasein aguarda a si mesmo nas ocupações, ele pode esperar por algo do futuro, aguardar como que por um acontecimento que acontecerá. Enquanto no futuro próprio o Dasein antecipa (na decisão pelo si-mesmo), no impróprio ele espera.

Todavia, é certo que, ainda que o compreender seja primariamente porvindouro, com o caráter do futuro, ele não se temporalizaria se não fosse também cooriginariamente marcado pelo passado e pelo presente. A temporalidade do Dasein não

\footnotetext{
${ }^{186}$ Ibidem, p. 909[334].

${ }^{187}$ Ibidem, p.[337].
} 
aparta presente, passado e futuro como se fossem momentos distintos; eles são unidos e, assim, estão sempre em questão nos modos de ser do Dasein. Como, então, o presente e o passado se dão no compreender? Mais uma vez, trata-se de diferenciar o compreender próprio do impróprio. Na impropriedade o Dasein se faz junto aos entes próximos, do mundo-ambiente, ele mantém-se nas possibilidades estreitas da ocupação, de modo que o presente aí se apresenta como um agora. É um modo impróprio do presente, que se pode denominar presencizar, que significa trazer para um agora. O Dasein presenciza o futuro, já que ele se projeta a partir do que está a sua frente, dos entes de que se ocupa, encobrindo suas possibilidades mais próprias; noutras palavras, o Dasein presenciza na medida em que enxerga suas possibilidades a partir daquilo de que se ocupa. Além disso, nessa forma imprópria do presente, o presencizar, o passado do Dasein, seu ter sido, cai em esquecimento na impropriedade do compreender. O esquecer é um modo do passado do compreender impróprio: esquece-se do estar lançado, deixando-se reter em suas ocupações. Tudo resta presencizado no compreender impróprio, o projetar-se em meio aos entes de que se ocupa, de modo que o Dasein permanece indeciso, ou seja, fechado em seu poder-ser mais próprio. Isso significa que no compreender impróprio o Dasein não se temporaliza pelo futuro, o porvir, mas pelo presente, por aquilo que está presencizado, a sua ocupação.

O compreender, o projetar-se em suas possibilidades, acontece sempre no encontrar-se, como sabemos. Projeta-se, mas projeta-se "aí"; compreende-se sempre em um estado de ânimo, que são formas pelas quais o ser dos entes pode se apresentar. Nisso, contudo, o "aí" pode se fechar ou se abrir; pode-se abrir ao ser mais próprio ou ficar encoberto. "O 'aí' é aberto ou fechado cada vez, cooriginariamente por estado de ânimo" ${ }^{188}$. A temporalidade própria do encontrar-se baseia-se no passado, o ter sido, embora também traga o futuro e o presente, pois que não se desvinculam, são uma unidade. No entanto, se estamos sempre em um estado de ânimo, e este abre o Dasein ao mundo de um modo diferente, a forma como isso se temporaliza também se dá diferente, já que a abertura é uma temporalização.

Para mostrar as formas impróprias e próprias de o passado se temporalizar, Heidegger inicia a análise da temporalidade do encontrar-se pelos estados de ânimo

\footnotetext{
${ }^{188}$ Ibidem, p. 923 [339-340].
} 
consistentes no medo e na angústia. O medo é uma forma imprópria do encontrar-se do Dasein. Isso quer dizer que encobre seu poder-ser fático mais próprio. Medo é sempre medo de algo; medo daquilo que ameaça; no caso, algo do âmbito do que está à mão, utilizável, da subsistência. É um medo de algo que lhe vem, de sorte que se vê o modo impróprio do futuro no aguardar: medo de uma coisa que pode acontecer ao Dasein. $\mathrm{Na}$ conturbação e na aflição próprias ao medo, o Dasein quer apoiar-se, agarrar-se em alguma possibilidade de escape ou salvação daquilo que ameaça. Possibilidade de escape e salvação que se descobre já previamente em seu ver ao redor característico na imersão do mundo cotidiano. Procura qualquer possibilidade dada que lhe aparece, esquecendo-se de seu poder-ser fático.

Contudo, o Dasein não se atém a nenhuma das possibilidades que lhe aparecem de imediato. Todas as possibilidades "possíveis" e "impossíveis" lhe aparecem, de modo que todo o mundo-ambiente se lhe apresenta. O Dasein não se reconhece nesse mundoambiente no medo, porém se agarra a todas as possibilidades imediatas que lhe aparecem, sem, contudo, ater-se a nenhuma delas, indo de possibilidade a possibilidade, de ente a ente. Se, então, o mundo-ambiente se faz presente ao Dasein, que não se reconhece nele, mas busca todas essas possibilidades que aí aparecem, vê-se que ele esquece o seu si mesmo fático - o seu poder-ser ao qual foi lançado. O Dasein permanece em um confuso presencizar tudo o que aparece de imediato, em um "quanto mais próximo melhor" ${ }^{189}$, em vez de vê-lo enquanto possibilidade.

Temporalmente, o medo se anuncia num aguardar aquilo que ameaça e num presencizar tudo aquilo que lhe vem de imediato, o próprio mundo-ambiente; ou seja, aguardar que um evento aconteça e se prender a todos os entes que lhe aparecem no mundo-ambiente. E quanto a angústia? Qual é a sua temporalidade? Sabe-se que ela coloca o Dasein em seu ser lançado pela estranheza do próprio ser-no-mundo. Ela também se caracteriza por uma ameaça, mas esta não vem de algo à mão ou de algum ente subsistente. Aliás, não só a ameaça não vem daí como se perde na angústia qualquer conexão com o mundo-ambiente. Os entes se apresentam fora da conjuntura do mundo-ambiente, de modo que perdem toda significatividade; é como se eles não tivessem mais sentido, não tivessem serventia, um para-quê. Na angústia o Dasein perde

\footnotetext{
${ }^{189}$ Ibidem, p. 929 [341].
} 
de seu mundo-ambiente o ponto de apoio para sua compreensão, seu projetar-se cotidiano, e é lançado ao seu próprio ser-no-mundo, seu poder-ser fático. Angústia aponta para o próprio ser-no-mundo encoberto na ocupação. Os entes ao redor do Dasein se lhe distanciam, pois sua estranheza os afasta; mas ao mesmo tempo eles aparecem como possibilidade.

Como o fenômeno da angústia se dá, então, na temporalidade? Dissemos que o passado, o ter sido, é a base do encontrar-se. No entanto, ele se encobre no medo, pois que aí se esquece do poder-ser fático, presencizando todo e qualquer ente que lhe aparece no mundo-ambiente. $\mathrm{Na}$ angústia, pelo contrário, angustia-se pelo próprio Dasein, seu próprio "aí” no mundo. A angústia derruba-o ao seu ser lançado. O Dasein é um poder ser lançado ao mundo, mas isso fica encoberto na cotidianidade; pois que, em vez de suas possibilidades em sua totalidade se revelarem ao Dasein, ele fica preso a alguns entes, a determinadas possibilidades estreitas. Ao se ver, então, em seu ser lançado, ao qual é direcionado pela estranheza da angústia, o Dasein pode retomá-lo. O Dasein pode retomar temporalmente seu ser lançado ao qual desde sempre esteve, mas que se encobre. A angústia desvela o poder-ser próprio porvindouro (futuro) que pode ser retomado ao "aí" do ser lançado. Porém, o retomar só se dá em uma decisão, a decisão pelo si-próprio. A angústia não o leva à decisão, apenas aponta, em seu modo de afinação da estranheza que o lança ao seu ser-para-morte, que, como vimos, traz a possibilidade mais própria, a morte.

O decair do Dasein, a terceira dimensão do cuidado, tem como ekstase típica o presente. Heidegger parte da análise da curiosidade, um modo do decair. A curiosidade é uma tendência de ser do Dasein na qual ele se ocupa de um poder-ver. Não se restringe aos "olhos", mas no sentido de um amplo deixar vir de encontro "corporalmente" o utilizável e o subsistente. Um deixar vir que se funda no presente, este que é o horizonte ekstático para que o ente possa vir "corporalmente" de encontro ao Dasein ${ }^{190}$. O ente aí não vem de encontro para que o Dasein possa compreendê-lo, mas apenas para poder ver; e isso tem uma unidade ekstática com o futuro e o passado concernentes à curiosidade. A avidez própria da curiosidade faz com que ela não queira aguardar, prendendo-se a uma possibilidade real, uma efetividade, não como uma

\footnotetext{
${ }^{190}$ Ibidem, p. 941 [346].
} 
possibilidade stricto sensu; ou, como coloca Heidegger, a curiosidade "é de todo impropriamente adveniente", porvindoura (futuro), "e isto, por sua vez, de tal forma que não tenha de esperar uma possibilidade, mas que em sua avidez não faz mais do que

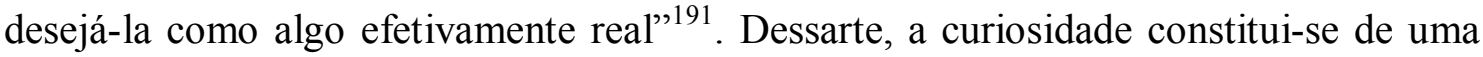
constante presencização na qual se foge do aguardar ao mesmo tempo em que não se demora em um ente: logo que se vê, já se busca outro; ela não quer algo pelo qual se deve esperar, ela quer agora, e quando alcança esse ente, parte para outro, pois, por ser insaciável, a curiosidade tem de passar de ente em ente, de uma novidade a outra, todas presencizadas, possibilidades efetuadas num querer ver agora.

Já podemos notar que a curiosidade, como um modo do decair, tem como temporalidade característica o presencizar. Este é representado pelo decair no arrastamento em ocupações, consistente em presencizações das possibilidades. Quando nos ocupamos com os entes, ocupamo-nos em um agora, lidando com eles enquanto efetividades, não como possibilidades. Quando dissemos antes no texto que o Dasein cai nas possibilidades delineadas da cotidianidade, isso quer dizer que são possibilidades de alguma forma presencizadas: são aquilo que já se sabe que se pode fazer com os entes e que a-gente faz, bloqueando da vista outras possibilidades. Presencizar é uma forma imprópria do presente, é o trazer para um agora, ao passo que sua forma própria nada mais é que o instante da decisão. Que instante é esse? Vimos que a angústia desvela o poder ser próprio do Dasein, o si-próprio porvindouro (futuro), que pode ser retomado ao ser lançado, facticidade (passado). No entanto, isso somente se dá numa decisão que se desvela no instante (presente). É nesse instante que o Dasein pode decidir-se pelo seu ser próprio.

Seguindo a análise temporalizada dos modos de ser do Dasein, ainda há outra forma de abertura não vista, a saber, o discurso. As três dimensões do cuidado - decair, existência (compreensão) e estar lançado (facticidade) - temporalizam-se a partir de suas ekstases próprias - presente, futuro, passado - sem, no entanto, estarem fechadas para as outras ekstases, pois que as envolvem. O discurso envolve essas três dimensões do cuidado: a plena abertura do 'aí'”, que se constitui pelo compreender, pelo encontrarse e pelo decair, "recebe a articulação pelo discurso"192. Ele não está relacionado com a

\footnotetext{
191 Ibidem, p. 943 [347].

192 Ibidem, p. 947 [394].
} 
temporalidade simplesmente por "acontecer no tempo", mas ele mesmo é temporal, no sentido da temporalidade originária do Dasein. Como na maioria das vezes o discurso se dá na linguagem, e com ele se adentra na ocupação ao se discorrer sobre o mundoambiente, ou seja, no decair; é a presencização que possui uma função constitutiva assinalada no discurso.

Temos agora a temporalização das estruturas fundamentais do Dasein. O compreender funda-se primariamente no futuro (no antecipar a possibilidade mais própria ou no aguardar a si mesmo), assim como o encontrar-se e o decair têm respectivamente por base primordial o passado (retomar o estar lançado na decisão ou esquecimento da facticidade atrelando-se ao mundo-ambiente, como no medo) e o presente (o instante da decisão ou o presencizar). Todavia, devemos salientar que a temporalidade se temporaliza totalmente em cada ekstase. Em cada análise dessas três dimensões, apesar da prevalência da ekstase em que elas se fundam, há o envolvimento das outras ekstases: o compreender traz presente o passado no projeto (pois projeto é fático); e a angústia leva o Dasein ao instante da decisão antecipatória. Assim, as três ekstases formam uma totalidade, unem-se num todo estrutural, o qual consiste na temporalidade do cuidado. Não se trata, por conseguinte, de uma sucessão de momentos. A temporalidade se temporaliza em um futuro que presenciza o passado. A ideia de tempo sucessivo enraíza-se na compreensão comum do tempo.

Qual é essa ideia comum do tempo? Heidegger expõe algumas visões sobre o tempo, em uma conferência de 1924, O Conceito de Tempo. Para Aristóteles, o tempo "é aquilo por onde se desenrolam os acontecimentos" "193. É um tempo conectado com a mudança nas coisas. Também se tem em Aristóteles o caráter da mensuração, um tempo que pode ser medido - tempo percorrido, datas, etc. -, o qual podemos associar ao relógio. O que esse instrumento faz? "O relógio mede o tempo, na medida em que a extensão da duração de um acontecimento é comparada por idênticas sequências de estados do relógio e, a partir disso, determinada numericamente em sua quantidade"194. O relógio marca toda vez um agora. Quando olhamos para o relógio vemos, por exemplo, que agora são $23 \mathrm{~h} 30 \mathrm{~min}$; mais tarde, olhamos novamente para o relógio e

\footnotetext{
${ }^{193}$ HEIDEGGER, Martin. O Conceito de Tempo. Trad. Marco Aurélio Werle. em: Cadernos de Tradução. No 2, 1997, p. 11.

194 Ibidem, p. 13.
} 
notamos que agora já são 9 h13min. É um agora que veio depois de outro agora que já foi, um outrora, sendo que mais tarde virá um novo agora, mas ainda não. Dessarte, o tempo comum pode ser entendido como uma sucessão de agoras ${ }^{195}$. Ele está relacionado às nossas ocupações. Medimos o tempo de duração de uma ação, notamos que um acontecimento ocorreu em um tempo determinado (outrora), marcamos uma viagem para daqui a duas semanas, etc.

Contamos, então, com o tempo, este que não é meu, nem teu, nem de ninguém ele é público, "universalmente acessível", todos podem usar um tempo, dar-se tempo. A-gente se ocupa contando com um tempo que não é meu nem de ninguém. Ele está aí, nunca muda, tem sempre o seu ritmo e é igual para todos. É um tempo público "no qual" os entes nos vêm de encontro nas ocupações, os entes utilizáveis e subsistentes, entes do interior do tempo. No entanto, se nos ocupamos dos entes do interior do tempo contando com um tempo público, isso é porque o Dasein já desde sempre foi lançado no decair, no qual ele conta com o tempo nas ocupações ${ }^{196}$. O Dasein, cujo ser é cuidado, já é sempre lançado no decair das ocupações aguardando um poder-ser no mundo. Nesse decair, o Dasein cotidiano conta com o tempo em suas ocupações enquanto uma sucessão de agoras. O que isso vem a dizer? "Agora" nada mais é do que presencizar o tempo ${ }^{197}$. Quando se diz “agora há pouco...”, “de agora em diante...”, entre outras frases que concernem ao tempo na cotidianidade do Dasein, vemos uma articulação discursiva de um presencizar.

Quando se mede um período de tempo, com datas, por exemplo, algo típico da cotidianidade mediana, assume-se uma compreensão na qual uma unidade de medida está contida nessa extensão daquilo que está sendo medido, no caso, o tempo. Assim, veem-se quantas vezes essa unidade de medida se faz vigente na extensão do tempo. $\mathrm{O}$ caráter inalterável da unidade de medida faz com que ela devenha a todo o momento subsistente para todos. Na mensuração do tempo pela datação, ele torna-se acessível ao Dasein como na forma da subsistência. Sendo que na mensuração pela datação primordialmente presenciza-se o que está vigente, essas unidades, com que podemos contar no relógio, são agoras que se tomam como subsistentes ${ }^{198}$.

\footnotetext{
${ }^{195}$ HEIDEGGER, Martin. Ser e Tempo. Op. Cit., p. 1099 [406].

${ }^{196}$ Ibidem, p. 1113 [411-412].

${ }^{197}$ Ibidem, p. 1127 [417].

${ }^{198}$ Idem.
} 
O tempo cotidiano, que se faz público, é, portanto, uma sucessão de uma multiplicidade de "agoras" subsistentes. Como isso se relaciona com a temporalidade originária do Dasein? O Dasein, ao ser aberto à sua possibilidade mais própria pela afinação da angústia, pode decidir-se, no instante (presente) da decisão, pelo seu simesmo mais próprio, antecipando (futuro) sua possibilidade mais própria, a morte, retomando (passado) a sua facticidade, à qual o Dasein já sempre foi lançado, visto que seu poder-ser é sempre "aí". No entanto, o Dasein também já sempre foi lançado em seu decair, no qual se prende às suas ocupações de sua cotidianidade mediana. Nela, temos a compreensão comum do tempo: um tempo público, acessível a todos, e que consiste numa sequência de agoras subsistentes. Esse tempo se apresenta como acessível em nossas ocupações cotidianas.

Porém, de que modo ele se torna acessível? O tempo está relacionado com a própria abertura do mundo, pela qual o Dasein pode descobrir os entes do interior do mundo com que se ocupa, ou seja, pela qual eles aparecem em alguma serventia. $\mathrm{O}$ Dasein, em seu fazer-se cotidiano nas ocupações, conta com o tempo, usando entes utilizáveis como o relógio. Em que consiste o contar? Segue-se atualizando, por exemplo, o ponteiro do relógio de bolso, presencizando-o. Presencizar que nada mais é do que um agora. Quando ajeitamos os ponteiros, nós ajustamos o relógio com o tempo vigente agora. Todavia, o agora sempre muda, torna-se um outrora atrás de outro agora, que será ultrapassado por outro agora que virá, mas agora ainda não. Quando contamos o tempo, contamos com esses agoras, sua sequência. Nesse contar temos uma unidade ekstática de um reter o outrora e aguardar o agora ainda não ${ }^{199}$.

Na compreensão comum do tempo, este se tem como uma sequência de agoras subsistentes que vêm e que passam. Uma sequência ininterrupta e nivelada, que encobre a temporalidade originária do Dasein. Mas é essa temporalidade originária do Dasein, no entanto, o que possibilita aquele tempo comum. O Dasein enquanto cuidado já é sempre lançado no decair (um modo de ser do Dasein), sendo assim que no mais das vezes está imerso em suas ocupações, que requer o tempo público sequencial. Na imersão nas ocupações, o Dasein encobre seu si-mesmo mais próprio, foge da morte e, assim, desvia seu olhar para o fim do ser-no-mundo. Desviar o olhar que é ele mesmo

${ }^{199}$ Ibidem, p. 1135-1137 [421]. 
uma forma de ser para o fim, uma forma de lidar com a morte, o que ekstaticamente é um porvir (futuro), mas um porvir não originário, impróprio. Ora, quando se tem a compreensão mediana da morte, acredita-se que esta é um evento que um dia acontecerá ao Dasein, algo num futuro apartado. Assim, encobre-se o porvir próprio e, por conseguinte, a própria temporalidade originária do $\operatorname{Dasein}^{200}$.

O Dasein cotidiano desvia o olhar de sua finitude, de seu ser para o fim, de modo que a temporalidade imprópria desse Dasein decaído desconhece o futuro próprio, este que adianta a morte enquanto possibilidade, tendo-se assim um Dasein com todas as suas possibilidades a sua frente. Ele se perde na compreensão de a-gente da infinitude do tempo público. Se o poder-ser sempre meu, singular, está na antecipação da morte, no tempo cotidiano, infinito, a-gente nunca pode morrer. $\mathrm{O}$ tempo continua, independentemente de quem nasce. Desse modo, desvia-se o olhar da finitude; na compreensão torta de uma infinitude do tempo público, o Dasein cotidiano foge da morte ao interpretar que "ainda há tempo". Ou seja, o Dasein se orienta num "por agora é só isso, mas ainda há tempo", como que procurando agarrar o tempo que ainda vem, mas que "segue passando".

Ao se dizer cotidianamente que "o tempo passa", quer-se reter o tempo, mas ele não se deixa deter. Aí reside um aguardar pelos instantes; pensa-se "agora só isso, mas depois...", pressupondo-se um tempo infinito, do qual se aguarda os instantes, sem perceber os instantes da decisão que escapam. Não se antecipa o futuro, na decisão no instante, porém se aguarda. Aguarda-se o instante do si-próprio, crê-se que "ainda há tempo" para o que ainda não se deu - sua própria possibilidade. A morte é velada, desvia-se o olhar para ela, não a antecipando enquanto possibilidade (a mais própria), apenas aguardando em uma "ainda não"201 . Em suma, enquanto o Dasein mais próprio pauta-se pelo futuro (o antecipar que retoma a facticidade no instante da decisão), o Dasein cotidiano, por presencizar suas possibilidades, tem o presente como característico.

Tentaremos, agora, resumir o que vimos. O Dasein é cuidado, cujo ser tem como sentido a temporalidade. Ou seja, a temporalidade é condição de possibilidade do

\footnotetext{
${ }^{200}$ Ibidem, p. 1145 [424].

${ }^{201}$ Ibidem, p. 1147 [425].
} 
próprio Dasein e o constitui. Ela o abre as suas possibilidades, o que caracteriza este ente existente que é o Dasein. O cuidado subdivide-se em três dimensões, quais sejam, a existência (compreensão, projeto - futuro), a facticidade (encontrar-se, ser lançado passado) e decair (mundo-ambiente, projetar-se enquanto a-gente - presente). Presente, passado e futuro não são sequências de um tempo que passa, mas fundem-se na unidade ekstática da temporalidade do Dasein. A temporalidade própria do Dasein é sempre encoberta na cotidianidade mediana, pautada pelo tempo público, uma sequência de agoras, em que as possibilidades do Dasein são presencizadas, em vez de vistas como possibilidades. A temporalidade originária, no entanto, pauta-se pelo futuro, na decisão antecipatória do poder-ser fático. Tendo, então, o Dasein a temporalidade enquanto sentido de seu ser, abrem-se as portas para a questão do sentido do ser em geral, que nada mais é senão o tempo.

Pelo que podemos perceber na apresentação da ontologia fundamental, Heidegger busca apontar para o si-próprio do Dasein, constantemente acobertado na cotidianidade. É uma orientação para a existência autêntica, ou seja, que leva em consideração o ser mais próprio do Dasein. É uma orientação, no entanto, que discorre pela voz do silêncio, visto que não há expressamente um caminho delineado que se deva seguir. Ademais, se a existência autêntica se relaciona com o ser-possível, vemos então que não se pauta por nada na efetividade, pois que se tem de deixar abertas as possibilidades enquanto possibilidades, não efetivá-las, para fazer jus ao poder-ser próprio do Dasein. A existência, enquanto abertura, não se prende a nada - ela é fática, já lançada no decair (em que se pauta pelas possibilidades efetivas de a-gente), porém é também transcendência, pois que o Dasein sempre ultrapassa a si mesmo. A voz da consciência, que discorre pelo silêncio da estranheza da angústia, clama o Dasein para fora da cotidianidade. Para onde? Ao seu próprio ser-no-mundo, seu ser-possível fático, o que, como possibilidades puras, embora "aí", no mundo, não têm massa, são vazias na medida em que permanecem enquanto possibilidades. No próximo capítulo veremos porque e como estas possibilidades não são nem poderiam ser possibilidades éticas em sentido tradicional. 


\section{CAPÍTULO 3.}

\section{Elementos para uma metaética fenomenológico-existenciária heideggeriana.}

\subsection{Rejeição existenciária das éticas tradicionais em geral.}

Ontologia fenomenológica, Dasein e temporalidade foram as três articulações heideggerianas apresentadas no capítulo anterior. Mostraremos agora como elas rejeitam a dimensão da moralidade presente nas teorias éticas examinadas no primeiro capítulo, e como o assumir tais elementos existenciários impossibilita adotar o ponto de vista ético tradicional.

O presente capítulo estará dividido em três seções: na primeira, veremos como esses elementos descartam de plano as articulações éticas tradicionais em geral, sem considerar teorias éticas específicas. Apenas para reforçar a argumentação, na segunda seção se mostrarão rejeições existenciárias de teorias éticas específicas (virtudes, contratualistas, deontológicas, etc). Por fim, na última seção, tentar-se-á resumir as principais teses metaéticas heideggerianas que possibilitam essa rejeição da ética tradicional em geral e de teorias éticas em particular.

Para iniciar este estudo, pode-se lembrar que a motivação básica que impulsa todo o pensamento de Heidegger é a questão pelo sentido do ser, questão que, segundo ele, foi trivializada ao longo da história da metafísica europeia, tornada supérflua e, por fim, esquecida. Heidegger procura descontruir a história dessa metafísica de maneira que se mostrem as "experiências originárias" das quais surgiram as diversas determinações do ser, que foram se tornando evidentes e triviais. Precisamente, a ética tradicional estaria, segundo Heidegger, internamente ligada à metafísica, de modo que também a ética tradicional faria parte do esquecimento da questão do ser e da sua trivialização. A ética tradicional pressupõe ou mesmo utiliza certas determinações do ser e as cristaliza em direções fixas da existência. Noções como "pessoa" e "sujeito" são algumas dessas determinações de ser que se tornaram evidentes e nas quais a ética tradicional se baseia. Nas teorias éticas apresentadas, encontramos concepções acerca do ser humano e das coisas, de suas propriedades e sua essência, vistas como condições para atingir os objetivos propostos por cada teoria ética. Essas propriedades do humano, fundamentais para as teorias éticas tradicionais, são tomadas - em termos da filosofia da existência de 
Heidegger - sempre no modo da mera subsistência, que é apenas uma forma do ente se apresentar.

Não é própria da ética tradicional apenas a busca pela elucidação do sentido do ser, mas procura, fundamentalmente, o valor. A ética tradicional impõe valores aos entes e ao próprio Dasein, julga seus modos de projetar-se, em suma, examina valorativamente os modos ônticos pelos quais o Dasein faz seu ser. A ética tradicional não se atém, pois, ao ser, este fica atrás do valor. Ao direcionar seu olhar ao valor, o ser fica encoberto nas éticas tradicionais. O projeto heideggeriano em Ser e Tempo, por seu turno, não foca a questão do valor, um patamar que ele consideraria superficial e deturpador. Trata-se apenas de descrever modos de ser. E isso se vê no próprio método que o filósofo lança mão: a fenomenologia, entendida como um método eminentemente descritivo, não valorativo. A fenomenologia, na apropriação muito peculiar de Heidegger, é aquele método que procura apenas "fazer ver" a partir daquilo que "se mostra tal como se mostra"; no caso de Heidegger, o foco da fenomenologia é o ser; é este que tem de ser descrito fenomenologicamente. "As coisas mesmas", às quais a fenomenologia heideggeriana quer chegar, não incluem valores, mas apenas modos de ser. Nesse sentido, valores não aparecem. O método fenomenológico de Heidegger não capta valores. Não que eles estejam "encobertos", mas que eles, pura e simplesmente, não se mostram, pois o encobrimento ainda faria parte do mostrar-se originário de um fenômeno. Os valores, por seu turno, não são fenômenos para essa fenomenologia e, portanto, não se mostram sob o olhar fenomenológico do filósofo de Ser e Tempo. É o ser o fenômeno primordial a ser descrito pelo método fenomenológico nessa obra, tal como ele aparece e se oculta.

Então, a primeira articulação da análise heideggeriana - a ontologia fenomenológica - já rejeita quase que espontaneamente não apenas os valores éticos, mas os valores em geral (os valores estéticos, por exemplo, teriam igual sorte). Os valores simplesmente não aparecem nessa fenomenologia; eles não são fenômenos. Vejamos o que acontece com a segunda articulação examinada no capítulo anterior. $\mathrm{Na}$ fenomenologia heideggeriana parte-se da análise de um ente exemplar, do peculiar modo de ser desse ente no qual o ser mesmo está em questão, para investigar o sentido do ser em geral; esse ente exemplar, como sabemos, é o Dasein. O Dasein é o modo de ser próprio do humano, que aponta para a relação peculiar que este tem com o ser. $\mathrm{O}$ 
Dasein é o ente que tem de ser, pois que não é determinado, não tem um quid, mas consiste em pura possibilidade de ser. Ele não é caracterizado por propriedades, mas por um modo de ser, pela existência, que, em vez de designar existentia, simples presença, subsistência, significa ek-sistere, ou seja, abertura e transcendência. Mas, precisamente, as éticas que apresentamos trabalham com um ser humano constituído e definido por certas propriedades; essas éticas pressupõem um humano com características tais como a racionalidade, o sentido das coisas (da justiça, do bem), com diversos tipos de alma, com inclinações, etc., não vistas como possibilidades mas como determinações subsistentes e constantes do humano, que lhe fornecem uma espécie de massa sólida, aquela necessária para sustentar uma perspectiva ética qualquer, em sentido tradicional. As éticas tradicionais não veem o humano enquanto ser-possível, e sim como um ente caracterizado por certas e determinadas propriedades, que devem ser trabalhadas ou evitadas para atingir um comportamento ético. Nessas éticas, almeja-se evitar certas atitudes, desligar-se de certas inclinações, pautar-se pela racionalidade ou guiar-se por sentimentos morais, em vista da exigência de ser virtuoso, ou de agir pelo dever, ou de conviver pacificamente em uma sociedade ou de saber prever as melhores consequências das ações em prol da felicidade geral. Todos esses objetivos pressupõem e exigem um ser humano definível por propriedades estáveis.

No entanto, se o Dasein é um ente de puras possibilidades, um modo de ser que é abertura, projeto e transcendência, pareceria razoável pensar que as éticas tradicionais elas mesmas poderiam considerar-se, desde a perspectiva da análise existenciária, como máximo, apenas como possibilidades da existência pelas quais o Dasein poderia decidir se guiar, mas nunca como exigências imperativas e absolutas. De todos os comportamentos possíveis que se podem adotar, o Dasein poderia decidir pautar-se pelas exigências morais dessas éticas. Em outras palavras, a ética tradicional poderia devir um projeto de ser do Dasein. Porém, o modo de ser da existência significa também transcendência: o Dasein é um modo de ser que constantemente ultrapassa a si mesmo, está além do que decide ser. O ter de ser do Dasein é aberto, ele nunca se prende à efetividade como que a transcende, projetando seu ser (seja de maneira própria ou não). Se o Dasein tomasse a decisão de pautar sua conduta pelas exigências morais, esta seria sempre uma possibilidade transcendida pelo Dasein em vista de outras possibilidades. Todavia, isto pareceria ser muito menos que o que a ética tradicional exige. O que é que essa ética visa? Que ela se veja como mera possibilidade do humano, 
apenas como um projeto de existência entre outros que pode ser transcendido? Não. A ética não se formula, ao longo da história do pensamento europeu (visto em esboço no capítulo 1), apenas como mera possibilidade e sim como uma exigência, ou, no mínimo, como uma recomendação, seja para uma plena realização da natureza do humano, seja porque acredita estar formulando o correto modo efetivo de ser. A ética tradicional se vê a si mesma como um modo de ser efetivo e não meramente possível, modo de ser que se destaca qualitativamente de outros por orientarem o humano para um fim bom, para ações ou atividades que sejam consideradas como as mais corretas ou plenas, etc.

O Dasein não pode incorporar na existência uma exigência incondicional e absoluta que aponte ao modo de ser efetivo exigido pela ética tradicional. Ser aberto, o que constitui o caráter da existência, a "essência" do Dasein, não o leva a alguma direção delineada, mas a seu poder-ser. Nesse sentido, a ética em sentido tradicional não teria qualquer prioridade com relação às outras possibilidades da existência. Porém, por outro lado, sabe-se que o Dasein, enquanto existente, não é um poder-ser puro e solto, totalmente arbitrário, pois que já sempre está faticamente lançado em seu decair, pautando-se pelas possibilidades que perfazem a cotidianidade mediana. Essas possibilidades estão delineadas ontológico-existenciariamente, não eticamente em sentido tradicional. O decair, como vimos, é uma das dimensões fundamentais do Dasein, o que significa que esse ente humano no mais das vezes compreende-se a si mesmo e os outros entes, projeta suas possibilidades seguindo as orientações de seu mundo-ambiente, as possibilidades que lhe estão mais próximas. Mas, apesar do possível caráter negativo que o termo "decair" parece carregar, Heidegger descarta qualquer interpretação valorativa desse termo. Trata-se de um modo de ser do Dasein, não indica uma valoração. Não é, por exemplo, um castigo por algo que o humano fez no passado, pois que faticamente ele já está desde sempre lançado nesse seu decair.

O decair é, pois, constituição ontológica. O si-mesmo no decair é o si-mesmo de a-gente. Isso vem a dizer que quando o Dasein trabalha como se trabalha, pensa como se pensa, passeia como se passeia, ama como se ama, despreza como se despreza, atende como se atende, em suma, projeta-se como se projeta, e assim compreende seu ser e suas possibilidades enquanto a-gente, afasta-se da singularidade do seu si-próprio autêntico. O decair como uma dimensão estrutural do Dasein aponta que ele na maioria das vezes está num modo inautêntico de ser, mas não comete com isso qualquer falta 
moral. Todavia, dentre as possibilidades efetivas da cotidianidade do Dasein podemos encontrar a ética tradicional. O modo de ser ético, em sentido tradicional, é consistente com o Dasein decaído, com o si-mesmo de a-gente. A ética tradicional também pode massificar o Dasein, dado que traz preceitos, finalidades, direções que todos deveriam tomar. Para ser ético, ao menos em um sentido tradicional, deve-se agir assim, evitar tal coisa, assim por diante: procurar seguir as leis racionais universais, ter um modo de vida que conduza para a realização da natureza humana, promover a felicidade da maioria etc.. Todas estas são noções massificantes, que encobrem o si-mesmo do Dasein orientando-o para a um caminho padrão, para possibilidades de a-gente. Somos corretos como as pessoas são corretas, tentamos ser éticos como, em geral, tenta-se ser ético, etc..

Quando, por exemplo, ensinamos às crianças alguns valores, chega um momento em que simplesmente temos de afirmar que "isso é assim", que "tem de fazer desse jeito", que "isso não pode", "é errado", "é feio" e acabou. Isso pode apontar para o que dogmaticamente deveria ser aceito como ético numa comunidade; não mais se pergunta por esses valores, simplesmente são aceitos na cotidianidade, em sintonia com o modo do decair. Pode-se objetar que, em casos de indivíduos adultos, é possível argumentar e persuadir sobre em que consiste uma boa ação em sentido ético, perdendo-se o caráter inquestionável, deixando de ser algo com que simplesmente se age em sintonia, levados pelo modo de se compreender de a-gente. Mesmo assim, o ponto é que a ética tradicional determina certas possibilidades determinadas do Dasein que podem ser entendidas como regras gerais, como exigências ou recomendações acerca de como se deve comportar - o que é estruturalmente o mesmo para adultos e crianças. Mas o "por quê?" que insiste em ressoar nas vozes das crianças ao receberem as orientações dos adultos aponta talvez para a estreiteza disso: os valores que permeiam as recomendações, as ordens, etc. destacam certas possibilidades efetivas do Dasein e encobrem outras. O si-mesmo próprio do Dasein é encoberto em prol do si-mesmo de agente, agora como um a-gente ético em sentido tradicional, com valores, normas e fins generalizantes.

Vemos que a ética tradicional pode ser parte do decair. Isso também nos mostra melhor por que Heidegger retira qualquer caráter valorativo da dimensão existenciária do Dasein. Também a ética tradicional trata da decadência; mas esse decair ético, essas 
decadências morais são formas ônticas e valorativas que não se mostram na fenomenologia do Dasein, ou o fazem apenas como formas existenciais derivadas, não originárias. Trata-se de uma decadência moral que concerne a vicissitudes ônticas; quedas pecaminosas, ações degradantes (como crueldades, extermínios), pessoas que "caem em decadência" (por cometerem crimes contra a moral, etc.) são todas formas de decadência moral, mas não têm conexão intrínseca com o decair ontológicoexistenciário a não ser como formas derivadas; mas do decair ontológico-existenciário também poderiam surgir experiências de grande elevação moral. As decadências morais podem ser formas ônticas do decair, entre outras formas que podem considerar-se morais ou mesmo amorais.

O decair da analítica existenciária representa simplesmente que o Dasein, na maior parte das vezes, compreende-se a si mesmo na cotidianidade mediana, encobrindo seu si-mesmo mais próprio e projetando-se no modo de ser de a-gente. Não se trata de nenhuma degradação de valor. O Dasein não perde valor por decair. Pois o decair pode abranger tanto comportamentos ônticos condenáveis como louváveis ética ou valorativamente. Por exemplo, existem formas na cotidianidade mediana de trivialização da violência; porém, ser simpático e atencioso para com os outros pode também ser uma forma do decair, do ser-com do Dasein na cotidianidade, um hábito que se faz porque se faz; ou seja, ambos podem ser partes do modo de ser de a-gente. Todavia, os comportamentos morais, imorais ou amorais são, todos eles, dimensões do decair, que consiste simplesmente em uma dimensão existenciária do Dasein que concerne a seu modo de ser, e não a qualquer tipo de valor.

Se, no entanto, admite-se que a atitude ética em sentido tradicional faz parte do Dasein decaído e que Heidegger quer trazer à luz a existência autêntica que se desprende das estreitezas da cotidianidade mediana no decair, pode-se ainda afirmar que a ética tradicional é uma possibilidade do Dasein, embora imprópria existenciariamente, por encobrir o si-mesmo do Dasein; seria uma possibilidade à qual o Dasein pode procurar seguir por uma exigência ôntica. Sabemos, contudo, que na existência autêntica não se trata somente de uma forma de assumir-se do Dasein. Ela exige do Dasein esse assumir-se a si mesmo, exigência que se ouve desde a voz da consciência. Mais uma vez, Heidegger tenta afastar qualquer interpretação dessa voz que a desloque da pura ontologia levando-a para alguma esfera de valor. A voz da consciência não é 
uma consciência moral; é antes um chamado ao poder-ser mais próprio do Dasein. A culpa que recai ao Dasein, não é por um pecado, nem por um crime moral, mas por ter se afastado de si-mesmo, da propriedade da existência. Vemos que isso está bastante apartado do âmbito moral, e pode mesmo retirá-lo da moralidade, se esta estiver dentro da cotidianidade mediana, aconselhando seguir normas, valores, preceitos generalizantes. A voz da consciência fala ao Dasein pelo silêncio, pois que não há qualquer caminho delineado, como há nas éticas tradicionais. Estar aberto às possibilidades emparelha-as todas, retira o relevo que as possibilidades éticas habitualmente pretendem ter na cotidianidade, trazendo outras à decisão do Dasein.

Mas que força é essa que a voz da consciência tem e que, num tom silencioso, retira o Dasein da tranquilidade da cotidianidade mediana? A voz da consciência fala na tonalidade da angústia. A angústia é um estado de ânimo fundamental, que, assim como o tédio profundo, aponta o Dasein para seu próprio estar aí, seu poder-ser fático. Outros estados de ânimos, não fundamentais, podem encobrir e desvelar os entes em um modo que fica perdido o ser si-mesmo do Dasein. O medo, por exemplo, faz com que o Dasein se perca no mundo-ambiente, atrelando-se a todo ente que lhe vem à frente, ao passo que a angústia o retira do mundo-ambiente e o leva ao próprio ser-no-mundo enquanto tal. A angústia que estranha o Dasein é um estado de ânimo fundamental no horizonte da autenticidade da existência, mas pode aparecer como fortemente negativa para a perspectiva da ética tradicional. Estranhar-se do mundo ao redor, dos outros e de si mesmo pode atrapalhar as tentativas do ser humano de ser ético, eticamente correto, em sentido tradicional. Como agir eticamente na agonia da angústia, que estranha o Dasein de si mesmo e dos entes ao redor em sua totalidade? Um indivíduo virtuoso, um cidadão que cumpre o contrato, um sujeito experiente que calcula bem as consequências de seus atos ou uma pessoa livre que estipula máximas morais para si mesmo, ao verem-se na estranheza da tonalidade afetiva da angústia, podem estranhar-se de si mesmos, perderem-se de suas virtudes, contratos, cálculos ou autodeterminação, lançando-se no seu puro ser-aí no mundo.

A angústia não parece, pois, dialogar com a ética tradicional. O medo, por seu turno, embora não necessariamente ligado ao ético, pode, sim, sujeitar os indivíduos a uma certa ética, como vimos ser o caso na constituição do Estado na teoria contratualista de Hobbes: medo de cometer um crime moral, medo de um mal maior que 
o impele à segurança do contrato, medo de prejudicar os outros e que faz com que alguém seja mais prudente, etc.; em suma, o medo, um estado de ânimo do Dasein inautêntico, distanciado de seu poder-ser, pode estar mais de acordo com a exigência ética tradicional do que a angústia, que deixa radicalmente desprotegido e lançado. Certamente, o medo nem sempre pode ser visto em diálogo com a ética tradicional; uma ação correta realizada simplesmente por medo pode ser considerada, numa ética deontológica kantiana, apenas como uma ação conforme ao dever; e na ética aristotélica, o medo pode ser visto como um vício que paralisa o indivíduo. Afirmamos que o medo pode ou não alinhar-se com a ética. Como o Dasein está sempre em um estado de ânimo, é certo também que na ética a abertura do encontrar-se em estados de ânimos está atuante. Todavia, um humor fundamental como a angústia, que enfraquece o vínculo com os outros e com as coisas, tende a debilitar também o virtuoso, o autolegislador, etc., deixando apenas o Dasein diante das suas possibilidades fáticas, não forçosamente éticas em sentido tradicional.

Os estados de ânimos, sob cuja afinação o Dasein sempre se encontra, apontam para a facticidade do Dasein. Este é um poder-ser que se compreende e projeta seu ser, mas sempre numa facticidade. O Dasein está “aí". O estado de ânimo afina o Dasein de modo que ele se encontra assim ou assado, os entes se lhe desvelam de determinada forma. Por quê? Não se sabe - é uma facticidade. A existência do Dasein é fática. É uma gratuidade que, talvez, possa ter ressonâncias na ética. Por quê? Porque o Dasein, enquanto lançado faticamente em um mundo, não tem nenhuma finalidade, a sua existência fatual é absurda e gratuita; tudo o contrário do que pressupõem uma boa parte das teorias éticas, especialmente as teleológicas, como apresentamos, que aceitam um fim último para o humano. Mas a facticidade e o caráter gratuito da existência, em que o Dasein já de sempre se encontra, lhe retira toda finalidade; nada indica para quê o Dasein está aí no mundo nem para onde deve ir. Ele simplesmente está aí, na cotidianidade e a facticidade do decair. Compreende-se a si mesmo, projeta seu ser em um mundo em que está lançado, mas o Dasein não tem fim, é um vazio do poder-ser fático, sem rumo. Os valores com que lida na cotidianidade se sustentam em quê? A facticidade faz com que eles percam toda dignidade metafísica intrinsecamente sustentadora; o próprio Dasein perde a sua dignidade. Isso significa que é indigno? Não, apenas que dignidade ou indignidade, ou melhor, qualquer tipo de valor do Dasein é 
atribuído onticamente e não tem um fundamento que o sustente; é o abismo do ser-aí sem sustentação.

A facticidade do Dasein indica um ser lançado no mundo. O Dasein está "aí" no mundo. O Dasein, enquanto ser-no-mundo, mundaniza, familiariza, habita, lida com os entes que lhe vem de encontro. Portanto, o mundo existenciário não é um conjunto de humanos e de coisas dados, com os quais nos relacionamos e dos quais podemos dispor. No entanto, as éticas tradicionais precisam de um mundo que seja um lugar, um espaço objetivo de ação. Nesse mundo há humanos e coisas com propriedades com as que se conta, com as quais se pode trabalhar. Esse mundo é composto, por exemplo, de perigos aos quais os humanos em estado natural, como seres egoístas, podem sucumbir; há um mundo sensível moldado pela causalidade da natureza, e um mundo espiritual ou inteligível onde acontecem os atos livres humanos e se ponderam em seu valor; há ali a força da fortuna com que o sábio virtuoso tem de lidar; etc.. Todas estas são concepções de mundo como sendo um local com certas propriedades que enfrentam os humanos, que facilitam ou ameaçam, e com os quais as éticas tradicionais têm de lidar; completamente diferente do mundo do mundanizar existenciário, relacionado ao Dasein por uma rede de significações nas quais o Dasein se projeta a si mesmo e se movimenta com familiaridade.

Ser-no-mundo, na analítica existenciária, é também movimentar-se em um mundo-com; o Dasein é ser-aí-com, não se encontra apenas com entes com que se ocupa, mas também com outros entes que têm o modo de ser do Dasein, e com os quais se preocupa. O termo "preocupação" poderia sugerir, a princípio, uma referência a formas de lidar com os outros estudadas pela ética, no sentido, por exemplo, de estar atento ao outro, de estar aflito por ele, ou mesmo ser atencioso com os outros. Porém, "preocupação" na analítica existenciária aponta para uma estrutura do Dasein que engloba todas essas formas ônticas de se lidar com os outros. No preocupar-se existenciário encontramos o carinho, a consideração, o respeito, mas também $\mathrm{o}$ descuido, o menosprezo, a crueldade. As específicas formas éticas de se lidar com os outros são apenas determinadas formas da preocupação ontológica, que, enquanto estrutura do Dasein, é aberta a outras determinações. Tanto nos "preocupamos" existenciariamente com os outros quando os protegemos como quando os agredimos. A ética tradicional limitaria o ser-com existenciário apenas na direção da proteção, 
excluindo e condenando outras formas da preocupação ontológica. Como estrutura ontológica, ela inclui todas as formas de estar com os outros, assim como, segundo Heidegger explica, a total solidão é também um modo do ser-com. Dessarte, o convívio pacífico em uma sociedade, a cidadania, os conflitos entre humanos ou a reclusão são todos modos do ser-com e da preocupação; nenhum deles tem precedência em relação ao outro, são todos possibilidades do Dasein num mundo-com.

Ser-no-mundo-com indica também compartilhar com os outros da rede de remissões, a significância do mundo, que constitui a mundidade. O discurso é uma dimensão fundamental do Dasein que se refere a essa rede de remissões e a ligação com o ser-com. Ele é uma forma de abertura do Dasein ao mundo, e articula as outras dimensões do cuidado, a compreensão, o encontrar-se e o decair. O discurso não se resume na linguagem falada, pois que é uma estrutura mais originária, sendo também inclusos o silêncio e a escuta como dimensões da fala. Uma grande parte da ética, pelo contrário, precisa da fala explícita, ou de uma análise dos termos de proposições morais. Difícil articular silêncio e escuta com exigências éticas tradicionais. A ética tradicional usa a linguagem no modo da comunicação, visto que ela se faz presente, por exemplo, na convivência; a ética tradicional precisa de algum tipo de diálogo para o acordo entre grupos. São articulações ônticas do discurso. Todavia, quando o Dasein se vê lançado ao seu ser aí mais próprio, é pelo silêncio da angústia que a voz da consciência apela ao Dasein. O Dasein deve estar disposto à escuta da voz da consciência para não fugir de volta para a cotidianidade do falatório. O diálogo na ética tradicional é uma forma ôntica do discurso, derivada, não originária. O chamado da voz da consciência traz o silêncio singularizante da angústia que apela ao Dasein que deve escutar, retirando-o de qualquer comunidade, mesmo de comunidades éticas. A decisão é um ato singular, solitário, enquanto a ética tradicional parece forçosamente comunitária e dialógica.

O silêncio singularizante da angústia traz o tom do ser-para-morte autêntico. Com este tema, entramos finalmente na terceira articulação vista no capítulo anterior: a temporalidade. A morte é também, certamente, um tema tradicional da ética; mas tratase sempre de uma morte que "advém" à vida, de uma morte ôntica que acontece no interior do mundo, no tempo do mundo. Na ética tradicional procuram-se acordos para evitar conflitos e evitar mortes; mas também se reflete sobre a experiência moral do morrer e do "preparar-se para a morte". Procura-se uma vida virtuosa pela qual se 
adquire uma sabedoria para lidar bem com as mazelas da vida, o que inclui um saber lidar com a morte; a ética tradicional foca atos humanos em que a vida é sacrificada (para salvar alguém); tenta-se definir o bem viver, sem um desgastar-se "pensando na morte"; acontecem debates bioéticos sobre aborto, suicídio e eutanásia. Todas estas são formas de lidar com a morte que a colocam como um evento que "acontece" na vida, como um acontecimento ôntico.

Longe disso, na analítica existenciária, o ser-para-a-morte antecipa a morte como possibilidade mais própria do Dasein. A morte adquire uma dimensão ontológica. A morte como fato adventício é um encobrimento da morte enquanto possibilidade mais própria, porque se vê como algo que vai acontecer na vida humana como um evento alheio e impessoal (afinal, "todo mundo morre", como se repete no falatório). A morte, na analítica existenciária, deve ser antecipada no projeto. A angústia, enquanto angústia diante da morte, abre o Dasein para sua morte singular e intransferível, dentro de uma escolha de si-mesmo. A morte é vinculada com a totalidade da existência. A totalidade do Dasein consiste em um poder-ser, em possibilidades que mantém a morte como horizonte. Não se trata, assim, da mera efetividade da morte ôntica, esquecida cotidianamente em sua "certeza". Mas essa totalidade do Dasein tampouco tem a ver com alguma "totalidade moral", tal como a "integridade da pessoa", uma "vida plena", etc. A totalidade moral alude a formas ônticas de lidar com a existência, tais como tomar determinadas atitudes, realizar plenamente determinadas propriedades subsistentes que se supõem no humano, etc.. A totalidade do Dasein, por sua vez, não se vincula com nenhuma totalidade efetiva como as que a ética tradicional procura, mas na apreensão do Dasein em seu poder-ser total. O existenciário totalizante do Dasein consiste no cuidado, que, como vimos, aglutina todos os existenciários. Assim, o Dasein, mesmo em sua totalidade, nunca se preenche, é sempre faltante, enquanto nas éticas tradicionais é prometida ao humano uma integridade moral que efetivamente se atinge a partir de práticas.

Em vez de plenitude, o Dasein é finitude. Adiantar-se em seu ser-para-morte é tomar-se e aceitar-se enquanto finito, na finitude própria da temporalidade do Dasein. Sua temporalidade originária, como vimos, é a confluência entre passado (facticidade), futuro (projeto) e presente (instante) unindo-se na decisão antecipatória. Todavia, o Dasein já sempre se compreendeu na cotidianidade mediana, lançado em seu decair. A 
ekstase própria do decair é o presente, o presencizar. É o tempo com que lidamos na cotidianidade, o tempo público: uma sequência ininterrupta de agoras, em que o passado, o presente e o futuro se veem separados. Mas é precisamente esse tempo público aquele requerido pela ética tradicional. Por exemplo, no arrependimento, no remorso, no perdão ou no agradecimento pelas ações passadas, no agir coerentemente, mantendo determinados princípios ou atitudes ao longo do tempo; a amizade como uma forma de interação com os outros que toma tempo; e muitos outros assuntos éticos tais como a ingratidão, a retaliação, a temperança, a paciência, etc. que pressupõem um tempo linear e sequencial que passa e deixa traços.

Para a ética tradicional, o tempo há de ser sequencial, separando o passado, o presente e o futuro, numa linha virtualmente infinita. Os elementos da moralidade pressupõem esse tipo de temporalidade: o comprometimento de um contrato realizado no passado e que precisa perdurar; uma promessa que deve ser cumprida no futuro, etc. Esses elementos da moralidade requerem um tempo sequencial, o tempo que passa, para serem realizados. Em termos da analítica existenciária, o Dasein, quando assume a atitude ética em sentido tradicional, presenciza as suas possibilidades existenciais. $\mathrm{O}$ passado, o presente e o futuro impróprios são concebidos enquanto agoras e, assim, presencizados. As promessas do passado, o cálculo para as consequências no futuro, etc. pressupõem o agora da ação ética. As ações éticas, nas abordagens tradicionais, só se realizam no agora, seja naquele que passou, seja naquele que ainda está por vir.

Isso se afasta completamente da decisão antecipatória do Dasein na temporalidade da existência. Esta se abre na ekstase do futuro, sendo presente nada mais que o instante da decisão que antecipa o porvir (projetivo, compreensivo) e retoma o ter sido, a facticidade. Ao que tudo indica, o futuro na ética tradicional está num mero aguardar: as promessas, o cálculo, o comprometimento, entre outras, aguardam um futuro de um agora em que as promessas serão cumpridas ou as consequências do ato ético ocorrerão. Em vez do tempo sequencial, a temporalidade originária da existência une as três ekstases, passado, presente e futuro, na decisão antecipatória do Dasein, decisão à qual o Dasein é aberto em um estado de ânimo fundamental como a angústia, que o desconecta do mundo-ambiente e, assim, de qualquer ética que esteja instalada na cotidianidade mediana. A temporalidade originária funda-se no instante da decisão, em 
que o Dasein se vê em seu puro ser-no-mundo, aberto a suas possibilidades, das quais as éticas tradicionais estão ali disponíveis entre outras tantas possibilidades.

Assim, resumindo, os três elementos da analítica existenciária de Heidegger (ontologia fenomenológica, Dasein e temporalidade) parecem rejeitar as articulações da ética tradicional em geral, não de uma maneira argumentativa, mas se diria que quase espontaneamente. Os valores éticos não aparecem numa fenomenologia descritiva do ser, o ser humano como Dasein não é definido por propriedades e não pode submeter-se a exigências éticas tradicionais que não estejam mediadas por projetos existenciais, sempre transcendidos, e a temporalidade da existência não é a temporalidade linear da ética tradicional. Elementos como facticidade, possibilidades de ser e transcendência obstaculizam o projeto moral que, como parte da metafísica, exige estabilidades, essências e finalidades. A ética tradicional, e com ressalvas, poderia, no máximo, considerar-se como uma possibilidade do Dasein, condizente com seu modo de ser decaído e impróprio; da qual, porém, o Dasein pode ser removido em qualquer momento pela voz da consciência que clama para uma decisão de si mesmo, que nunca pode se resumir numa decisão ética em sentido tradicional, ou que, inclusive, pode ser uma decisão contrária às regras da moralidade, nas abordagens tradicionais.

\subsection{Rejeição existenciária das éticas tradicionais em particular.}

Vimos como a filosofia de Heidegger, por sua própria constituição, rejeita a ética tradicional como atitude e ponto de vista sobre o mundo, pautando-se nos principais elementos de seu pensamento: método, concepção do humano, temporalidade. Mas a ética se desdobra em muitas e diversas teorias éticas, como as expostas no capítulo primeiro deste trabalho. Neste ponto, poderíamos partir para a análise do modo como cada teoria ética tradicional, na análise de suas particularidades (virtudes, deveres, consequências), vê-se rejeitada pela ontologia fundamental. É o que tentaremos nesta seção.

A princípio, não seria preciso realizar uma análise específica da rejeição dessas éticas, dado que, se os elementos existenciários apresentados pela análise de Heidegger, como procuramos mostrar, rejeita a ética tradicional de um modo geral, as teorias éticas 
particulares também seriam rejeitadas por extensão. Porém, esta análise de pormenor, mesmo que teoricamente desnecessária, pode ser conveniente para mostrar aspectos relevantes da rejeição existenciária da moralidade, com todas as suas consequências, mesmo que, inevitavelmente, haja algumas repetições e superposições com o que já foi exposto na seção anterior sobre a rejeição geral da ética tradicional.

\section{$\underline{\text { Rejeição existenciária da eudemonia e das virtudes }}$}

Das teorias éticas apresentadas, a ética aristotélica é talvez a que mais condiria com a analítica do Dasein, porque o homem virtuoso em Aristóteles é um indivíduo que não segue regras estritas e externas, mas antes possui essa espécie de saber (a sensatez) que o leva a um bem lidar com os acontecimentos, com as coisas e com as outras pessoas. O virtuoso, também na análise de Max Scheler, como vimos, é este ser humano que assume um modo de ser variado que o permite ver e lidar bem com o mundo; seu caráter virtuoso dota-o de certo trato que o leva a agir bem naturalmente. Isso faz-nos lembrar da "familiaridade" que o Dasein, enquanto ser-no-mundo, mantem com os entes ao seu redor, humanos e não humanos. Assim, poderíamos entender que ser virtuoso é um modo de o Dasein lidar com os entes e lidar consigo mesmo, ou seja, um modo de "compreender" a sua existência. Todavia, o pensamento acerca das virtudes traz outros elementos que inevitavelmente serão rejeitados pela ontologia fundamental e pela analítica existenciária.

Em Aristóteles as virtudes estão relacionadas a um "fim" do ser humano, que seria a felicidade (autorrealização). O filósofo supõe que tudo que existe tenha um fim, um télos, que seria seu bem. O fim de um violão está em sua sonoridade, e de um bom violão numa boa sonoridade. Essa teoria dos fins dos entes em Aristóteles pode ser entendida, dentro da analítica heideggeriana, do seguinte modo: os entes se apresentam ao Dasein de variadas formas, tendo um "para que...", uma serventia. Eles se apresentam dentro de uma conjuntura sem a qual esse "para que..." não se daria. Por exemplo, tenho este computador, junto com textos e anotações para o meu estudo. Assim, de algum modo podemos dizer que o fim deste meu computador, dentro dessa conjuntura, seria produzir textos. Mas dentro do complexo de utensílios, como exposto em Ser e tempo, não se pode definir o que seria o "bem" ou o "fim" próprio a esse ente, 
haja vista que, dependendo da conjuntura, os entes podem ter diversos fins. Um lápis, no modo de ser do utilizável, pode servir para a escrita, mas também para prender o cabelo e fazer um coque. Além disso, ele próprio pode ser um objeto de estudo, algo presente aí, do qual se analisam suas propriedades físicas e químicas; ou seja, apresentase no modo da subsistência. Em suma, na complexidade do mundo, os entes têm variados modos de ser, o que dificultaria indicar-lhes algum fim específico.

Poder-se-ia alegar que Aristóteles devia saber disto perfeitamente (o mundo já era complexo na Grécia antiga). Ainda se pode encontrar nos escritos de Aristóteles uma variedade de modos de ser dos entes no que diz respeito a seus fins, por estes poderem ser intermediários, últimos ou mesmo fins em si próprios. $\mathrm{O}$ mesmo ente pode ser tanto fim intermediário quanto último. O papel, por exemplo, pode ser um intermediário para se fazer um relatório; pode ser fim último; mas esse relatório pode ser também um intermediário se pensarmos que ele está voltado a outro fim, que é a pesquisa científica. $\mathrm{Na}$ concepção aristotélica, as virtudes são fins em si mesmas porque bastam por si só, mas também são intermediárias para um fim último, a saber, a felicidade, autorrealização do ser humano. Todavia, mesmo com essa tipologia dos fins, Aristóteles preserva um fim especificado para cada ente segunda a sua natureza, embora esse fim possa servir para outro (sendo assim intermediário) ou ser por si mesmo (fim último). Essa especificação do fim ou bem "natural" de um ente não pode aparecer na analítica de Heidegger, hajam vista os vários modos de ser dos entes não humanos, que sua fenomenologia revela, e a impossibilidade de atribuir um fim único e natural ao ser humano. Em Aristóteles, ficaria encoberto que o fato de que o ser, que é sempre ser dos entes, desvela-se em diversos modos de ser. os entes se apresentam de variadas maneiras, podendo ter distintos "para que...". Mas com isto, dilui-se a própria noção clássica de "fim", tal como aparece em Aristóteles e outros autores antigos. Se há muitos fins, não há nenhum fim.

Se é complicado atribuir um fim aos entes de um modo geral, segue-se que ao Dasein, também este um ente, não se lhe pode atribuir um fim. Mas o caso do Dasein é especial: não tem um fim pelo mesmo motivo que os outros entes, mas tampouco tem um fim em virtude de seu próprio modo de ser. Os existenciários do Dasein, que a analítica existenciária apresenta, são diversos e, enquanto modos de ser, podem se apresentar de distintas maneiras: há vários modos como, por exemplo, o discurso se 
realiza: no silêncio, na escuta, na escrita e suas diversas especificações: escrever cartas, escutar o motor do carro, calar-se para prestar a atenção, etc.. Essa variedade dos existenciários impede qualquer direcionamento único.

Um caráter de ser do Dasein que importa ainda salientar na questão dos fins é a facticidade da existência. A abertura de um estado de ânimo aponta para o ser lançado, para a facticidade do Dasein. Simplesmente a partir do nada, pela força de um estado de ânimo como a angústia, o Dasein é retirado de seu mundo ambiente; desfamiliariza-se, desloca-se da cotidianidade mediana. Para quê? Para nada, simplesmente acontece. Isso indica, segundo Heidegger, a facticidade da existência. A facticidade nada mais é do que a sua gratuidade. O Dasein está tão-somente jogado aí, aberto ao ser, em meio aos entes. Mas se a existência é gratuita, então não tem um fim, pois uma finalidade a tiraria da sua total gratuidade, daria à angústia uma direção, um télos. A existência do Dasein não tende a nada, não tem razão de ser. E se não tem um fim, não poderá "autorrealizarse" no sentido recomendado por uma ética eudemônica.

Além disso, não cabe ao Dasein uma definição por propriedades, como sim o admite Aristóteles; a atribuição de propriedades é fundamental para indicar algum fim do ser humano. Este, segundo Aristóteles, se distanciaria dos outros seres vivos por ter uma alma racional. Assim, é por essa propriedade própria do ser humano, o animal de $\operatorname{logos}$, que veríamos qual seria o fim do ser humano, como uma vida guiada pela razão ( $\log o s)$, como a vida ativa do sensato ou mesmo (e talvez sobretudo) como uma vida contemplativa. O Dasein, por seu turno, não se define por propriedades, mas se desdobra em modos de ser, o que indica que não poderia ser definido já que os existenciários são justamente formas de indefinição.

Porque o Dasein é marcado por existenciários, e não por propriedades, é que ele pode ser racional ou mesmo não sê-lo. Tudo o que era essência agora se torna possibilidade. A racionalidade é uma possibilidade ôntica do Dasein, que nada diz sobre seu modo de ser. E como possibilidade ôntica pode ser transcendida, pois que não há na existência uma escolha definitiva pela racionalidade, mas um projeto existenciário que teria de ser mantido nessa direção. Dessarte, não se pode retirar do Dasein um télos a partir de uma propriedade que o definiria, visto que não é um ente de propriedades; estas estão sempre mediadas pelo crivo das possibilidades da existência. 
Alguém poderia, depois de ler os textos de Heidegger, falar da autenticidade da existência como sendo um fim do Dasein. Isto é assim? Sabemos que a existência mesma chama, através da voz da consciência, à autenticidade, o que pode parecer que é próprio da constituição do Dasein seguir esse chamado. Nesse sentido, a existência autêntica poderia ser o télos do Dasein. Mas logo vemos que isso é algo muito diferente de um fim aristotélico, já que a autenticidade não indica nem recomenda um modo de vida específico (como, por exemplo, a vida contemplativa) nem pressupõe propriedades que o constituiriam como Dasein e, num âmbito estrutural, visaria algo como uma "realização" da sua essência de humano. Não há nada disso; em vez da racionalidade do animal de logos, encontramos apenas o poder-ser fático do Dasein. Também não há qualquer "vida superior" do Dasein, visto que qualquer modo de vida pode em tese estar ligado à existência autêntica e, pela singularidade que esta requer, um específico modo de vida pode ser um projeto existenciário autêntico ou inautêntico, assumindo o simesmo do Dasein ou o modo de ser de a-gente. Nessa esteira, também não haveria virtudes que levariam o Dasein para a existência autêntica, pela mencionada singularidade do poder-ser fático do Dasein próprio; a existência autêntica não requer especificamente alguma virtude, como mesmo pode prescindir de virtudes. Além disso, não carregaria nenhum traço valorativo, haja vista que a autenticidade é simplesmente modo de ser, como o decair, e não há nada que indique uma pretensa superioridade entre uma e outra; existência autêntica não é o mesmo que existência superior, e não pode funcionar como um télos.

Poderia o tema da "voz da consciência" em Heidegger ser lido num sentido teleológico? A voz da consciência aponta à decisão do Dasein pelo seu poder-ser mais próprio, que costuma estar encoberto na cotidianidade mediana, no mundo das ocupações do Dasein. Entretanto, o poder-ser, sabemos, é a estrutura mesma do Dasein, de modo que ela está sempre aí, mesmo que encoberta. O Dasein é sempre um poder-ser fático. Assim, não seria um télos a ser "realizado" (entre aspas, pois que realização implica efetivação e, no caso, realização do poder-ser seria abertura para as possibilidades, não efetivá-las); o chamado da "voz da consciência" é da decisão pelo poder-ser que o Dasein já sempre é, embora encoberto na cotidianidade. Apesar do chamado da voz da consciência, pode-se afirmar que a autenticidade, assim como a propriedade, são formas de o Dasein se projetar e que, no fundo, são possibilidades, 
sendo somente que algumas estão mais abertas ao ser. A tentativa de se pensar a autenticidade do Dasein como um télos teria que entender essa noção em um sentido bastante lato, de modo que perde o que ele realmente quer dizer. O télos tem a ver com uma realização de uma propriedade essencial de um ente, o que a existência autêntica nunca poderia ser.

Depois de rejeitado algum télos do Dasein, podemos - ainda dentro do escopo das éticas de virtudes - questionar sobre a possibilidade existencial, no plano ôntico, de uma vida virtuosa. Embora nada indique que a vida virtuosa seja o fim do humano ou mesmo uma espécie de plenitude, ela é, certamente, uma possibilidade. Ora, é bastante comum em nossas vidas buscarmos orientações acerca de nosso viver, sobre formas como podemos tocar nossas vidas para frente. Uma delas é a vida virtuosa. Pensando na ética de Aristóteles, mesmo se o Dasein direcionasse a sua existência para uma vida teorética, projetando-se de modo a viver de forma contemplativa para melhor realização do seu télos humano, nada disto garantiria a ele ficar fixado nessa forma de vida, visto que a sua existência o faria transcender aquela escolha. Além disso, nada impede que a vida teorética possa ser um encobrimento da existência própria do Dasein; este pode se projetar nessa vida teorética assumindo o si-mesmo de a-gente, e viver assim porque se vive, porque todo mundo vive. Ser um peripatético, tornar-se um sábio, seja na forma virtuosa clássica, seja na forma da erudição intelectual de hoje, não implica autenticidade (se é que se encontra aí), pois poderia tratar-se de apenas uma adesão a algo que está sendo feito e recomendado.

Assim, poder-se-ia dizer que a vida virtuosa é uma possibilidade do Dasein, que pode ser autêntica ou não. A indicação do que seria virtuoso ou vicioso não se encontra na ontologia do Dasein, apenas nas maneiras ônticas de ele compreender a sua existência. As virtudes e os vícios podem ser dissolvidos nos modos de ser do Dasein, que pode não distingui-los. O medo é considerado um vício em Aristóteles e, para Heidegger, um estado de ânimo que prende o Dasein em seu mundo-ambiente, afastando-o de seu poder-ser. Isto poderia sugerir uma aproximação entre ambos os filósofos. Contudo, essa aproximação é inadequada: os estados de ânimo do Dasein não podem ser considerados "virtudes ontológicas", nem tampouco vícios. Segundo Aristóteles, agir por medo é uma insensatez, ou seja, não agir bem racionalmente; em Heidegger, o medo afasta do poder-ser fático; a angústia, por seu turno, é um estado de 
ânimo que aponta para esse poder-ser, porém dificilmente poderíamos associar o páthos da angústia com algum tipo de virtude, e o Dasein angustiado com um virtuoso.

Na sua busca da vida virtuosa, o sensato tentaria não se deixar abater pela angústia, na medida em que esta o atrapalharia a lidar com as coisas e com os eventos; mas é justamente esse atrapalhar em que consiste o estranhamento provocado pela angústia, demovendo o Dasein das ocupações em que fica habitualmente preso, fazendo com que os entes se apresentem em sua totalidade enquanto possibilidades. De alguma forma, o Dasein entrega-se à angustia, como abertura ao ser. Pelo contrário, deixar-se levar por um estado de ânimo seria perigoso para um virtuoso aristotélico, que tem sempre de tentar manter seu bem lidar com os eventos, as coisas e os outros. O virtuoso tem seu modo próprio de ocupação e preocupação com os outros, que a angústia pode deixar em suspenso. Isso já aponta para uma característica fundamental do virtuoso que, no entanto, não condiz com a existência do Dasein: o virtuoso permanece preso em seu mundo-ambiente, deixa-se levar ainda por suas ocupações, tentando apenas melhorar seu valor. Ele tem de estar atento ao que o mundo a sua volta lhe apresenta para um bem lidar, o que significa perder-se de seu poder-ser. $O$ virtuoso trabalha com as possibilidades das coisas que estão se apresentando, o que se difere da possibilidade do poder-ser do Dasein, que o abre para diversos projetos que seriam impensáveis para um virtuoso.

\section{$\underline{\text { Rejeição existenciária do "senso moral" }}$}

A afirmação do senso (ou sentimento) moral retira da razão o fundamento da moralidade, contra uma longa tradição no pensamento europeu. Não é do âmbito da razão, segundo David Hume, a moralidade, mas antes esta se vê apoiada em sentimentos de agrado ou de repulsa, bases para a visualização da virtude e do vício. Isto é característico de uma abordagem empirista da moral, fortemente baseada em modos de percepção.

Tanto Hume quanto Heidegger estariam de acordo com a inexistência de "fatos morais". Hume nos fala que, diante de um evento, podemos notar sentimentos, intenções, movimentos, mas não podemos perceber a moralidade. Ela não está lá. No 
entanto, nós quando nos deparamos com certas situações, temos determinados sentimentos dos quais se derivam o vício e a virtude. Em Heidegger, também não haveria o "fato moral", pois que em sua fenomenologia aparecem apenas modos de ser dos entes, e não valores. Os valores e fatos morais não são caráteres de ser, eles próprios não poderiam ser tratados como entes. Os pretensos "fatos morais" se dissolvem, em todo caso, nos projetos do Dasein, em seu modo de compreender-se; os valores e o julgamento moral são modos como o Dasein compreende-se existenciariamente. Todavia, os valores desaparecem, para Hume e Heidegger, em contextos filosóficos muito diferentes.

Assim, num assassinato, Hume veria movimentação de corpos, gritos, sentimentos de raiva, medo, sensação de dor, em suma, tudo o que pode ser resumido numa análise de cena de crime; porém, a moralidade não se encontra aí, mas na percepção que temos ao nos depararmos com o acontecimento. A moralidade fica perto da psicologia. Heidegger, por seu turno, dissolveria essas ações em formas de ser-com; o assassinato é um modo da preocupação, entre tantas outras efetivas possibilidades de lidar com o outro. Também não se vê a moralidade aí, pois que esta é também uma outra forma de projetar-se; “julgar moralmente” é uma possibilidade do Dasein entre outras. Em suma, enquanto Hume dissolve a moralidade em dados empíricos, Heidegger veria nos discursos e manifestações morais apenas formas de projetos existenciários do Dasein.

A fundamentação da moral em Hume, no entanto, pressupõe uma distinção entre objetivo e subjetivo, que não faz sentido na fenomenologia de Heidegger. Segundo Hume, não vemos nenhum "fato moral" objetivo, mas temos, sim, uma sensação, um sentimento (subjetivo) ao nos depararmos com um acontecimento que nos afeta, positiva ou negativamente. $\mathrm{Na}$ analítica existenciária, não existe "fora" e "dentro", “objetivo" e "subjetivo". Tanto uma verificação empírica, "objetiva", quanto no caso de um sentimento pessoal diante de um fato, são ambas formas de abertura, modos pelos quais o ser dos entes se desvela ao Dasein, sendo assim que essa distinção não é fundamental. Um sentimento seria, para a analítica existenciária, tão objetificante (no sentido de atribuir uma essência fixa) como um fato.

Antes de um "sentimento moral", o Dasein está em estados de ânimo, os quais são, em vez de características empíricas, modos de ser do Dasein. O Dasein está sempre 
em um estado de ânimo, que são formas de abertura; de modo que não há uma forma "pura" de ver o ente que seja independente de estados de ânimo. Além disso, não há também distinção entre subjetivo e objetivo na medida em que o estado de ânimo não caracteriza simplesmente um "estado mental" de um indivíduo, mas algo assim como uma "atmosfera"; é um como do Dasein que não se restringe a um indivíduo, pois que pode ser como o ambiente em que se apresenta ${ }^{202}$. Assim, por exemplo, um indivíduo triste não fica com seu "sentimento" só para si, mas o ambiente todo fica como que entristecido nessa atmosfera, e também os outros passam a perceber as coisas desse modo. Ou seja, os estados de ânimo, como modos de abertura ao ser dos entes, não são, na analítica de Heidegger, "subjetivos" (nem "objetivos"; estão para além dessa distinção), nem psicológicos, mas estruturas existenciárias do Dasein.

Dessa forma, as aberturas dos estados de ânimo não indicam necessariamente uma forma de atitude ou "percepção" de eventos. E embora eles desvelem de formas distintas o ser dos entes, não apontam para uma efetivação ou concreção de objetividades. Isso já vimos no caso da análise da angústia e do medo. Este faz com que o Dasein fique atrelado ao mundo-ambiente, indo de ente e ente; enquanto aquele outro estado de ânimo, em vez de atrelar o Dasein aos entes, estranha-o, de modo que o Dasein perca qualquer relação com os entes e estes, então, aparecem apenas como possibilidades. Mas atrelar-se ao ente, no caso do medo, não indica que tipos de projetos se realizam, ou seja, o que o Dasein está efetivamente fazendo ao estar com medo. Com medo, alguém pode matar, ou ficar paralisado, ou esconder-se, ou encobrir-se com um cobertor na cama, ou dedurar alguém, etc.. Nada em específico o medo indica. Tampouco a angústia, esta que abre o Dasein ao seu poder-ser mais próprio, o que significa o desvinculo de uma relação concreta ou efetiva com o ente. Isso significa: os estados de ânimo não apontam para algum tipo de julgamento moral, pois que este é apenas uma possibilidade que as aberturas dos estados de ânimo apresentam, uma forma de projetar-se.

\section{Rejeição existenciária do contratualismo}

\footnotetext{
${ }^{202}$ HEIDEGGER, Martin. Os Conceitos Fundamentais da Metafisica. Rio de Janeiro, Forense Universitária, 2006, p. 80.
} 
Em Hobbes vemos o humano enquanto animal egoísta que, para evitar males maiores no eterno conflito do estado de natureza, aceita compactuar limitando as suas liberdades para ganhar em troca uma vida mais segura e feliz em uma sociedade de paz. O pacto social, segundo as teorias contratualistas, consistiria em regras com as quais um ser com determinadas características (razão, bom senso, liberdade, etc.) estaria de acordo para poder conviver com outros seres com essas mesmas características. Esse pensamento contratualista se baseia totalmente em atribuições de propriedades ao humano: animal egoísta, que age pelo medo ou por vã glória, dotado de razão a ponto de reconhecer leis de natureza e compactuar em prol de uma sociedade pacífica, embora que restrinja a sua liberdade natural. O humano está aqui totalmente caracterizado, de formas bastante limitadoras do modo de ser do Dasein, encobrindo seu ser-possível. Características como o egoísmo, o medo, a generosidade ou o desejo de segurança não poderiam ser postas como propriedades definidoras do Dasein, e sim, no máximo, como meras possibilidades da sua existência.

O egoísmo é apenas um modo de compreender-se. Tantas outras formas de agir com os outros são possibilidades efetiváveis do Dasein, como a solidariedade, a gentileza, a atenção, assim como o egoísmo e a guerra hobbesianas. A preocupação, o existenciário consistente na lida do Dasein com os outros, engloba todas essas possibilidades de ser, além de muitas outras não efetivadas, que caracterizam o ser-com. É um existenciário e, assim, não o limita a determinadas formas efetivas da relação com o outro, como o egoísmo e o conflito. O Dasein tem como possibilidades diversas formas de convívio com os outros, que não se restringem a uma guerra de todos contra todos ou a paz da sociedade civil. Não se poderia dizer que o humano é "egoísta por natureza" ou que "por natureza deseja a segurança". Na medida em que o contrato social surge dessas características, o Dasein tampouco está destinado "por natureza" à assinatura de contratos.

$\mathrm{Na}$ perspectiva da analítica existenciária, também não poderia haver uma forte distinção entre um estado de natureza e um estado de sociedade civil, como se fosse possível distinguir entre um Dasein antes e outro depois da sociedade civil. O Dasein pode projetar-se de diversos modos, preocupar-se com os outros de distintas maneiras, tanto na sociedade civil quanto no "estado de natureza", ou melhor, em uma forma de organização não estatal. Essa distinção, portanto, não é originária, nem o é a ideia de 
contrato. O Dasein poderia escolher não assinar contrato algum e viver de acordo com as suas forças naturais; e nada garante que esta não seja a sua escolha no futuro.

Mesmo a ideia de um contrato é complicada. Assumir um contrato, aceitar regras e submeter-se ao constrangimento do Estado, ações próprias ao contratualismo de Hobbes e seus continuadores, não somente são apenas possibilidades do Dasein, como elas não o podem restringir; aceitar sujeitar-se a regras parece fundamental ao Contratualismo; no entanto, o Dasein, enquanto estrutura existenciária, não pode ser constrangido por leis ou pelo Estado de forma absoluta, mas sempre no crivo de escolhas. Nada faz com que o Dasein siga regras a não ser um projeto de assim fazê-lo, projeto que, em qualquer momento, pode ser transcendido em direção a outra possibilidade. Noutros termos, o Dasein pode assinar um contrato, mas sempre o ultrapassa. Mais originário que um contrato hipotético fundante da sociedade civil é a decisão de si mesmo: tem de se saber o que o Dasein fará com o contrato em vez de se saber o que o contrato fará com o Dasein. Sentir-se constrangido pelo Estado é uma possibilidade, assim como a rebelião, o menosprezo pelo poder, a admiração ou mesmo a abolição do Estado. Uma política do Dasein não poderia constrangê-lo, mas de algum modo promover seu poder-ser em alguma direção.

Por fim, um elemento afetivo importante na teoria de Hobbes é o estado de ânimo do medo. Vimos que é pelo medo que o ser humano é levado ao contrato pela sociedade civil, e é também por esse mesmo estado de ânimo que a vida em sociedade é mantida, o medo diante do Leviatã que é o Estado. É também o medo da morte infringida pelo outro ou do castigo imposto pelo Estado. Em termos heideggerianos, o ser humano de Hobbes seria um Dasein em modo de ser bastante impróprio. Na analítica existenciária, como vimos, o medo é um estado de ânimo que faz com que o Dasein fique atrelado ao seu mundo-ambiente, projetando-se de ente em ente, encobrindo o poder-ser fático do Dasein; nesse sentido, a antropologia de Hobbes seria um encobrimento das possibilidades do Dasein, estas que, mesmo no estado de ânimo do medo, não se restringem aos modos específicos de se efetivarem como na análise do medo em Hobbes, que leva ao contrato e manutenção do Estado.

O medo, tal como funciona no contratualismo hobbesiano, é também medo da morte. Ora, sabemos que isso está relacionado a uma forma imprópria do ser-para- 
morte. Assume-se a morte como um evento que vai ocorrer algum dia, aquilo pelo qual se espera (temporalidade) e do qual se esquiva "por enquanto". A morte, no entanto, para Heidegger, é a possibilidade mais própria do Dasein, a possibilidade de sua impossibilidade, ou seja, de sua inexistência. A relação mais própria com a morte consiste no adiantá-la enquanto possibilidade, sendo assim o Dasein um ser-para-morte autêntico. Mas, precisamente, a fuga da morte enquanto um evento que ocorre ao ser humano e o ameaça, é aquilo que funda a sociedade hobbesiana e, assim, a sua ética do contrato. A ética de Hobbes, portanto, baseia-se em uma relação imprópria com a morte, de modo que assumi-la enquanto possibilidade mais própria, à qual apela o Dasein pela voz da consciência e pelo silêncio da angústia, pode significar a perda de toda a base para uma ética hobbesiana.

\section{Rejeição existenciária do utilitarismo}

O utilitarismo talvez seja a teoria ética que mais clara e facilmente fica rejeitada pela ontologia fundamental e a analítica existenciária, de modo que este texto não precisará se alongar demasiado, mas apenas entender o porquê dessa situação. Como dissemos na Introdução, Stuart Mill, embora pouco ou nunca citado por Heidegger (em contraste com Kant, Nietzsche e Aristóteles, filósofos sempre presentes em seus escritos), não necessariamente é desconhecido pelo filósofo alemão. Aliás, é pouco provável que Heidegger o desconhecesse, dados seus amplos estudos de história da filosofia europeia. Todavia, o modo como é facilmente rejeitado o utilitarismo pelos elementos existenciários pode sugerir uma explicação de por que Heidegger não dedica mais tempo à obra do autor inglês, sendo assim seu silêncio já um posicionamento filosófico. Pois possivelmente o utilitarismo seja a teoria ética que apresenta a imagem da vida humana mais objetivadora e ocultadora da existência.

A ética utilitarista de Stuart Mill, como foi exposto, indica de que maneira uma ação correta seria aquela que presumivelmente leva à felicidade geral, para o prazer ou ausência de dor da maioria. Essa correção, segundo o utilitarismo, poderia ser determinada mediante um cálculo. O cálculo para a ação correta não levaria em conta apenas a quantidade do prazer, mas, sobretudo, a sua qualidade, dado que há prazeres inferiores e superiores, sendo esses últimos os que normalmente trazem maior 
felicidade. Vemos que o utilitarismo, ao utilizar a noção de cálculo, supõe um humano e uma sociedade sujeitas ao calcular. Tal como apresentado, o cálculo apresenta um forte caráter nivelador, desde a estipulação daquilo que os humanos querem, até o agrupamento indiscriminado de indivíduos dentro do que se considera a "maioria". O nivelamento, como vimos na analítica existenciária, é algo relacionado à tendência do Dasein de se projetar no si-mesmo de a-gente, na dimensão do decair, encobrindo a sua singularidade. O nivelamento, portanto, pertence à dimensão imprópria do Dasein, um modo de compreender-se que encobre seu poder-ser fático. A noção utilitarista de "maioria" precisa de um tipo de nivelamento existencial.

No entanto, devemos ainda nos atentar nos detalhes dos variados modos como o utilitarismo pode ser nivelador. Um primeiro ponto está na própria noção de "felicidade". Independente da noção de felicidade que o autor possa trazer a tona - no caso, ligada a uma noção ampla de prazer -, não se pode determiná-la como algo que todo Dasein simplesmente almeje. Quando muito, pode-se observar, onticamente, que o Dasein cotidiano, em sua forma decaída no modo de a-gente, costuma, de fato, "buscar a felicidade" ou assim o manifestar em seu discurso, algo bastante repetido no falatório. Entretanto, mesmo o decair não indica uma universalidade de algum projeto ôntico definido (como querer a felicidade ou o prazer), pois que mesmo a cotidianidade, que delineia possibilidades e encobre outras, não determina algum projeto ôntico específico, mas muitos. O que se rotula como "felicidade" não faz jus a projetos muito variados. $\mathrm{O}$ Dasein se projetaria de modo que a felicidade enquanto prazer fosse algo a que ele desejasse. E, por ser projeto, ele é apenas um entre outros que o Dasein pode assumir; o Dasein feliz é apenas um modo de compreender-se.

O ponto é: não há nada ôntico (como a felicidade) que defina o Dasein, seus projetos; o querer e, mais especificamente, o querer a felicidade é apenas um deles. $\mathrm{O}$ Dasein não se guia pelo prazer, seja qual conceito esse termo tenha (utilitarista ou epicureu), mas pelo projeto existenciário, o qual, por ser um modo de ser em vez de uma determinação, abrange diversas possibilidades ônticas, entre as quais a "felicidade". Além do complicado pressuposto da "busca do prazer", temos como princípio ético utilitarista também a "maximização da felicidade", que mostra outro aspecto da atitude niveladora do Utilitarismo, que, em termos heideggerianos, tomaria o Dasein como um ente à mão, um ente disponível. Este é, possivelmente, o ponto 
fundamental pelo qual a rejeição existenciária do utilitarismo parece mais fácil e direta que no caso das outras teorias éticas. O humano é aqui tomado também como um ente utilizável e sujeito a cálculos, num tipo de coisificação do Dasein sem qualquer sensibilidade para a transcendência dos seus projetos.

A noção de cálculo a partir das consequências das ações claramente pressupõe uma temporalidade linear, em que o futuro é projetado enquanto um mero aguardar por consequências, num modo impróprio da compreensão. Tomam-se ações humanas no presente esperando que elas tenham consequências que maximizem a felicidade no futuro, num agora que ainda virá. No entanto, essas ações não são calculadas em cada circunstância, pois que o desenvolvimento da humanidade (que também demanda tempo linear) fez com que se estabelecessem muitas regras secundárias, estas que normalmente levariam a boas consequências para "a maioria". Essas regras parecem ser compartilhadas pelas pessoas de maneiras massificantes nos discursos humanos, o que pode ser relacionado com o existenciário chamado falatório. No falatório não se distingue a revelação do ser pela abertura da compreensão do que é meramente repetido pela fala. Assim, essas regras secundárias, em vez de serem abertas originariamente pela compreensão, podem ser simplesmente repetições automáticas do falatório.

\section{$\underline{\text { Rejeição existenciária do dever, da noção de pessoa e da vontade }}$}

A ética kantiana é uma ética do dever para um sujeito racional que é pessoa, um ser com dignidade. Os deveres morais são exigidos, e auto-exigidos, pela vontade livre desse sujeito racional. Vimos que outros filósofos posteriores, como Hegel, Schopenhauer e Scheler, desenvolveram de modo diferente as noções kantianas, se distanciando do pensamento ético de Kant. Mas, desde a perspectiva heideggeriana, no entanto, tanto a ética de Kant como esses novos desenvolvimentos seriam rejeitados pela analítica existenciária pelos mesmos motivos e com os mesmos elementos.

Entretanto, há algumas aproximações superficiais entre o pensamento kantiano e o de Heidegger. Por exemplo, aquilo que caracteriza o humano, tanto em Kant quanto em Heidegger, não se vincula somente com o ente humano, pois que se pode pensar em outros entes que possam ser racionais ou Dasein, entes não humanos que talvez nunca 
venham a existir. Kant sustenta uma ética do sujeito racional que não se restringe ao humano, mas a todo ente racional que possa vir a ser. De forma semelhante, o Dasein de Heidegger, embora designe o humano, é sobretudo um modo de ser que poderia convir a outros entes não humanos, sem manter um vínculo necessário apenas com a espécie humana.

Uma crítica muito comum contra Kant, que vemos, por exemplo, em Hegel e Scheler, é pelo chamado "formalismo ético". Isso porque Kant, antes de formular deveres específicos, formula um princípio moral como critério para depois se estipularem deveres; esses princípios são puramente formais, como a primeira formulação do Imperativo Categórico, a fórmula da Lei Universal. Essa crítica muito usual dirigida contra Kant tampouco seria frisada pela analítica existenciária, já que esse "formalismo" kantiano condiz em parte com a existência do Dasein que, de certa forma, aponta também para uma estrutura formal da qual, posteriormente, poderão tirar-se direcionamentos concretos. O Dasein é um ente que, por seu ser, é indeterminado; a sua existência caracteriza-se pelo poder-ser. Mesmo a voz da consciência, que é um chamado do Dasein, chama-o, como diz Heidegger, pelo modo do silêncio, pois que não delineia nenhuma possibilidade ôntica ao Dasein; ao contrário, aponta-o ao seu poderser mais próprio, em que o ente como um todo lhe aparece como possibilidade, não enquanto efetividade. Há, pois, também uma espécie de "formalismo" heideggeriano.

Porém, em Kant o "formalismo", apesar de ser também um tipo de indeterminação, consiste em um princípio moral de um sujeito racional como um guia para os deveres, o que já pressupõe a efetividade de um ser-possível e a propriedade da racionalidade de um sujeito. O princípio kantiano, dessarte, já estreita as possibilidades, pois que se trata de um critério que pressupõe regiões do ente (sujeito, razão) de certa forma privilegiadas: as possibilidades aí são diferentes deveres que podem ser universalizados sem cair em uma possível contradição. O poder-ser do Dasein, por seu turno, ultrapassa tudo isso, pois que a razão mesma seria uma forma entre outras de o Dasein compreender-se, uma possibilidade dos seus projetos, e nessa sua abertura ele não fica limitado à observância de deveres. Dever é algo externo ao Dasein, seja estipulado pela sua autonomia, já mediada pela propriedade da racionalidade, seja exigido pelas instituições sociais (Estado, família, comunidade) em que o Dasein verse-ia envolvido, como em Hegel. Mas a voz da consciência é intrínseca ao Dasein, parte 
de seu modo de ser, um de seus existenciários. Seu chamado é mais originário que qualquer forma de dever moral.

Malgrado as aproximações apontadas, pareceria que a maior parte dos elementos da ética kantiana seria rejeitada pela analítica existenciária de Heidegger. O princípio da Lei Universal, cujo "formalismo" aproximou-se de início com o caráter do Dasein, é uma forma de nivelamento e uniformização. A primeira formulação do imperativo categórico estipula que uma máxima, para ser genuinamente moral, tem de ser universalizável, ou seja, que possa valer para todos. Mas o Dasein, apesar de regularmente situado no modo de ser de a-gente, é originariamente um singular que não pode ser nivelado; seu nivelamento está vinculado apenas a uma forma imprópria de compreensão do seu ser, a um velamento de seu poder-ser fático. Ao frisar especialmente a universalidade sem exceção das leis morais, as éticas deontológicas são talvez as mais frágeis diante dessa crítica.

Por outro lado, a vontade, seja na noção kantiana de "vontade livre", seja na noção schopenaueriana de "vontade de vida", são duas formas de entificar o ser, de reduzir o ser à vontade (crítica que Heidegger aplica também a Nietzsche). O Dasein, pelas mesmas razões que não é um ser eminentemente racional, também não pode ser definido como um ser de vontade, ou volitivo. Pior ainda quando esta se concebe enquanto uma "coisa em si", como em Schopenhauer. Isto realiza, metafisicamente, uma identificação do ser com a vontade, entifica o ser. O ser não se limita a um ente, seja racional, sentimental ou volitivo, mas antes é condição para que o ente seja todas essas coisas. Não só o ser não se limita a um ente, como este pode aparecer de diversos modos, visto que o ser, que é sempre ser dos entes, desvela-se e encobre-se de várias maneiras. Não há, então, para Heidegger, nenhuma vantagem em ter superado o intelectualismo do passado, baseado na razão, por uma filosofia da vontade.

A concepção schopenhaueriana de vontade, quando instanciada no ser humano, faz com que sua vida seja marcada pelo sofrimento, pelo pêndulo entre a dor e o tédio. É uma filosofia com uma visão "pessimista" da condição humana. Esses elementos do pensamento de Schopenhauer, da mesma forma que a visão "otimista" de Leibniz, são totalmente irrelevantes na analítica existenciária, porque implicam uma valoração num mundo onde só o ser aparece e se oculta. O próprio dualismo "pessimismo-otimismo" 
deve ficar de fora como metafísico; não é tarefa da analítica da existência analisar a condição humana e verificar que ela é "boa" ou "ruim", adotando uma postura "otimista" ou "pessimista".

Curiosamente, apesar de ter uma teoria moral rigorista, Kant parece ter uma grande desconfiança acerca da existência efetiva da moralidade. Pois a sua formulação da ética baseia-se no que se supõe haver de inteligível no ser humano, de caráter racional e autonomia da sua vontade; a moralidade não poder se basear no que há de meramente natural no ser humano, este que tende a seguir suas inclinações, em vez de agir pelo dever. O humano, então, está dividido, segundo Kant, em um lado natural, em que é levado pelas inclinações, e um lado racional, sua parte inteligível, na qual se baseia a moralidade. A desconfiança de Kant a respeito da capacidade moral dos humanos provém de que são as inclinações que dificultam ao ser humano a agir corretamente, já que se ele fosse um puro ser racional, a sua vontade inevitavelmente coincidiria com o dever. A moralidade arrisca não surgir pela elevação da exigência e a fraqueza humana.

As dificuldades estruturais da moralidade, para Heidegger, não são desse tipo. O ser humano não está entregue às inclinações, mas, como Dasein, está desde sempre no decair, que é uma dimensão constitutiva do Dasein mas que o afasta da sua essência, do seu poder-ser mais próprio. Sobre o decair, no entanto, Heidegger procura mostrar que não consiste em um obstáculo moral ou algo do tipo, mas um modo de ser; apesar de desviar o Dasein de seu poder-ser autêntico, isso não constitui algum tipo de "falta moral", até mesmo porque a existência autêntica não implica moralidade ou imoralidade, como vimos. A voz da consciência, que é mais originária que algum imperativo ético, é o apelo do Dasein à decisão pelo seu poder-ser fático; e a culpa pela impropriedade da existência em que o Dasein se encontra no mais das vezes também não tem caráter moral, mas é anterior a isso, é também existenciário, uma constituição do ser do Dasein.

Assim, as dificuldades da moralidade são estruturais; não provém da elevação de um ideal moral inatingível por parte de um ser dominado pelas paixões. Também não faz sentido existenciário esta divisão entre um lado racional e outro natural do humano. Tanto as inclinações quanto a racionalidade são modos pelo qual o Dasein pode tentar 
se compreender. O Dasein, enquanto possibilidade, pode se projetar como um sujeito racional ou como alguém levado por inclinações, dentre muitas outras possibilidades. Essa dicotomia kantiana não pode ser entendida como uma situação objetiva (a luta da razão contra as paixões). A racionalidade enquanto uma possibilidade do Dasein nunca poderia ser algo como uma propriedade constituinte sua. O Dasein, a princípio, não é um ente racional, no sentido de definido pela racionalidade. Entretanto, isso não significa que seja "irracional", pois isto seria, igualmente, atribuir-lhe propriedades, só que negativas. A "racionalidade" alude a um conjunto de diversas possibilidades do Dasein de efetivar ou concretizar seu modo de ser, que transcendem o limitado conceito de ser racional utilizado nas éticas deontológicas.

Se o Dasein não se limita à racionalidade, ou não fica referido a algum dualismo entre um lado racional e inteligível e um lado das inclinações empíricas, também não pode ser caracterizado, como em Kant ou Scheler, como "pessoa". Dificilmente o Dasein poderia ser pessoa. Em primeiro lugar, porque pessoa é um conceito que atribui propriedades ao ser humano, e vimos que o Dasein não pode ser descrito ou delimitado através de propriedades. Além disso, a noção de "pessoa" tem claramente um peso valorativo, sobretudo em relação à "dignidade". Pelo próprio fato de ser pessoa esta já é “digna de respeito". Mas dignidade assim entendida é como uma atribuição extrínseca ao Dasein, algo que não lhe caberia sem antes passar pelo projeto existenciário. $\mathrm{O}$ Dasein não é digno ou indigno, mas pode ser projeto, falho ou bem-sucedido, de ser digno. A dignidade não é algo que lhe cai do céu, visto que é o Dasein um ente lançado aí. A facticidade, tal como a apresentamos, é uma dimensão que assinala para a gratuidade do Dasein: este é um ente que calhou de ser como é e tem de lidar consigo mesmo e com os outros entes. Ele é faticamente lançado ao mundo e é por ser no mundo fático que ele pode se compreender enquanto um ente que procura historicamente a sua dignidade transcendendo-a num projeto, sem que ela possa lhe ser atribuída mediante uma caracterização. Pessoa é ou uma atribuição externa - talvez afetada pelo modo de a-gente - é projeto histórico do Dasein; nunca algo intrínseco e garantido. 


\subsection{Metaética Heideggeriana}

Depois de todo o processo de análise da rejeição das éticas tradicionais - desde seus traços mais gerais aos mais particulares - por parte da analítica existenciária de Heidegger, tal como foi apresentada, em que procuramos mostrar a incompatibilidade entre os elementos que tradicionalmente compõem a ética e a estrutura do pensamento de Ser e Tempo, podemos agora procurar formular, de maneira mais específica e conclusiva, o que denominamos, no início deste trabalho, como uma metaética heideggeriana. É conveniente, primeiro, que retomemos o nosso diálogo inicial com a noção de metaética da Filosofia Analítica para expor de maneira mais clara o que pretendemos significar quando falamos de uma possível "metaética heideggeriana", não explicitamente presente em sua obra, mas reconstituível com os elementos expostos no presente trabalho.

Encontramos de imediato alguns traços comuns entre a metaética analítica e uma metaética fenomenológico-existenciária heideggeriana. A metaética heideggeriana, assim como a analítica, é também um discurso de segunda ordem ${ }^{203}$, haja vista que analisa os diversos elementos da ética em vez de procurar formular prescrições ou restrições de conduta, o que é próprio do nível ético. Ela é também, pois, descritiva. Porém, neste novo conceito de metaética - a metaética fenomenológico-existenciária -, ela não poderá ser entendida como um ramo da ética, ou como uma das duas subdivisões mais gerais, como o é no caso da metaética analítica, porquanto, como vimos, a própria existência da ética, ao menos em sua noção tradicional, é questionada pelos elementos fenomenológico-existenciários apresentados na metaética heideggeriana. Trata-se de uma curiosa metaética "dissolvente", que elimina sua linguagem-objeto. A metaética heideggeriana é de segunda ordem, na medida em que seu tema de estudo é a ética tradicional e seus componentes, e é também descritiva, mas essa descrição se apresenta no modo de uma rejeição total destes componentes e, assim, da própria ética, numa noção tradicional.

\footnotetext{
${ }^{203}$ MENDONÇA, Wilson. Questões metaéticas em: TORRES, João C. B. (org.). Manual de Ética. Questões de ética teórica e aplicada. Petrópolis: Vozes; Caxias do Sul: Universidade de Caxias do Sul; Rio de Janeiro: BNDES, 2014, p. 153.
} 
Outro ponto comum é que ambas as metaéticas não se ocupam com as especificações e controvérsias de cada teoria ética em particular, e sim investigam um arcabouço comum a todas elas. A metaética analítica supõe que exista algo como "um núcleo estável de considerações, atividades e pensamentos que define a ética convencional"204, de modo que ela não precise adentrar nas idiossincrasias ou controversas das éticas particulares, mas se debruça na análise desse núcleo comum. De maneira semelhante, a metaética heideggeriana, apesar de se ter realizado aqui uma análise de éticas particulares à luz da analítica existenciária, rejeita a ética tradicional de um modo geral, não em virtude de elementos particulares de cada teoria ética apresentada. A rejeição se deu fundamentalmente pelas concepções do ser humano, do tempo e do vínculo metafísico próprios a todas as teorias éticas tradicionais, e não a “idiossincrasias ou controvérsias das éticas particulares". A revisão pormenorizada da rejeição (das virtudes, do contrato, etc.) foi apresentada neste trabalho apenas como reforço argumentativo.

Mas apesar destas aproximações, há também distinções fundamentais entre a metaética analítica e a heideggeriana, sendo a principal, precisamente, o caráter redutivo ou dissolvente desta última, ao manter uma atitude radical a respeito do pressuposto da existência efetiva da ética em sentido tradicional, usualmente assumido por parte da metaética analítica. Nesta, como dissemos, a metaética se apresenta como um âmbito da ética que investiga descritivamente os conceitos e categorias morais utilizados pelas teorias éticas. Na metaética heideggeriana, por seu turno, a própria existência da ética em geral, na concepção tradicional que assumimos neste trabalho, é questionada pela análise fenomenológico-existenciária. Isso deve conduzir a duas concepções diferentes de metaética, malgrado as semelhanças.

Outro ponto importante que diferencia metaéticas analíticas de metaéticas fenomenológico-existenciárias de estilo heideggeriano está nas disciplinas envolvidas em cada caso. Áreas metaeticamente relevantes nas metaéticas analíticas são, pelo menos, a filosofia da linguagem, a filosofia da mente, a metafísica, a epistemologia e a psicologia moral ${ }^{205}$. A estas áreas correlatas, uma metaética heideggeriana deveria acrescentar, pelo menos, a Filosofia da existência, a Fenomenologia e a Ontologia, sem

\footnotetext{
${ }^{204}$ Ibidem, p. 155.

${ }^{205}$ Ibidem, pp. 155-160.
} 
deixar de interessar-se pelas áreas atendidas pelas metaéticas analíticas. Outra diferença importante é que a metaética analítica considera a divisão entre cognitivismo (proposições morais referem-se a algo no mundo) e não-cognitivismo (proposições morais são simplesmente manifestações expressivas, sem referências ao mundo) como básica $^{206}$. Numa perspectiva heideggeriana, essa distinção não seria originária, já que sendo as asserções éticas referenciais ou não, elas pressupõem, em todo caso, certas formas de compreensão do ser dos entes que pode ser discutida. Entrar nessa discussão, tentando descobrir se a postura de Heidegger seria cognitivista ou não cognitivista, pressuporia a existência da ética e de proposições éticas com sentido. A divisão entre cognitivismo e não-cognitivismo se dissolve na existência do Dasein e na sua temporalidade, junto com a própria ética tradicional, base dessa divisão.

A noção inicial de metaética que é utilizada neste trabalho é propositalmente ampla e consiste em qualquer consideração filosófica acerca da ética tradicional, abrangendo a possibilidade de que essa consideração seja um questionamento da própria existência dessa ética. Nesse sentido largo, tem sentido tentar reconstruir ume metaética na filosofia de Heidegger, estudando os modos como elementos fundamentais da filosofia de Ser e Tempo expurgam os valores éticos tradicionais pela força dos modos de ser do Dasein. Uma metaética heideggeriana consiste basicamente numa análise acerca da forma como a ética tradicional é rejeitada através de uma ontologia fenomenológica, uma analítica existenciária do humano e uma particular noção de temporalidade.

Do que foi exposto nas seções 3.1 e 3.2, podemos extrair agora um conjunto de teses metaéticas concretas que apontam para os diferentes modos pelos quais a ética, em sua concepção tradicional, é rejeitada. Vamos agora expor breve e explicitamente essas teses (ou metateses) dividindo-as em três tipos, seguindo os três âmbitos fundamentais nos quais se deu a rejeição existenciária das éticas: ontologia fenomenológica, analítica do Dasein e temporalidade. Cada tese metaética é seguida de breve comentário onde haverá, inevitavelmente, repetições. Mas antes disso, apontamos para uma tese metaética fundamental, anterior a todas as outras, que procura dar conta do ponto básico que fornece a ideia geral da metaética heideggeriana em seu caráter redutivo.

${ }^{206}$ Ibidem, p. 160. 
Tese metaética fundamental: A ideia de existir ética em sentido tradicional provém de um referencial metafísico em que o mundo se apresenta enquanto um conjunto de objetos, entes subsistentes, sendo que o ser humano se vê caracterizado por propriedades estáveis, como a racionalidade, que o constituem como um sujeito autônomo e responsável, que pode realizar ações éticas em um espaço de tempo. Com a destruição da metafísica, mudando o modo de acesso e a correspondente concepção do mundo e do ente humano, a ética tradicional se mostra como uma construção metafísica, que se dilui na existência do Dasein.

O ponto básico que subjaz a rejeição heideggeriana da ética tradicional é que esta se encontra vinculada com a metafísica, entendida enquanto ocultamento do ser pelo ente. Assim, a destruição da metafísica a partir da reflexão sobre a diferença ontológica entre ser e ente, da noção de humano enquanto Dasein, e o vínculo entre ser e tempo, implica juntamente a destruição da ética tradicional. Esta pressupõe um humano com determinadas propriedades que possibilitam sustentá-la; essas características do ser humano são o que promoveriam a atitude ética, esta que precisa de um curso do tempo para ser realizada. Tudo isso (que já trabalhamos nos textos anteriores e retomaremos nas teses metaéticas a seguir) vai de encontro ao pensamento ético, cujo liame com a metafísica faz com que ele pressuponha uma compreensão das coisas e do ser humano que não coadunam com o que Heidegger traz em Ser e Tempo, obra na qual ele procura desconstruir toda a empreitada metafísica. Por isso, Ser e Tempo não traz uma nova proposta de ética, haja vista que a análise fenomenológica é o puro tentar deixar o ser se apresentar em suas diversas formas e, sobretudo, o ser do Dasein, o ente que compreende o ser, sem qualquer tipo de valoração.

(1) Teses metaéticas ligadas ao método fenomenológico.

Tese metaética número 1. As éticas tradicionais lidam com valores. Valores em geral não aparecem numa descrição fenomenológica do mundo como entendida em Ser e Tempo.

$\mathrm{Na}$ fenomenologia de Ser e Tempo os valores não aparecem, não se mostram. Este é um ponto de incompatibilidade profunda com a ética, na medida em que esta não só 
trabalha com modos de ser dos entes, mas sobretudo com valorização desses entes e modos de se lidar com eles. A fenomenologia de Ser e Tempo não dá suporte para os valores em geral (estéticos, religiosos, etc) que as disciplinas normativas tradicionais precisariam para se realizarem, visto que os valores não são captados pela análise fenomenológica tal como Heidegger a entende.

Tese metaética número 2. As éticas tradicionais destacam certos tipos particulares de valores. Especificamente, não aparecem fenomenologicamente valores éticos, no sentido de orientações ou indicações de ser de uma forma ou de outra.

Se na fenomenologia heideggeriana não se mostram valores de um modo geral, logo não se apresentam especificamente os valores éticos nessa fenomenologia. Na ética tradicional, existem atividades melhores que outras, regras boas ou ruins, em suma, valorizações de diversos tipos; a ética tradicional precisa imperiosamente de valores para as indicações de ações, atividades e regras éticas e o estabelecimento de hierarquias e preferências. Não há na análise de Heidegger qualquer espécie de indicação acerca de ações, atividades ou modos de vida que sejam bons, corretos ou que tragam alguma forma de "melhoramento" da vida, da relação com os outros, com as coisas e com os eventos, seja evitando algum mal ou promovendo um bem; não se encontra nada que possa se apresentar com algum tipo de superioridade ou inferioridade (moral ou de qualquer outro tipo), nem maneiras corretas ou incorretas de ser. Os valores são modos ônticos pelos quais lidamos com os entes; porém, antes de qualquer tipo de valoração, e sem qualquer vínculo necessário com valores, há modos de ser, e são estes o que a fenomenologia investiga. Isto leva para a terceira tese.

Tese metaética número 3. A ética tradicional é trans-ontológica, transcende o mero ser para um dever-ser. Na fenomenologia de Ser e Tempo só aparecem modos de ser. Só pode haver fenomenologia do ser.

A fenomenologia considera como fenômeno apenas o mais originário, o ser em seus variados modos de manifestação, os diversos modos de ser. O que aparece são as diversas formas pelas quais o ser se mostra. Qualquer valoração é externa ao ser; certo modo de ser não tem em si mesmo nada que the garanta um sentido ou valor negativo ou positivo. Um caráter de ser transcende determinações de bem ou mal, bom ou ruim, 
certo ou errado. Mantendo-se na abertura fenomenológica ao ser, não cabem acentuações ou caracterizações valorativas. Uma fenomenologia do ser não proporciona elementos ontológicos para uma teoria ética tradicional. De uma ontologia não se pode passar para um plano normativo. Qualquer ética no sentido tradicional precisa ultrapassar o plano do puro ser.

Tese metaética número 4. Esses modos de ser podem ocultar-se ou velar-se; os valores (de qualquer tipo) não podem sequer velar-se, pois esse velar-se já seria uma parte de seu aparecer.

Os valores nem sequer estão encobertos, pois o encobrimento seria uma forma de manifestação. O mostrar-se originário do fenômeno abrange tanto o seu aparecer quanto seu encobrir-se, o desvelo e o velo. Por isso Heidegger pode falar em um encobrimento do ser na história da filosofia, pois que nesta o ser se vê posto como um ente (substância, cogito, Deus, etc.), ao qual nunca pode ser restringido, ainda que o ser possa se manifestar dessa forma (o ser é sempre ser dos entes, de modo que, quando há uma determinada notificação do ente, é porque é possível ao ser aparecer nesse ou naquele aspecto ôntico; por exemplo, mostrar-se enquanto ideia ou como substância). Já os valores não se velam nem se desvelam, pois que mais originariamente não se mostram em sentido fenomenológico. Podem aparecer entes que têm, dentre suas possibilidades de ser, o valorar, mas os próprios valores não aparecem. Assim, não há nem mesmo uma busca de valores ocultos em Ser e Tempo, visto que os valores não se mostram em seu sentido mais fundamental, que abrange tanto o desvelo (o sentido mais cotidiano de aparecer: estar à luz) quanto o ocultamento.

Tese metaética número 5. Elementos basilares das éticas tradicionais são modos de entificação do ser e, assim, encobrimento. Dessarte, a própria ética, em sua forma tradicional, é uma forma de encobrimento do ser.

As teorias éticas tradicionais lançam mão de certas determinações de ser em seu fundamento. Noções como pessoa, racionalidade, sentimento, vontade, etc. são entes tomados como dados, de sorte que deixam encobertas outras formas de manifestação do ser. A fenomenologia quer, justamente, descristalizar essas entificações do ser, este que nunca pode ser tomado como um ente. Dissolvendo-se essas determinações do ser - 
como vemos pela noção de Dasein, que transcende qualquer determinação (ou propriedade) do seu ser -, as éticas perdem seu ponto de apoio para a sua constituição.

Tese metaética número 6. As éticas tradicionais precisam de um ser humano capaz de criar valores. O ente mediante o qual acontece o acesso ao ser - o Dasein - é pura abertura compreensiva, ou seja, abertura ao ser dos entes, sem qualquer valoração.

O Dasein é o ente que compreende o ser; por isso a busca pelo sentido do ser, que é sempre ser dos entes, voltou-se à análise desse ente que tem em sua própria constituição uma abertura ao ser, que é compreensão. O Dasein compreende o ser na medida em que lida com os entes e consigo mesmo; em seu lidar, o ser dos entes se apresenta ao Dasein, como, por exemplo, o modo de ser do utilizável, uma das formas de aparição dos entes do seu mundo-ambiente. Esse seu modo de compreensão, portanto, é simplesmente abertura ao ser, não tendo relação com algum tipo de valor. O Dasein se abre originariamente ao ser dos entes, sendo os valores apenas formas ônticas pelas quais o Dasein pode se relacionar com os entes na cotidianidade, mas que não aparecem na abertura compreensiva, esta que é sempre abertura ao ser.

(2) Teses metaéticas ligadas à analítica do Dasein.

Tese metaética número 7. A ética (o ponto de vista ético), em sua concepção tradicional, pressupõe um ser humano com propriedades. Ela não pode ser constituída por um ente que não admite ser definido por propriedades subsistentes, mas consiste apenas em possibilidades de ser.

As éticas tradicionais de um modo geral entendem o ser humano como constituído por certas propriedades. Elas lhe atribuem predicados, sejam positivos, sejam negativos, que devem ser trabalhados, evitados, substituídos, etc., para a promoção da ética. $\mathrm{Na}$ filosofia de Hobbes, por exemplo, o ser humano é um animal egoísta que deve ser freado pelo Estado para evitar uma guerra de todos contra todos; as propriedades da racionalidade e do medo da morte fazem com que ele perceba que o contrato social é o 
melhor para um bom convívio e para sua segurança. Na teoria de Kant, o humano tem as propriedades de ser pessoa, de ser racional embora levado por inclinações; a sua racionalidade promove a ética, mas as inclinações dificultam um agir ético. A ética aristotélica procura um modo de vida que mais condiz com o predicado que distingue o ser humano dos outros seres, a sua racionalidade (logos). Todas essas éticas tradicionais supõem na sua base certas propriedades do humano, que devem ser procuradas, promovidas, amenizadas ou extirpadas. O Dasein, por seu turno, não pode caracterizarse por predicados, mas por um modo de ser, pelos existenciários, os quais, antes de determinações, são aberturas para possibilidades. A noção de humano enquanto Dasein rejeita propriedades e, portanto, elimina os elementos fundantes das éticas.

Tese metaética número 8. A ética tradicional precisa de um ser humano com uma essência. Ela não pode ser constituída por um ente cuja essência consiste em existir/ecsistir (ek-sistere) de maneira projetiva e transcendente.

As éticas tradicionais pressupõem um ente com características estáveis para o cumprimento das determinações éticas. O Dasein consiste na inconstância do poder-ser que é de sua essência enquanto existência. As ações éticas tradicionais se apresentariam, quando muito, enquanto possibilidades com as quais o Dasein compreende-se, projetase, entre tantas outras. Isso retira o caráter de exigência ou de recomendação próprio às ações éticas em sentido tradicional, pois que nada de especial as destacariam de outras, do ponto de vista ontológico, e nada faz com que o Dasein se prenda a essas possibilidades, dado que é o ente que transcende aquilo que é, pode sempre se projetar de diversas maneiras. O Dasein não pode nunca ficar no dado (numa determinada exigência de ser) sem já ir além.

Tese metaética número 9. A ética tradicional precisa de um ser humano capaz de sobrepor-se claramente aos entraves da sua ação. Ela não pode ser constituída por um ente que é apenas um poder-ser singular e que, na maior parte das vezes, está em estado de decaída na cotidianidade mediana; poder-ser singular e decair são dimensões ontológicas, que passam ao largo de algum valor moral.

O Dasein, por sua própria constituição, decai nas possibilidades da cotidianidade mediana, deixando encoberto seu poder-ser mais próprio. Já pareceria difícil para um 
ser "decaído" agir de acordo com as exigências das éticas tradicionais. Mas tanto o assumir seu poder-ser fático quanto o decair na cotidianidade são modos de ser do Dasein, sem nenhuma conotação valorativa. Não podem ser interpretados moralmente. O decair não tem um sentido negativo como o nome poderia indicar, nem o poder-ser fático teria um valor positivo em si por condizer com o mais próprio modo de ser do Dasein. São somente caráteres de ser do Dasein, que indicam simplesmente o modo em que a essência do Dasein aparece (poder-ser) ou encobre-se (decair). Assim, não faz sentido uma interpretação moral desses modos de ser do Dasein.

Tese metaética número 10. A ética tradicional precisa de algum tipo de necessidade. Ela não pode basear-se em um ente lançado na sua facticidade, na gratuidade da existência.

A facticidade da existência indica que o Dasein desde já se encontra jogado "aí" no mundo, ou seja, que está simplesmente entregue à abertura do ser dos entes. Não há nada que indique um porquê disso, o Dasein é apenas, gratuitamente, um ente "aí" no mundo. Isso nega uma interpretação teleológica do ser humano, o que é essencial para éticas que procuram indicar um caminho para se alcançar o "fim" do ente humano, seja algo que todos desejariam, ou mesmo a própria realização de sua essência (seu télos). $\mathrm{O}$ Dasein lida com os entes e consigo mesmo facticamente, sem nenhuma indicação do que deve fazer com seu ser que não seja meramente ôntica; é um desamparo ontológico do seu poder-ser fático.

Tese metaética número 11. A ética tradicional precisa de uma consciência moral. Ela não pode ser constituída por um ente cuja voz da consciência não lhe indica nenhuma direção a seguir mas o lança para a plenitude de suas possibilidades sem qualquer auxílio para as suas decisões.

O Dasein é um poder-ser singular, embora isso fique encoberto nas vicissitudes da cotidianidade, em que o Dasein se compreende enquanto a-gente. A voz da consciência é o existenciário que o retira da cotidianidade, levando-o à decisão pelo seu si-mesmo. Mas esse existenciário não tem nenhuma conotação moral, é simplesmente o modo pelo qual o Dasein é entregue à decisão pelo seu si-mesmo mais próprio, sem alguma indicação de qual escolha tomar. Ela discorre pela voz do silêncio, o que significa que 
não delineia alguma ação efetiva, mas para a pura possibilidade fática. Não somente não indica o que fazer consigo mesmo (seu si-próprio), como o retira de qualquer projeto em que o Dasein esteja envolvido na cotidianidade, seja ético ou não. Em suma, não tão-só a "voz da consciência" não tem uma conotação moral (pois que é entrega do Dasein à decisão pelo si-mesmo, abertura às suas possibilidades, sem nenhuma indicação efetiva), como poderá retirá-lo de algum projeto moral da cotidianidade.

Tese metaética número 12. A ética tradicional precisa de estados de ânimo onticamente encorajadores. Ela não pode ser constituída por um ente que se angustia, e em seu angustiar-se se isola do mundo dos entes a sua volta e dos outros e é lançado para sua solidão mais profunda.

Num estado de ânimo fundamental como a angústia, o Dasein desfamiliariza-se dos entes a sua volta, sendo assim retirado de sua cotidianidade mediana. O Dasein perde o vínculo com os entes: a lida com os utilizáveis, a relação com os outros. É lançado à solidão do seu poder-ser. No âmbito da ética tradicional, isso significa que a angústia o retira de uma possível "sensatez" ou "sabedoria", impossibilita algum cálculo das consequências de uma ação, afasta-o de imperativos ou de qualquer regra de conduta, seja de família, do Estado, ou de uma atividade qualquer. Desfamiliarizado com o mundo, o Dasein desengaja-se de qualquer projeto de ser num sentido ético.

Tese metaética número 13. Em muitas éticas em sentido tradicional, e talvez em todas elas, precisa-se de uma noção de finalidade. O Dasein não pode guiar-se por fins últimos ou teleologias, de maneira que não pode ser virtuoso nem se autorrealizar através do exercício das virtudes.

Como expresso na tese 10, a facticidade elimina a noção de fim no Dasein, e segundo a tese 7, o Dasein não se define por propriedades. Isso rejeita a ideia ética de fim e autorrealização do humano, visto que o Dasein não tem télos a ser atingido, nem se caracteriza por propriedades que deveriam ser promovidas. A existência autêntica, em que o Dasein exerceria seu poder-ser fático e singular mais próprio, não pode ser entendida enquanto "autorrealização" do Dasein, haja vista que ela implica abertura a possibilidades, não modos de agir efetivos. O Dasein já sempre é esse poder-ser, embora possa estar encoberto na cotidianidade; assim, não haveria uma "realização" 
dessa sua essência, pois que nunca deixa o plano do seu poder-ser. E essa sua essência, o poder-ser, se dá independentemente de virtudes, ou mesmo indo de encontro a estas; não há nada que a ligue com virtudes ou vícios. A existência autêntica sequer carrega uma "superioridade" em vistas a um fim, pois que é simplesmente um modo de ser, assim como o decair.

Tese metaética número 14. Algumas teorias éticas tradicionais precisam de virtudes. $O$ Dasein não se prende a qualquer projeto de vida virtuosa, pois que o transcende.

A vida virtuosa apresentar-se-ia como simplesmente um modo pelo qual o Dasein poderia projetar-se, entre outras tantas formas de vida, sem que isso implicasse alguma superioridade ou inferioridade, algum melhoramento. Além disso, nada o prenderia a esse modo de vida, pois que esta poderia ser transcendida a todo o momento; além de que um estado de ânimo fundamental como a angústia poderia retirar o Dasein de um projeto de vida virtuosa projetado em sua cotidianidade. A vida virtuosa pode ser somente um frágil projeto ôntico, visto que na analítica existenciária não há nenhuma indicação do que possa ser algo como uma "vida virtuosa".

Tese metaética número 15. Algumas das teorias éticas tradicionais precisam apelar a um "senso/sentimento moral". O Dasein não pode guiar-se por nenhum "senso moral" empírico, porque os estados de ânimo existenciários, características ontológicas, não fazem qualquer indicação moral, mas apenas abrem para o ser e suas possibilidades.

O Dasein não pode ser determinado por sentimentos subjetivos. Estes se diluiriam em modos da compreensão do Dasein, de sorte que não são fundamentais. Os estados de ânimo, estes sim característicos da abertura do Dasein, não são meros "sentimentos" e nem mesmo podem indicar certos modos específicos de como os entes se apresentam (como agradáveis ou desagradáveis, nos quais se poderiam basear as noções de virtude e de vício). Dessarte, não se derivam dos estados de ânimos virtudes ou vícios, eles não podem constituir, pois, nenhum tipo de "senso" valorativamente direcionado, tal como certo tipo de ética o pretende. 
Tese metaética número 16. Algumas das teorias éticas tradicionais baseiam-se na ideia de contrato. $O$ Dasein não pode ser ético num sentido contratualista, porque não carrega nenhuma propriedade natural (como o "egoísmo") que lhe obrigue a assinar contratos, salvo pela força do medo em um projeto de existência inautêntico (entre tantos outros que se podem realizar por medo), projeto que sempre pode ser transcendido.

O "egoísmo" é simplesmente um modo de ser-com, entre tantos outros efetiváveis pelo Dasein. Nem pode o Dasein ser facilmente determinado em sua reação a algum estado de ânimo. O medo não indica uma forma de agir em específico, de modo que pode tanto diminuir-se pelo temor diante do Estado, como pode reagir a este e buscar sua destruição, temendo ficar nas mãos de uma instituição poderosa; estas são outras tantas possibilidades efetivas. Além disso, o Dasein não tem nem as propriedades nem a estabilidade que the permitiriam assinar contratos, nem poderia se manter definitivamente em um acordo, pois que nada faz com que o Dasein sustente um contrato que não passe pelo crivo da decisão singular. (Nada impede o Dasein assinar um contrato que poderá estar quebrando antes mesmo de acabar de assiná-lo).

Tese metaética número 17. Algumas das teorias éticas tradicionais precisam lançar mão de análise de consequências. O Dasein não pode ser ético num sentido utilitarista por não ser um ente suscetível a cálculo e ponderação de consequências, sem mergulhar em projetos massificadores de uma "maioria" numa existência imprópria.

A ética utilitarista considera o ser humano enquanto um ente calculável e utilizável, na medida em que é concebido como algo a ser levado em consideração nos cálculos das consequências das ações; com isto, limita drasticamente seus projetos, visto que supõe um determinado querer (um determinado projeto) em todos, que seria a felicidade. Assim, nivela o Dasein a um projeto massificador (decaído), que tem por fim algo que se diz (falatório) ser "o que todos querem", e o coisifica na medida em que o considera como ente sujeito a ponderação e cálculo. Mas pelas características vistas nas teses 10 a 13, o Dasein não é previsível no sentido em que uma ética utilitarista de consequências precisa que seja. 
Tese metaética número 18. Algumas das éticas tradicionais precisam da noção de dever. $O$ Dasein não pode ser ético num sentido deontológico tradicional, porque não admite ser descrito como um ser em luta contra as suas paixões e com possibilidade racional sempre disponivel de vencê-las, e na medida em que não lhe é possivel se submeter a qualquer tipo de imperativo - mesmo "autônomo" - que não passe pelo crivo da escolha existenciária, que pode sempre ser ultrapassada por outro projeto.

O dualismo inclinações-razão se dissolve no modo de compreender-se do Dasein, de sorte que não são fundamentais nem determinam seu ser. Portanto, o poder-ser do Dasein não pode ser caracterizado por esse dualismo que supõe que ele seja um ente racional que luta contra suas inclinações; pois seus projetos de ser transcendem tanto as solicitações sensíveis quanto as imposições e limitações da razão. O Dasein é um poderser que se faz a si mesmo singularmente, de forma que nada externo, como deveres éticos ou máximas, o determinam cabalmente; o que ele vai ser passa sempre pelo crivo da escolha de si, que é o projeto singular, e nunca decorrência da observância de deveres e máximas.

Tese metaética número 19. Algumas das teorias éticas tradicionais precisam da noção de pessoa. O Dasein não é pessoa, visto que não se define por propriedades que lhe confeririam algum tipo de dignidade inerente a si próprio.

A noção de pessoa se basearia numa atribuição de dignidade ao ser humano, baseada, às vezes, em propriedades (como a racionalidade ou a fragilidade), outras vezes de maneira mais intrínseca (essa dignidade viria do nascimento, do mero fato de ser um humano). Como o Dasein é um ser histórico (como veremos no próximo conjunto de teses), uma dignidade humana nunca poderá vir por propriedades, mas, em todo caso (se for sequer possível alguma "dignidade" existenciária) através de escolhas e ações históricas de fazer-se a si mesmo; não há nada, como a noção de pessoa, que garanta essa dignidade de maneira a-histórica e prévia. Nesse sentido, a noção de pessoa encobre o ser do humano enquanto poder-ser, que abre para diversas possibilidades de fazer-se, pois a noção de existência que o caracteriza como Dasein justamente aponta para essa abertura que o retira de qualquer "dignidade da pessoa" simplesmente dada. 
(3) Teses metaéticas ligadas à temporalidade.

Tese metaética número 20. A ética tradicional é feita para um ser mortal. Ela não pode ser constituída por um ente que não apenas morre onticamente, mas é para a morte, no sentido de um ente que tem que transformar a sua morte em possibilidade, $e$ não apenas abandonar-se a ou fugir de uma "morte certa" na cotidianidade, um evento que ocorre na existência.

As éticas tradicionais pressupõem uma morte enquanto um evento que aconteceria na vida de todos os seres humanos. Procuram-se regras de convívio para evitar a morte, ou uma vida superior que lide bem com a morte, ou deixar de se perder pensando na morte, ou adquirir uma sabedoria para aceitar a morte, ou seguir uma religião para a qual a morte não é o fim, etc. Mas a morte, no existenciário ser-para-morte, é uma constituição do Dasein; não é um mero evento ôntico que lhe acontece e para o qual caberia preparar-se ou adquirir um saber, mas a sua possibilidade mais própria. As éticas tradicionais, portanto, trabalham com uma compreensão imprópria da morte, que não condiz com o ser-para-morte do Dasein.

Tese metaética número 21. A ética tradicional pressupõe e exige uma temporalidade pública e linear, enquanto o Dasein existelec-siste de maneira projetiva numa temporalidade unitária, circular e sem distinções nítidas entre passado-presentefuturo enquanto distribuições de "agoras".

As teorias éticas tradicionais de um modo geral pressupõem uma compreensão do tempo enquanto público e sequencial. Fazem-se promessas no passado para cumprir no futuro, arrepende-se ou se perdoa por ações realizadas no passado, procura-se fazer cálculos de ações com boas consequências no futuro, ou exigem-se normas universais que valham para todo o tempo. É uma forma niveladora do tempo, que contrasta com a temporalidade originária do Dasein, que consiste no antecipar o futuro na decisão que leva em conta o ter sido, o passado (a facticidade), tudo isso no instante da decisão (presente). A temporalidade do Dasein temporaliza-se na ekstase do futuro, na medida em que é antecipação de projetos; ao passo que o tempo nas éticas tradicionais temporaliza-se no presente, pois que as ações e suas consequências sempre se dão em 
um agora. As éticas tradicionais precisam de um tempo linear e sequencial que encobre a temporalidade originária do Dasein.

Tese metaética número 22. Em decorrência da tese 21, e de grande parte das teses anteriores, pelo fato do Dasein aparecer publicamente como incapaz de cumprir promessas, assumir compromissos, assinar contratos duradouros, agradecer pelo recebido anteriormente, etc., isso não deve levar a considerá-lo como um ser humano "imoral”.

Sendo a temporalidade do Dasein consistente no instante originário da decisão, antecipando projetos e retomando a facticidade, isso significa que o Dasein não pode se pautar pelo tempo enquanto sequência ininterrupta de agoras, temporalidade pressuposta pela ética. De fato, o Dasein no mais das vezes compreende-se a si mesmo no modo de ser do decair, em que o tempo se apresenta enquanto tempo público e sequencial. Porém, a própria existência do Dasein o chama à decisão pelo seu poder-ser fático, em que se apresenta no instante que une o futuro antecipado do projeto e o passado da facticidade retomada na decisão. Assim, o tempo sequencial como que "se distorce", apresentando-se na forma originária da circularidade da decisão, em que as três ekstases (presente, passado e futuro) se veem unidas no instante da decisão, não separadas em uma sequência.

Já que a ética tradicional precisa dessa noção imprópria do tempo para se realizar, em que o Dasein não pode se ajustar completamente, o Dasein vê-se impossibilitado de cumprir plenamente as exigências das éticas tradicionais. Mas isto não significa que ele seja "imoral", porque esta qualificação ainda o manteria dentro da ética tradicional, que foi rejeitada existenciariamente. Deve ser evidente que aquilo que remove da moralidade remove igualmente da imoralidade. O Dasein, simplesmente, conduz a sua existência ontológico-existenciariamente, e não norteado por uma normatividade moral em sentido tradicional, o que não significa que seja vicioso ou desonesto. Referindo-se ao tempo em que o pensamento se transformou em filosofia, Heidegger comenta: “Antes desse tempo, os pensadores não conheciam nem 'lógica' nem 'ética' nem 'física'. Todavia, seu pensamento não era nem ilógico nem imoral. (...) o dizer das 
tragédias de Sófocles conserva e encerra o ethos mais originariamente do que as preleções de Aristóteles sobre a 'ética",207.

${ }^{207}$ HEIDEGGER, Martin. Carta sobre o Humanismo. Op. cit., p. 85. 


\section{CONCLUSÕES}

Já desde o início deste trabalho partimos do fato de que não havia uma ética heideggeriana em sentido tradicional. Dessa forma, nosso propósito não foi adentrar na longa discussão de se existe ou não uma ética (tradicional ou não) implícita na obra de Heidegger. Em vez disso, o que visamos com uma metaética fenomenológicoexistenciária foi procurar mostrar como que a filosofia da existência em Ser e Tempo de Heidegger rejeita, de modo espontâneo, a ética tradicional. Com os resultados obtidos nesta investigação, pudemos mostrar os elementos do pensamento de Heidegger expresso fundamentalmente em Ser e Tempo, uma de duas mais centrais obras, determinantes para que uma ética, em sua concepção tradicional, não possa surgir.

Quando nos propomos pela primeira vez investigar essa possível metaética em Heidegger, não explicitamente presente em seus textos, almejávamos pensar que consequências o baque de um pensamento como o desse filósofo - que procura descontruir a metafísica, questionando a história da filosofia europeia como um todo traria para um campo tão tradicional da filosofia quanto a ética. Sabemos que, se Heidegger problematiza noções tradicionais da metafísica através da aplicação da fenomenologia na investigação ontológica, da diferença ontológica (entre ser e ente) e de uma concepção de humano enquanto Dasein, o ente que compreende o ser, algum impacto isso teria para as teorias éticas desenvolvidas com base nessa metafísica que, tal como Heidegger a compreende, consiste num encobrimento do ser pelo ente. O peso de uma filosofia como a de Heidegger deveria fazer, ao menos, com que não voltemos nosso olhar a essas éticas da maneira fácil e irrefletida habitual, trazendo para essas teorias um olhar metaético de caráter radical que as coloca em risco de não poder se constituir.

Este impacto radical da metaética heideggeriana não afetou, por exemplo, a tradição ética analítica, mas tem tido influência marcante no pensamento "continental". A rejeição fundamental da ética tradicional, quase que espontânea, promovida pelo ponto de vista fenomenológico-existenciário, pode explicar, por exemplo, como o projeto de Sartre - exposto no final da sua obra O Ser e o Nada, de formular uma ética 
em bases existencialistas ficou apenas esboçado em seus Cahiers pour une morale, com textos desconexos e inacabados. Embora pensadores existencialistas, como Albert Camus e Simone de Beauvoir, tenham escrito textos sobre temas morais, nenhum deles sistematizou uma teoria ética. Parece que isso, em vez de uma mera vicissitude histórica, marca a própria impossibilidade de uma ética tradicional numa concepção existenciária do humano. Heidegger, ainda que tenha negado ser um existencialista, lançou as bases para essa corrente de pensamento: a existência enquanto poder-ser fático dificulta de maneira fundamental qualquer empreitada existencialista de fundar uma ética, que parece fadada ao fracasso ou, ao menos, se apresenta como profundamente complexa e dificultosa.

O estudo metaético fenomenológico-existenciário mostrou que qualquer tentativa nesse sentido teria que modificar o método de acesso, a concepção de humano ou a noção de temporalidade, todos estes movimentos conceituais de elevada complexidade. A rejeição da ética tradicional por parte de uma analítica da existência não é, pois, algo de superficial, mas implica estruturas teóricas e práticas fortemente incompatíveis. A questão central, posto em evidência em nosso estudo metaético, foi certamente a questão do humano. Aceitando o "fardo" do "ser-aí" do Dasein e nos distanciando de uma compreensão tradicional de humano como dotado de razão e autonomia, teríamos que repensarmos todas nossas habituais formas de vida, com suas orientações éticas ou políticas que seguem longa tradição, baseada em concepções de humano problematizadas por uma filosofia da existência. Poderemos insistir nessas formas de viver, mas agora plenamente conscientes de elas estarem fundadas no abismo de decisão de um ente que tem de ser seu ser, ente cujo ser está em questão. Essas noções do humano não têm nem a menor chance de poder ser compatibilizadas de algum modo; uma deve desalojar a outra.

Ora, uma rejeição metaética da ética tradicional neste viés fenomenológicoexistenciário não deve necessariamente implicar uma catástrofe no plano ético, por mais que assim o pareça para teorias éticas que assumem a concepção racionalista tradicional do humano. Mas estando dispostos a discutir e questionar essa concepção, poder-se-á ver como, abrindo mão da concepção de humano marcado por propriedades como autonomia e dignidade intrínseca, não nos livramos, de fato, de tentar sustentar algo que nossa existência não suporta. A metaética heideggeriana aponta para uma plena e 
dramática aceitação da finitude. Para quem teme uma catástrofe decorrente dessa metaética, notemos que a vida humana, já sustentada em concepções tradicionais do humano e da ética, está repleta de catástrofes e conflitos, de modo que a problematização da ética tradicional como usualmente a vemos pode significar um convite para assumir outra postura diante de um estado de coisas já problemático. Aceitar a ética como um projeto finito ou procurar outras maneiras de viver pode ser não uma solução paras as penúrias do mundo (obviamente), mas novos modos de enfrentá-las. Não terá sido a analítica existenciária que as introduziu no mundo.

Sabemos que seria ingenuidade pensar que simplesmente poderíamos de imediato mudar a nossa maneira de se viver, de tal modo que condiga com a finitude do Dasein, implicando outras formas de compreender-se que não envolvem a dimensão ética como habitualmente assumida. O mundo continuará com suas agendas que levam em conta, no fundo, uma concepção de humano marcado por propriedades. No entanto, talvez em um bom modo existencialista, poderíamos pensar em novas maneiras de viver com essa nova compreensão existenciária do humano. Podemos desenvolver projetos de existência, singulares "singularíssimos", marcados por essa compreensão que se afasta da estrutura do ético tradicional e assume a finitude do poder-ser. A aceitação da finitude e o dispor-se para a morte, embora pareçam atitudes raramente aconselhadas, aparecem já inclusive num pensador de língua portuguesa como Antônio Vieira, que em seu Sermão de Quarta-feira de Cinza, de 1672, num estilo poético, apresenta o humano como um ser para a morte, como destinado ao pó e, portanto, já, de certa forma, pó ${ }^{208}$. O que Heidegger fez, e a sua metaética colocou claramente, foi mostrar como essa concepção radicalmente finita do humano é incompatível com o movimento da ética tradicional.

Esse baque destrutivo na ética tradicional não implica o fim da ética. Pode-se muito bem buscar novas formas de compreender a ética que confrontam com as bases das éticas tradicionais. O pensamento filosófico contemporâneo, incluso o pensamento ético, procura amiúde confrontar-se com a herança metafísica da tradição filosófica

\footnotetext{
${ }^{208}$ VIEIRA, Antônio. Sermão de Quarta-feira de Cinzas em: Sermões v 1. São Paulo: Edições Loyola, 2008.
} 
europeia $^{209}$. Assim, não se descarta que alguma ética possa lidar razoavelmente bem com as problematizações da metaética heideggeriana. Inclusive, há trabalhos que investigam uma ética no pensamento de Heidegger ${ }^{210}$, mas direcionam-se para um ambiente diverso das éticas tradicionais.

A filosofia de Heidegger provoca um impacto nas estruturas tradicionais de pensamento que ainda estamos descobrindo. Neste trabalho metaético, procuramos estudar qual seria o impacto do pensamento de Ser e Tempo com respeito à ética tradicional, tentando entender claramente os elementos conceituais que o provocam e talvez oportunizar um convite para se pensarem as consequências ainda não aclaradas da filosofia de Heidegger no plano da filosofia prática.

209 Jacqueline Russ fala em uma reformulação da ética (RUSS, Jacqueline. Pensamento ético contemporâneo. São Paulo: Paulus, 1999, p.19).

${ }^{210}$ Como os de Zeljiko Loparic (ver: LOPARIC, Zeljko. Ética e Finitude. São Paulo: Editora Escuta, 2004 e igualmente: Sobre a responsabilidade. Porto Alegre: EDIPUCRS, 2003) e o de Joanna Hodge (HODGE, Joanna. Heidegger e a ética. Trad. Gonçalo Couceiro Cruz. Lisboa: Instituto Piaget, 2000). 


\section{APÊNDICE.}

\section{Poderia uma ética não tradicional evitar a rejeição radical? A ética da afirmação da vida de Friedrich Nietzsche.}

Uma notável ausência na análise das teorias éticas tradicionais foi Nietzsche. Embora conhecido enquanto um crítico da moralidade e da filosofia, pode-se afirmar que ele tem de algum modo uma espécie de ética, na medida em que ele apresenta um critério para a caracterização das ações humanas que leva em conta a noção de vida e que o distanciaria das demais teorias éticas que ele critica, e que chamamos tradicionais. Ora, realizamos neste trabalho uma análise metaética dessas éticas tradicionais, que foram rejeitadas pela analítica existenciária de Heidegger; mas se uma suposta ética de Nietzsche pode ser considerada como não tradicional, ao afirmamos que Nietzsche se distancia criticamente dessas outras éticas, poderia ela evitar a rejeição radical? É o que investigaremos brevemente a seguir.

Em primeiro lugar, que traço distintivo esta ética nietzschiana poderia alegar para poder ser considerada como não tradicional? Nietzsche empreende uma peculiar investigação acerca de categorias muito caras à tradição filosófica, como "bom", "mau" e "verdade". Observamos, na exposição das teorias éticas tradicionais, que valores como "bom", "mau", "correto" e "incorreto" são fortemente afirmados, embora possam divergir acerca do que esses termos representam, já que cada teoria tem uma noção própria dessas noções. O ponto que temos de destacar está no fato de que Nietzsche não quer simplesmente trazer uma "contribuição" ao debate acerca do que seja o "bem" ou "verdadeiro". Em vez de entrar no jogo filosófico e procurar trazer sua a própria noção do "bom" e do "mau", colocando-a ao lado das outras, a desconfiança nietzschiana lança seu olhar sobre o "valor" mesmo desses "valores", um valor que ele procura julgar desde o ponto de vista da vida, e não desde um patamar além da vida. Assim, o núcleo da diferença entre o pensamento de Nietzsche e as teorias éticas tradicionais consiste em que esse filósofo está interessado em ver "sob que condições o homem inventou para si os juízos de valor 'bom' e 'mau”, inquirir sobre "que valor têm eles"; ou seja, investigar se esses valores inventados por esse humano, demasiado humano, são 
“indício de miséria, empobrecimento, degeneração da vida" ou se encontramos neles "a plenitude, a força, a vontade da vida, sua coragem, sua certeza, seu futuro" ${ }^{211}$.

Essa questão nietzschiana é acerca da ascensão ou decadência dos impulsos vitais, e seu uso na avaliação da moralidade. E podemos já adiantar que as teorias éticas (e a filosofia europeia de um modo geral), segundo o diagnóstico de Nietzsche, negam a vida. "Em todos os tempos, os homens mais sábios fizeram o mesmo julgamento da vida: ela não vale nada [...]. Sempre, em toda parte, ouviu-se de sua boca o mesmo tom - um tom cheio de dúvida, de melancolia, de cansaço da vida, de resistência à vida" ${ }^{212}$. Porém, o que significa afirmar ou negar os impulsos da vida? A resposta a essa pergunta está ligada à noção de "vontade" em Nietzsche. Nietzsche enxerga na palavra "vontade" uma complexidade, da qual surgem diversos sentidos para o termo, entre eles o de sensação, de pensamento (ter consciência do que se quer) e de um afeto de comando. $\mathrm{O}$ último sentido, vontade enquanto afeto, é o que representa o aspecto mais forte da vontade. É no aspecto afetivo da vontade, num páthos, que se encontra a chave para se compreender a vontade ${ }^{213}$. Ele é o que se costuma associar às "sensações de coação, sujeição, pressão, resistência, movimento que normalmente tem início logo após o ato da vontade"214; é uma “intensidade" que se sobrepõe ao sentir e ao pensar (os outros sentidos de vontade). Nietzsche vê, assim, a vontade como estando em direção ao poder, à potência, em suma, como uma vontade de poder ${ }^{215}$.

Quando, então, Nietzsche procura pensar a moral sob o ponto de vista da vida, procura investigar a vontade de poder atuante, que pode ser afirmativa ou negativa (ou seja, afirma ou nega os impulsos vitais). Os diversos impulsos, que se tornam diversos quereres distintos e até opostos, têm uma mesma natureza, a qual consiste na vontade de poder. Os impulsos, num processo de transfiguração, são emasculados ou sublimados ${ }^{216}$; por exemplo, podemos transformar esse impulso em arte ou negá-lo numa vida de privações, entre outras possíveis formas de transfiguração que os

\footnotetext{
${ }^{211}$ NIETZSCHE, Friedrich. Genealogia da Moral. Uma Polêmica. Trad. Paulo César de Souza. São Paulo: Companhia das Letras, 2009, p. 9 (§3).

${ }^{212}$. Crepúsculo dos Ídolos, ou, Como se filosofa com o Martelo. Trad. Paulo César de Souza. São Paulo: Companhia das Letras, 2006, p. 17 (II, §1).

${ }^{213}$ SAMPAIO, Evaldo. Por que somos decadentes? Afirmação e negação da vida segundo Nietzsche. Brasília: Editora Universidade de Brasília, 2013, p. 227.

${ }_{214}^{214}$ NIETZSCHE, Friedrich. Além do bem e do mal. (§19). Apud SAMPAIO, Evaldo. op. cit., p. 228.

${ }^{215}$ SAMPAIO, Evaldo. op. cit., p. 228.

${ }^{216}$ SAMPAIO, Evaldo. Op. Cit., p. 190-191.
} 
impulsos podem tomar em nossa existência. Em suma, em qualquer expressão de nossa vida, nossas atividades, nossas ideias e valores, têm-se subjacentes impulsos vitais, que se transfiguram, assumindo diversas formas. Nos valores morais jazem exigências fisiológicas de uma determinada forma de vida, em que impulsos dominantes sobressaem-se em relação a outros. A investigação nietzschiana quer procurar detectar os "preconceitos morais", ou seja, quais os impulsos que dominam e as paixões que se enfraquecem, em vista de saber qual vontade de poder está atuando numa certa hierarquia de valores, para assim fazer seu julgamento extramoral: verificar se há ali uma afirmação ou uma negação da vida. "[...] necessitamos de uma crítica dos valores morais, o próprio valor desses valores deverá ser colocado em questão",217.

Dessarte, em seu livro Genealogia da moral, em que procura mostrar a origem de algumas noções da moralidade como "bom" e "mau", "culpa" e "ascetismo" numa espécie de análise fisiológico-histórica que verifique quais impulsos vitais precisaram afirmar determinados sentidos a esses termos, Nietzsche não só procura determinar quais são esses impulsos, como os avalia segundo o critério da afirmação ou negação da vida. Com esse critério, questiona o valor dessas noções morais, valor que costuma ser tomado como algo dado. Ora - ele se pergunta - será que devemos mesmo seguir o bem e fugir do mal? Essa pergunta, que muitos responderiam com um invariável "sim", fica mais problematizada quando notamos que esses valores estão fundados, na verdade, em impulsos vitais, em vez de terem um valor "em si mesmos".

Tomava-se o valor desses 'valores' como dado, como efetivo, como além de qualquer questionamento; até hoje não houve dúvida ou hesitação em atribuir ao 'bom' valor mais elevado que ao 'mau', mais elevado no sentido da promoção, utilidade, influência fecunda para o homem (não esquecendo o futuro do homem). E se o contrário fosse a verdade? E se no 'bom' houvesse um sintoma regressivo, como um perigo, uma sedução, um veneno, um narcótico, mediante o qual o presente vivesse às expensas do futuro? Talvez de maneira mais cômoda, menos perigosa, mas também num estilo menor, de que jamais alcançasse o supremo brilho e potência do tipo homem? De modo que precisamente a moral seria o perigo entre os perigos?... ${ }^{218}$

\footnotetext{
${ }^{217}$ NIETZSCHE, Friedrich. Genealogia da Moral. Uma Polêmica. Op. cit., p. 12 (§6).

${ }^{218}$ Idem.
} 
O diagnóstico de Nietzsche é que a filosofia, desde seu princípio com Sócrates, é sinal de decadência dos impulsos vitais. Como que os filósofos negaram a vida? Resposta: ao negarem esse conflito eterno entre vontade de poder de distintas direções, o devir, do qual a vida se constitui. Vimos, por exemplo, na nossa exposição das teorias éticas tradicionais, que Kant, fazendo a distinção entre o mundo inteligível e o mundo sensível, vê neste as nossas inclinações e naquele o nosso lado racional, e funda a ética justamente nesse lado inteligível. O devir das inclinações, podemos interpretar assim, deve ser superado pela constância da racionalidade, que postula leis universais para si mesma. Schopenhauer, uma das principais influências de Nietzsche, enxerga a mudança, os conflitos e a discórdia interna da vontade, mas concebe uma conciliação, uma harmonia nas Ideias, de modo que Schopenhauer, como é a tendência geral da filosofia, acaba submetendo o devir ao eterno.

Tudo o que os filósofos manejaram, por milênios, foram conceitos-múmias; nada realmente vivo saiu de suas mãos. Eles matam, eles empalham quando adoram, esses idólatras de conceitos - tornam-se um perigo mortal para todos, quando adoram. A morte, a mudança, a idade, assim como a procriação e o crescimento, são para eles objeções - até mesmo refutações. $\mathrm{O}$ que é não se torna; o que se torna não $e^{219}$.

O devir é uma aparência em Schopenhauer. A vontade de poder de Nietzsche se aproxima da vontade de vida de Schopenhauer, mas sem essa reconciliação no plano das Ideias imutáveis. Nietzsche, com a sua noção de vontade de poder, afirma o devir, não como uma aparência que esconde a Coisa em si (a verdadeira realidade por trás das aparências, do devir), mas como o próprio sentido da realidade. É o conflito, a mudança, a geração, a corrupção, em suma, o que nos aparece, a mudança em si mesma, sem o "lastro da eternidade" - isso tudo é a vontade de poder. E se se analisam a morfologia e a evolução da vontade de poder, desenvolve-se uma teoria das "relações de dominação" que perfazem o "fenômeno vida", em que há ascensão e decadência dos impulsos vitais $^{220}$.

Nietzsche, com sua atitude de pessimismo trágico, vê o ímpeto para destruição enquanto uma força vital, como um estímulo à vida, em vez de um ímpeto a ser

\footnotetext{
219 $\$ 1)$. Crepúsculo dos Ídolos, ou, Como se filosofa com o Martelo. Op. cit., p. 25 (III, ${ }^{220}$ SAMPAIO, Evaldo. op. cit., p. 237.
} 
destruído para apaziguar ou extinguir a dor, como aconteceria, segundo seu diagnóstico, nos pessimistas românticos (incluso Schopenhauer). Nietzsche procura afirmar o devir. Todas aquelas características atribuídas ao "Ser" - eternidade, imutabilidade, identidade - são, na verdade, características do não-ser, do nada, visto que o que vemos é o devir. Dessa forma, Nietzsche vê que o que provocou essa visão foi uma vontade niilista, que está por traz de tudo que se concebeu como valioso e superior, que se refere ao Ser, ou melhor, ao nada. Rejeitar essa vontade niilista é, portanto, uma "suprema afirmação da vida", que é, precisamente, o impulso de todo o pensamento nietzschiano ${ }^{221}$. Assim, aproximamo-nos ao que seria uma afirmação da vontade de poder: a afirmação do devir, da mudança, da criação e da destruição, do crescimento e do desfalecimento, do conflito dos quereres, tudo isso que constitui a realidade.

É nessa afirmação da vontade de poder e na crítica à negação do devir, que é a vida, que Nietzsche chega finalmente à crítica da moral cristã, a moral vigente que institui o que é bom e benévolo. Nietzsche a vê como "decadente", visto que essa moral julga como "bom" aquilo que consiste em uma "debilidade e extirpação dos impulsos vitais", tendo por fim "a domesticação ou supressão do que nos aflige" e valorizando as condutas que "favorecem o enfraquecimento e a autoexaustão" 222 . Nesse sentido, Nietzsche se autointitula um "imoralista", pois vai de encontro a essa moral vigente; nega a moral cristã e aquilo que esta julga como bom, pois que são sintomas de decadência ao não querer lidar com a dor, mas tenta eliminá-la ou negá-la.

Para afirmar o devir (em suma, a vontade de poder), é preciso evitar toda "fraqueza sentimental" que nos impele a valorar a vida em si mesma, ou seja, dar um valor à vida, o que poderia fazer com que a violência, a destruição etc. mostrassem-se como algo "injusto", pois que na verdade a própria vida atua destruindo, violentando. É preciso ver o que ela mostra por si mesma. A vida se mostra como um expandir-se, crescer, dar "vazão a sua força". Não deve ser confundido com um ímpeto à autopreservação, pois que este é apenas uma consequência indireta da expansão vital; a autopreservação como um princípio pode ser uma negação da vida, na medida em que a expansão, a potência vital pode levar mesmo ao próprio sacrifício. Também a utilidade não pode ser um princípio, pois que a inutilização, a atrofia etc. podem ser postas à

\footnotetext{
${ }^{221}$ Ibidem, p. 240.

222 Ibidem, p. 242.
} 
serviço da afirmação da vida. E, por último, afirmar a vida não significa a busca pelo prazer ou pela diminuição da dor, pois que é, na verdade, a aquisição do que buscamos que pode trazer prazer ou diminuição da dor. Em suma, antes de uma autopreservação, utilidade ou busca de prazer ou apaziguamento da dor, está o poder, a potência, ou melhor, a vontade de poder $^{223}$.

As valorizações nietzschianas procuram ir a encontro da vida. Sendo esta vontade de poder, como foi apresentado, então suas valorizações têm que levar em conta a afirmação da vontade de poder. Assim, nesta revaloração de Nietzsche, o bom é tudo aquilo que "eleva o sentimento de poder, a vontade de poder, o próprio poder no homem"; o mau é tudo o "que vem da fraqueza"; e a felicidade é o "sentimento de que o poder cresce, de que uma resistência é superada" ${ }^{224}$. Portanto, o que diferencia, segundo Nietzsche, a "moral do cultivo" (aquela que vai a encontro dos impulsos vitais e os transforma em potência) e a "moral da domesticação" (que procura extirpar os instintos, o que Nietzsche enxerga no cristianismo) é justamente o fato de na primeira as noções de bem e mal favorecem o "crescimento" e o "vigor de sua existência", que ascende os impulsos vitais, enquanto na segunda vão em direção à "degeneração e à veleidade dos homens" ${ }^{225}$, que diminui os impulsos vitais. Em suma, sob a ótica da vida, a primeira é ascendente e a segunda é decadente.

Agora podemos delinear melhor a diferença entre as éticas tradicionais apresentadas neste trabalho e a que podemos chamar ética nietzschiana. Como afirmamos acima, Nietzsche se preocupa, num primeiro momento, em investigar que impulsos levam à afirmação de determinadas ideias e valores (como as da moralidade) para, num segundo momento, julgá-los do ponto de vista da vida. Segundo Nietzsche, a história da filosofia é marcada por essa negação dos instintos vitais, da vontade de poder, do devir e, portanto, são manifestações da decadência. As éticas tradicionais que expomos, enquanto parte da história da filosofia, podem também estar nessa linha da negação da vontade de poder. Vemos que em Kant se procura fundamentar a ética no inteligível, numa boa vontade que autolegisla leis universais que devem ser seguidas independentemente do que as inclinações empíricas indiquem. O contrato social de

\footnotetext{
${ }^{223}$ Ibidem, p. 239.

${ }^{224}$ NIETZSCHE, Friedrich. O Anticristo (§2) apud. SAMPAIO, Evaldo. Op. Cit., p. 244.

${ }^{225}$ SAMPAIO, Evaldo. Op. Cit., p. 244.
} 
Hobbes nada mais é que o apaziguamento dos impulsos humanos por parte do Estado. Uma vida superior em Aristóteles consiste na contemplação dos entes eternos, que são superiores que os entes marcados pelo devir. Em suma, as éticas filosóficas tradicionais, como a própria filosofia, são todas, no diagnóstico nietzschiano, sintomas de decadência.

Uma ética nietzschiana, pelo contrário, seria aquela que procuraria afirmar a vida, a vontade de poder, o devir. Porém, o que é esse devir? Seria o conflito entre vontades, a dor, o crescimento, o envelhecimento, a força, a guerra. Assim, embora o pensamento moral de Nietzsche não implique a destruição do outro ou uma espécie de inversão do que as éticas tradicionais estipulam como o correto, nada impede que, para a realização da potência, muitos dos atos costumeiramente criticados pelas éticas sejam realizáveis. Como a vontade de poder se transfigura, não há uma determinação forte de qual ação se deve ou não realizar. "Há um ódio à mentira e à dissimulação que vem de uma sensível noção de honra; há um ódio igual que vem da covardia, sendo a mentira proibida por um mandamento divino. Covarde demais para mentir" ${ }^{, 26}$. Ou seja, uma mesma atitude (ódio à mentira) pode manifestar uma potência, força (a honra), ou covardia, fraqueza.

Embora não haja fortes indicações para a ação, Nietzsche afirma a existência de tipos superiores de homens, tipos elevados que se destacam da humanidade por seu espírito de potência. Um personagem histórico que foi considerado por Nietzsche um tipo da ascensão da vida foi César Bórgia ${ }^{227}$, político do período da Renascença, cuja astúcia política inspirou Maquiavel em O Príncipe. Ora, ele foi um indivíduo que teve de matar, mentir, enganar etc., ou seja, que realizou ações que as teorias éticas tradicionais condenariam. No entanto, na ética de Nietzsche, ele indicaria para um tipo superior de pessoa.

Com essas diferenças em relação as demais éticas apresentadas, é possível que consideremos essa ética nietzschiana como sendo não-tradicional. Se ela, por conseguinte, se destacaria nitidamente diante das outras teorias éticas, será que ela poderia passar ilesa pelos mecanismos de rejeição radical a partir da analítica

\footnotetext{
${ }^{226}$ NIETZSCHE, Friedrich. Crepúsculo dos Ídolos, ou, Como se filosofa com um Martelo. Op. cit., p. 14 $(\mathrm{I}, \S 32)$

227 Ibidem, p. 85 (IX, §37).
} 
existenciária de Heidegger? Como início de resposta, podemos lembrar da bastante conhecida tese heideggeriana de que Nietzsche seria o último metafísico e, portanto, que a sua filosofia traria também, como as outras, um encobrimento do ser pelo ente, por um ente chamado vontade de poder, que operaria como uma espécie de princípio que novamente toma o lugar do ser, na medida em que se afirma: tudo é vontade de poder. Isto já pareceria indicar uma rejeição heideggeriana de uma ética nietzschiana, no sentido antes delineado. Porém, é conveniente mostrarmos de maneira mais pormenorizada como esta ética de Nietzsche poderia ser rejeitada pela analítica de Heidegger.

Voltemos para a noção de vida. Vida e existência, ainda que no cotidiano por vezes empreguemos como sinônimos, são conceitos bastante distintos. A existência, em Heidegger, tem a ver com a abertura ao ser do Dasein: o Dasein é aberto "aí" ao ser dos entes e, assim, compreende e projeta suas possibilidades. O Dasein é este poder-ser, pois que é sempre aberto ao desvelamento do ser e, com isso, projeta-se em diversas possibilidades. Isso se diferencia de uma noção de vida, principalmente no sentido nietzschiano. Qualquer conotação de determinação natural (biológica) que a vida possa ter - como ímpeto, expansão, etc. - não é fundamental com respeito ao "ser-aí" que a existência expressa, segundo Heidegger, no modo de ser do Dasein. Qualquer tipo de determinação natural haveria de passar ainda pelo crivo da existência; não é, pois, uma fatalidade, já que o poder-ser da existência pode lidar com as determinações naturais das mais diversas formas, o que significa que não são determinações, na medida em que elas passam pelo critério existenciário do poder-ser.

Mas pareceria haver uma confluência entre ambos pensadores no que se refere ao devir. No caso de Nietzsche, a vida é este conflito de vontades de poder que resulta em crescimento, declínio, força, mudança, destruição etc., em suma, o devir. Ora, se poderia dizer que o devir é também, em certo sentido, característico da existência, dado que o poder-ser do Dasein marca a inconstância da existência. Quando Heidegger afirma que a essência do Dasein consiste na existência, ele, contrariando a tendência da tradição filosófica, entende-a enquanto uma indeterminação. Essência, ao invés de uma propriedade constante, imutável, que faz com que um ente seja o que é, consiste na abertura para possibilidades que é própria da existência. Existência, enquanto essência do Dasein, nada mais é do que ter-de-ser a todo o momento e, nesse sentido, seria devir, 
mudança. Contudo, esse devir existenciário distingue-se do nietzschiano, pois que não pode ser compreendido como resultado de diversos impulsos vitais que querem expressar potência. Como dissemos, o Dasein não é refém da natureza ou de qualquer tipo de determinação externa, de modo que o Dasein não pode se ver acuado diante de algo como a vontade de poder, nem mesmo por uma multiplicidade de vontades de poder.

Outra aparente coincidência se daria no plano da criação de valores. O Dasein, fundamentalmente, compreende os entes em seu lidar, de modo que a criação de valores está relacionada com essa lida. O Dasein tem, entre os modos existenciais de compreender-se em meio aos entes, a criação de valores. Porém, a criação existenciária de valores não pode significar apenas a afirmação de determinada forma de vida, seja ela "decadente" ou "ascendente". Mais fundamental que a afirmação de um modo de vida é a compreensão dos entes em que a geração de valores se sustenta. Enquanto uma forma existencial (ôntica) de compreensão, os valores simplesmente poderiam não ser criados sem que isso tenha interferência no desvelamento do ser dos entes; este ainda se daria, mas sem a relação meramente ôntica a valores. É certo que na compreensão, os entes originariamente se apresentam ao Dasein com um sentido, porém isso significa somente que o ente se apresenta enquanto algo (por exemplo, a mesa se apresenta enquanto mesa, e não como cadeira), o que não tem uma relação intrínseca com o valor. O sentido dos entes não implica um sentido valorativo, nem, especificamente, moral.

Os valores de "ascendência" e "decadência" para Nietzsche podem ser vistos como uma espécie de valores "mais fundamentais". Enquanto os humanos, em seu viver, criam valores, estes ainda podem ser avaliados como mais ou menos fundamentais na medida em que afirmem ou neguem os impulsos vitais. Em Heidegger, no entanto, não há critérios para se distinguir entre valores ascendentes e decadentes, superiores ou inferiores. Em primeiro lugar, como já notamos, os impulsos vitais não seriam determinantes nem fundamentais para a existência. A vontade de poder é apenas um ente, de modo que o ser, embora possa se desvelar dessa forma, não se limita nem se reduz a esta, sendo assim que a vontade de poder não é nem pode ser algo de fundamental. Além disso, como vimos, o Dasein não poderia se ver como um eixo perpassado de diversas vontades de poder, visto que elas não são determinantes suas, mas, pelo contrário, elas devem antes passar pelo crivo da existência. Se o ser não é 
determinado pela vontade de poder, tampouco o Dasein, como abertura ao ser, terá tal determinação; por isso, não faz sentido avaliar seus modos de fazer-se a partir da afirmação ou negação da "vontade de poder".

Além disso, o método fenomenológico de Heidegger já inicialmente elimina qualquer critério de valoração, mesmo o "valor dos valores" e mesmo a "transvaloração" nietzschiana (a inversa de uma valoração, é ainda uma valoração). Por isso, não pode se apresentar na fenomenologia do Dasein alguma ascendência ou decadência em termos de vida. O decair do Dasein não é o mesmo que a vida decadente apontada por Nietzsche ${ }^{228}$. Enquanto em Nietzsche decadência é uma forma de valoração segundo um critério vital (negação da vida), o decair em Heidegger é uma dimensão do ser do Dasein, sem nenhuma conotação valorativa. Representa apenas que o Dasein se vê no mais das vezes preso em suas ocupações no mundo-ambiente, compreendendo-se nas possibilidades da cotidianidade mediana. Tanto a ascensão ou a decadência dos impulsos vitais podem ser modos ônticos do decair mais fundamental. A produção das tragédias entre os gregos antigos (afirmação da vida na forma da arte, segundo Nietzsche) ou o cumprimento da moral cristã (negação da vida) podem ser modos do fazer-se existenciário na cotidianidade mediana; produz-se arte como se produz, segue-se a moral porque se segue; e também podem ser possibilidades autênticas da existência. Ou seja, o decair de Heidegger e a decadência de Nietzsche são formas de visualização do humano completamente distintas.

A ascendência e a decadência em Nietzsche, mesmo sendo anteriores às habituais valorações das teorias éticas tradicionais, fornecem de algum modo critérios do "bom" e do "mau". Afirmar a vontade de potência seria um bem, ao passo que sua negação seria um mal. Isso não pode se mostrar na simples fenomenologia dos modos de ser aplicada em Ser e Tempo. Qualquer tipo de critério que determine algum bem ou mal, certo ou incorreto, mesmo no contexto do pensamento nietzschiano, que se distancia tão radical e criticamente das teorias éticas habituais (pois que se trataria aqui de um bem e de um

\footnotetext{
${ }^{228}$ Normalmente Nietzsche emprega o termo francês décadence referindo-se ao que denominamos "decadência", mas também por vezes utiliza termos alemães como Verfall e Niedergang (ver nota do tradutor em: NIETZSCHE, Friedrich. Crepúsculo dos Ídolos, ou, Como se filosofa com um Martelo. Op. cit., p. 115). Na tradução que utilizamos de Ser e Tempo, o termo em português "decair" refere-se ao termo Verfallen do alemão, de modo que se vê uma aproximação do termo nietzschiano com o heideggeriano: ambos poderiam ser traduzidos por "decadência". No entanto, claramente isso não implica uma aproximação dos conceitos, que são distintos em cada autor.
} 
mal anteriores aos da ética tradicional, na medida em que levam em conta os impulsos vitais, enquanto os éticos tradicionais já seriam resultados desses impulsos), não cabe na fenomenologia de Heidegger. Nesse sentido, teria razão Heidegger ao considerar Nietzsche como um metafísico. Portanto, somos da opinião de que mesmo uma ética não tradicional na linha nietzschiana seria rejeitada pela analítica existenciária de Heidegger na base dos argumentos apresentados. 


\section{BIBLIOGRAFIA}

\section{Textos de Heidegger:}

HEIDEGGER, Martin. O Conceito de Tempo. Trad. Marco Aurélio Werle. em: Cadernos de Tradução. No 2, 1997, p. 7-39.

. Os Conceitos fundamentais da Metafísica: Mundo - Finitude-

Solidão. Trad. Marco Antônio Casanova. Rio de Janeiro: Forense Universitária, 2006. . Carta sobre o Humanismo. Trad. Emmanuel Carneiro Leão

Rio de Janeiro: Tempo Brasileiro, 2009. . Ser e Tempo. Trad. Márcia S. C. Schuback. Petrópolis: Vozes, 2011. . Ser e Tempo. Trad. Fausto Castilho. Campinas: Editora Unicamp; Petrópolis: Vozes, 2012.

\section{Outros textos:}

ARISTÓTELES. Ética a Nicômaco. Trad. António de Castro Caeiro. São Paulo: Atlas, 2009.

BROCHARD, Victor. A Moral Antiga e a Moral Moderna. Em: Cadernos de Ética e Política 8, 1/2006.

COITINHO, Denis. Éticas Neocontratualistas em: TORRES, João C. B. (org.). Manual de Ética. Questões de ética teórica e aplicada. Petrópolis: Vozes; Caxias do Sul: Universidade de Caxias do Sul; Rio de Janeiro: BNDES, 2014.

COMTE-SPONVILlE, André. Pequeno Tratado das Grandes Virtudes. São Paulo: Martins Fontes, 2012.

DALL'AGNOL, D. ; DUTRA, D. J. V. ; BORGES, M.L. . O que você precisa saber sobre Ética. 1 ${ }^{\text {a }}$. ed. Rio Janeiro: DP\&A, 2002.

EPICURO, Máximas Principais, XVI, apud LAÊRTIOS, Diógenes. Vidas e Doutrinas dos Filósofos Ilustres. Brasília: Editora UnB, 2008.

HOBBES, Thomas. Do Cidadão. São Paulo: Martins Fontes, 2002a. . Os Elementos da Lei Natural e Politica. São Paulo: Ícone, 2002b. 
HODGE, Joanna. Heidegger e a ética. Trad. Gonçalo Couceiro Cruz. Lisboa: Instituto Piaget, 2000.

HUME, David. Tratado da Natureza Humana. São Paulo: Editora Unesp, 2009.

HUSSERL, Edmund. Ideias para uma Fenomenologia Pura e para uma Filosofia Fenomenológica. Trad. Márcio Suzuki. São Paulo: Ideias \& Letras, 2006.

HUTCHESON, Francis. Ensaio sobre a natureza e conduta das paixões e afecções em: BUTLER, Joseph [et al] Filosofia moral britânica. Textos do século XVIII. Trad. Álvaro Cabral. $2^{\mathrm{a}}$ ed. Campinas: Editora Unicamp, 2013.

DAVIS, Zachary \& STEINBOCK, Anthony. Max Scheler. 2014. Disponível em: http://plato.stanford.edu/entries/scheler/ Acessado em 30 de agosto de 2015.

KANT, Immanuel. Fundamentação da Metafísica dos Costumes. Trad. Paulo Quintela. Lisboa: Edições 70, 2008.

LOPARIC, Zeljko. Ética e Finitude. São Paulo: Editora Escuta, 2004. . Sobre a responsabilidade. Porto Alegre: EDIPUCRS, 2003.

MANDEVILLE, Bernard. Uma investigação sobre a origem da virtude moral em: BUTLER, Joseph [et al] Filosofia moral britânica. Textos do século XVIII. Trad. Álvaro Cabral. $2^{\mathrm{a}}$ ed. Campinas: Editora Unicamp, 2013.

MENDONÇA, Wilson. Questões metaéticas em: TORRES, João C. B. (org.). Manual de Ética. Questões de ética teórica e aplicada. Petrópolis: Vozes; Caxias do Sul: Universidade de Caxias do Sul; Rio de Janeiro: BNDES, 2014.

MILL, Stuart. Utilitarismo. Trad. F. J. Azevedo Gonçalves. Lisboa: Gradiva, 2005.

NAHRA, Cinara. O Consequencialismo em: TORRES, João C. B. (org.). Manual de Ética. Questões de ética teórica e aplicada. Petrópolis: Vozes; Caxias do Sul: Universidade de Caxias do Sul; Rio de Janeiro: BNDES, 2014.

NERI, Demetrio. Filosofia Moral. São Paulo, Edições Loyola, 2004.

NIETZSCHE, Friedrich. Crepúsculo dos Ídolos, ou, Como se filosofa com o Martelo. Trad. Paulo César de Souza. São Paulo: Companhia das Letras, 2006. . Genealogia da Moral. Uma Polêmica. Trad. Paulo César de Souza. São Paulo: Companhia das Letras, 2009.

PAVIANI, Jayme; SANGALLI, Idalgo J. Ética das Virtudes em: TORRES, João C. B. (org.). Manual de Ética. Questões de ética teórica e aplicada. Petrópolis: Vozes; Caxias do Sul: Universidade de Caxias do Sul; Rio de Janeiro: BNDES, 2014.

RUSS, Jacqueline. Pensamento ético contemporâneo. São Paulo: Paulus, 1999. 
SAMPAIO, Evaldo. Por que somos decadentes? Afirmação e negação da vida segundo Nietzsche. Brasília: Editora Universidade de Brasília, 2013.

SCHELER, Max. Para a Reabilitação da Virtude em: Da Reviravolta dos Valores. Trad. Marco Antônio Casanova, 2ed. Petrópolis: Vozes, 2012.

SCHOPENHAUER, Arthur. O Mundo como Vontade e como Representação. Tomo I. Trad. Jair Barboza. São Paulo: Editora UNESP, 2005.

SLOTE, Michael. Virtues Ethics em: SKORUPSKI, John (Ed) The Routledge Companion to Ethics. Nova Iorque, Routledge, 2010.

SOKOLOWSKI, Robert. Introdução à Fenomenologia. São Paulo: Edições Loyola, 2004.

STEIN, Ernildo. Compreensão e Finitude. Estrutura e movimento da interrogação heideggeriana. Ijuí: Editora Unijuí, 2001.

. Pensar e Errar. Um ajuste com Heidegger. Ijuí: Editora Unijuí, 2011.

VATTIMO, Gianni. Introdução a Heidegger. Lisboa: Instituto Piaget, 1996. 